Gisele Pereira de Souza

\title{
LINGUAGEM DE ESPECIALIDADE DA CIÊNCIA DA INFORMAÇÃO: ESTUDO EXPLORATÓRIO A PARTIR DOS PERÍODICOS BRASILEIROS DA ÁREA ENTRE 2005 E 2009
}


Gisele Pereira de Souza

\section{LINGUAGEM DE ESPECIALIDADE DA CIÊNCIA DA INFORMAÇÃO: ESTUDO EXPLORATÓRIO A PARTIR DOS PERÍODICOS BRASILEIROS DA ÁREA ENTRE} 2005 E 2009

Dissertação de mestrado apresentada ao Programa de Pós-Graduação em Ciência da Informação, área de concentração, Cultura e Informação, linha de pesquisa Organização da Informação e do Conhecimento, da Escola de Comunicações e Artes da Universidade de São Paulo, como exigência para obtenção do título de Mestre em Ciência da Informação.

Orientador: Profa. Dra. Johanna Wilhelmina Smit 


\section{FICHA CATALOGRÁFICA}

Autorizo a reprodução e divulgação total ou parcial deste trabalho, por qualquer meio convencional ou eletrônico, para fins de estudo e pesquisa desde que citada à fonte.

Catalogação na publicação
Serviço de Biblioteca e Documentação
Escola de Comunicações e Artes da Universidade de São Paulo
Souza, Gisele Pereira de
Linguagem de especialidade da Ciência da Informação: estudo
exploratório a partir dos periódicos brasileiros da área entre 2005 e 2009 /
Gisele Pereira de Souza - São Paulo : G. P. Souza, 2011.
104 p.
Dissertação (Mestrado) - Escola de Comunicações e Artes /
Universidade de São Paulo.
Orientadora: Prof. ${ }^{\text {a Dr. }}{ }^{a}$ Johanna Wilhelmina Smit
1. Ciência da informação 2. Terminologia 3. Linguagem de especialidade I.
Smit, Johanna Wilhelmina II. Título
CDD 21.ed. - 401.4




\section{TERMO DE APROVAÇÃO}

Nome do Autor: Gisele Pereira de Souza

Título da Dissertação: Linguagem de especialidade da Ciência da Informação: estudo exploratório a partir dos periódicos brasileiros da área entre 2005 e 2009.

Dissertação de mestrado apresentada ao Programa de Pós-Graduação em Ciência da Informação, área de concentração, Cultura e Informação, linha de pesquisa Organização da Informação e do Conhecimento, da Escola de Comunicações e Artes da Universidade de São Paulo, como exigência para obtenção do título de Mestre em Ciência da Informação.

Orientador: Profa. Dra. Johanna Wilhelmina Smit

\section{BANCA EXAMINADORA}

Prof. Dr.

Instituição:

Prof. Dr.

Instituição:

Prof. Dr.

Instituição:

Aprovado em:

São Paulo, 


\section{AGRADECIMENTOS}

Aos meus familiares, amigos, colegas de trabalho, e a todos que compartilharam comigo os últimos anos, observando minha vontade de aprender sempre mais e compartilhar tudo que sei.

À toda equipe da ABERJE- Associação Brasileira de Comunicação Empresarial, pela compreensão de minhas ausências em função das aulas e pesquisa, e em especial ao Prof. Dr. Paulo Nassar por todo estímulo acadêmico e intelectual.

À minha amiga, Nara, pelas conversas inspiradoras e pela revisão deste trabalho.

Ao meu namorado, Thiago, por me compreender, amparar meu choro, me trazer à realidade e me incentivar a nunca desistir da minha vontade de ensinar.

À minha tia, Helyane, que sempre me inspirou a trabalhar e viver com paixão e me mostrou que a Biblioteconomia pode mudar realidades. Sua força e determinação sempre me surpreenderam!

À minha mãe, Gislaine, por todos os momentos de amparo e pelo amor incondicional, amplo e irrestrito. Por tolerar minhas mudanças de humor, compreender minhas inconstâncias, e por apoiar, de todas as formas, as minhas mais diversas escolhas.

À minha orientadora, Johanna, que sofreu com minhas ausências, com minhas dúvidas e medos, mas soube com total maestria coordenar tudo isso e dar um rumo mais apropriado a esse estudo. Sua delicadeza ao tratar das minhas lacunas, sua precisão nas observações e sua compreensão das minhas limitações tornaram possível a finalização desse trabalho. Minha eterna gratidão pelo presente de poder ter compartilhado de seu conhecimento! 
Só se pode alcançar um grande êxito quando nos mantemos fiéis a nós mesmos.

Friedrich Nietzsche 


\section{RESUMO}

SOUZA, Gisele Pereira de. Linguagem de especialidade da Ciência da Informação: estudo exploratório a partir dos periódicos brasileiros da área entre 2005 e 2009. São Paulo, 2011. 104 p. Dissertação (Mestrado) Departamento de Biblioteconomia e Documentação, Escola de Comunicações e Artes, Universidade de São Paulo, São Paulo, 2011.

Resumo: Analisa a linguagem de especialidade da Ciência da Informação com base na análise das palavras-chave dos artigos dos periódicos Ciência da Informação, Informação \& Sociedade: estudos e Perspectivas em Ciência da Informação. Discute acerca da aplicação dos conceitos e da apresentação ou não de sua definição, e do possível consenso implícito na não apresentação do conceito nos artigos. Utiliza método exploratório para criar uma lista de conceitos que serão coletados e analisados em referência às teorias e práticas da Terminologia. As palavras-chaves selecionadas para a análise terminológica apresentavam frequência de até 5 ocorrências nos artigos analisados, e foram registradas em relação a sua citação no resumo do artigo, no texto do artigo, e quando ocorria no texto do artigo, se continha traços ou características que as configurassem como termo. Observou que 62\% das ocorrências de palavraschave não possuíam traços ou características que as configuram como termo. Constata que a linguagem de especialidade da área encontra-se difusa, sem definição clara do domínio ao qual os termos (nesse caso oriundos das palavraschaves) se referiam. Conclui, a luz do conceito de linguagem de especialidade, que a Ciência da Informação possui uma linguagem de especialidade, porém não confere grau ou intensidade dessa especialização.

Palavras-Chave: Ciência da Informação; Terminologia; Linguagem de Especialidade. 


\begin{abstract}
SOUZA, Gisele Pereira de. Specialized language of Information Science: an exploratory study of Brazilian journals of the area between 2005 to 2009. São Paulo, 2011. 104 p. Dissertation (Master in Information Science) - Departamento de Biblioteconomia e Documentação, Escola de Comunicações e Artes, Universidade de São Paulo, São Paulo, 2011.
\end{abstract}

\begin{abstract}
Analyzes the specialized languages of Information Science based on the analysis of keywords of articles in the journals Ciência da Informação, Informação \& Sociedade: estudos e Perspectivas em Ciência da Informação. Discusses about the application of the concepts and the presentation of its definition or not, and can not show consensus implicit in the concept in the articles. Exploratory method used to create a list of concepts that will be collected and analyzed in reference to the theories and practices of Terms. The keywords selected for analysis terminology often had up to 5 occurrences in the analyzed articles, and were recorded in relation to their citation in the abstract of the article, in the text, and when it occurred in the text, it contained traits or characteristics how to configure that term. He noted that $62 \%$ of the occurrences of keywords did not have traits or characteristics that shape as a term. Notes that the language of the specialty area is diffuse, with no clear definition of the domain to which the terms concerned. In conclusion, the concept of a language specialty, information science has a language of expertise, but does not confer the degree or intensity of such expertise.
\end{abstract}

Key-words: Information Science; Terminology; Specialized languages. 


\section{LISTA DE TABELAS}

TABELA 1: Lista de palavras-chave analisadas em relação a sua frequência .. 60

TABELA 2: Lista de palavras-chave que apresentam traços ou características que as configuram como termo.

74

\section{LISTA DE QUADROS}

QUADRO 1: Quantidade de artigos por edição e por ano da publicação Ciência da Informação 64

QUADRO 2: Quantidade de artigos por edição e por ano da publicação Perspectivas em Ciência da Informação. 64

QUADRO 3: Quantidade de artigos por ediçao e por ano da publicação Informação \& Sociedade: estudos

65

\section{LISTA DE GRÁFICOS}

GRÁFICO 1: Quantidade de artigos por título de periódico.

GRÁFICO 2: Quantidade de palavras-chaves, em relação a quantidade de artigos por título de periódico

GRÁFICO 3: Proporção entre palavras-chave que possuem traços ou características que as configuram como termo e as que não possuem.............. 76 


\section{SUMÁRIO}

APRESENTAÇÃO

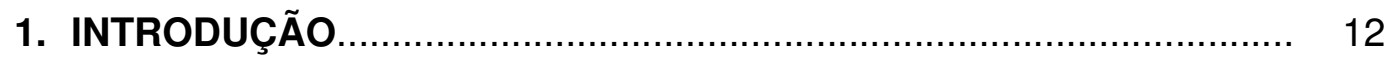

2. ASPECTOS DAS CIÊNCIAS SOCIAIS E DA CIÊNCIA DA INFORMAÇÃO EM RELAÇÃO A PÓS-MODERNIDADE ………............................. 21

2.1. A Ciência da Informação e suas características........................... 29

3. TERMINOLOGIA E LINGUAGEM DE ESPECIALIDADE: CONCEITOS E

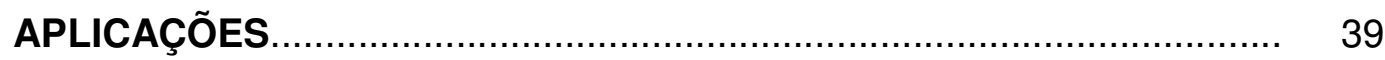

3.1. Aplicações da Terminologia junto à Ciência da Informação........... 47

4. PROCEDIMENTOS METODOLÓGICOS ............................................ 51

4.1. Seleção e Descrição da Amostra................................................ 53

4.2. Processo de Coleta e Registro das Palavras-Chave..................... 57

4.3. Processo das Aplicações das Palavras-Chave............................ 61

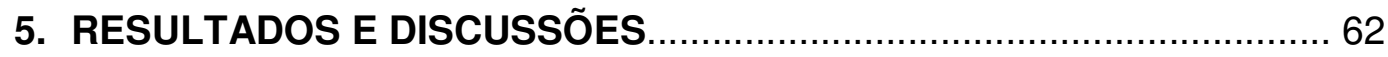

5.1. Palavras-Chave sem Descrição do Conceito............................. 69

5.2. Palavras-Chave com Descrição do Conceito............................ 74

6. CONCLUSÕES ................................................................... 78

7. REFERÊNCIAS BIBLIOGRÁFICAS............................................... 85

\footnotetext{
APÊNDICES

I - MODELO DE FICHA DE COLETA DE TERMINOLÓGICA....................... 93

II - PALAVRAS-CHAVE COLETADAS ................................................ 94
} 


\section{APRESENTAÇÃO}

A presente pesquisa é apresentada como dissertação de mestrado em Ciência da Informação, oferecido pelo Programa de Pós-Graduação em Ciência da Informação da Escola de Comunicações e Artes da Universidade de São Paulo. O tema a ser desenvolvido será um estudo exploratório sobre a linguagem de especialidade da Ciência da Informação.

$\mathrm{Na}$ Introdução, apresentamos a proposta deste trabalho em relação ao cenário atual de maturidade da Ciência da Informação, algumas iniciativas de pesquisa sobre sua linguagem de especialidade, considerações acerca do tema a ser desenvolvido e seu respectivo enfoque, as justificativas para a escolha da temática de investigação deste trabalho e os objetivos desta pesquisa.

No Capítulo 2 temos uma apresentação abrangente sobre a ciência que será nosso objeto de estudo, a Ciência da Informação, e suas características. Ainda nesse capítulo, abordaremos a questão das ciências sociais e sua inserção na contemporaneidade. $O$ capítulo 3 é dedicado à apresentação da Terminologia como ciência, das práticas terminológicas, dos conceitos de linguagem de especialidade e das relações que ambos estabelecem com a Ciência da Informação.

Em seguida, apresentamos como Capítulo 4, os Procedimentos Metodológicos para a realização da pesquisa, com destaque para a descrição pormenorizada do método exploratório desenvolvido.

Os resultados obtidos com a coleta das palavras-chave e a discussão de sua aplicação como conceito nos artigos pesquisados será discutida no Capítulo 5. As subdivisões deste capítulo foram organizadas de modo a apresentar de forma clara e objetiva o conteúdo encontrado em nossas pesquisas, que foi didaticamente agrupado em dois tópicos, para melhor visualização e entendimento dos resultados e das nossas proposições. 
Em Conclusões discutimos os aspectos observados ao longo da pesquisa e encerrando o trabalho e são arroladas as Referências utilizadas para a confecção desta dissertação. Integram também o trabalho os Apêndices, que são constituídos de modelo da ficha produzida para a coleta das informações extraídas do corpus de pesquisa, apresentado em detalhes no capítulo metodologia e uma listagem sintética de todas as palavras-chave encontradas durante a pesquisa, com destaque para as palavras-chave coletadas.

Pude perceber, ao longo do processo de pesquisa, o porquê de entregarmos um pré-projeto do que faremos em nível de pós-graduação, quando participamos da seleção. Entendo que pré seja referente a primeiro ensaio sobre o tema, e projeto por ser uma inspiração, um guia, para o que desejamos perseguir. A essência do que buscamos estudar sempre nos acompanhará até a defesa da dissertação, porém os caminhos para se chegar até o fim dessa jornada mudam. Assim como nunca entramos duas vezes num mesmo rio - muda o homem e muda o rio - a cada texto que lemos descobrimos novos caminhos, fazemos novas conexões, criamos diversas relações que tecem o pano de fundo da nossa pesquisa. 


\section{INTRODUÇÃO}

Esta pesquisa teve origem na monografia de conclusão do curso de graduação em Biblioteconomia e Documentação da Escola de Comunicações e Artes da Universidade de São Paulo - ECA/USP, realizada em 2006, que teve como título $O$ conceito contemporâneo de Ciência da Informação ante a terminologia consolidada da área. $\mathrm{O}$ trabalho apresentou uma comparação entre definições retiradas de obras de referência em Ciência da Informação e textos de autores contemporâneos (Aldo de Albuquerque BARRETO, Cristina Dotta ORTEGA, Lena Vânia Ribeiro PINHEIRO, Maria Cristiane Barbosa GALVÃO e Paulo César Rodrigues BORGES, Maria Nélida GONZÁLEZ DE GÓMEZ, Nair Yumiko KOBASHI e Maria de Fátima Gonçalves Moreira TÁLAMO). Possuía o objetivo de verificar a consolidação da Ciência da Informação como área do conhecimento através da terminologia em obras de referência confrontada com os conceitos difundidos em textos contemporâneos sobre o tema na literatura brasileira.

Neste trabalho, observei que as práticas terminológicas se mostraram de vital importância para o entendimento do conceito de informação e dos contornos da área de Ciência da Informação, doravante identificada pela sigla Cl. Constatei que essa prática se constitui num recurso para a representação do conhecimento técnico-científico especializado de forma organizada, necessário para a comunicação e o compartilhamento entre os pesquisadores por meio de uma mesma linguagem. Todo o processo terminográfico desde a coleta e descrição dos conceitos em seus contextos de uso até a identificação das características e sua sistematização, permitiu-me observar claramente a estrutura dos termos e as partes que os compõem, facilitando o entendimento do conceito e a identificação do mesmo nos textos trabalhados (SOUZA, 2006, p. 43-44).

Como uma das principais conclusões, notei que a contribuição da terminologia para a consolidação da Ciência da Informação, como disciplina autônoma, pode ser significativa, ao passo que a construção de vocabulário especializado da área deveria ser uma das consequências dos resultados da pesquisa científica. Encontra-se neste trabalho uma das maiores motivações para 
a realização do aprofundamento de meus estudos em nível de pós-graduação, iniciando-se pelo mestrado.

Na literatura, observa-se que, inicialmente, as áreas de atividade hoje reunidas sob o título de Ciência da Informação tinham como foco a resolução de questões práticas e pouca preocupação com a reflexão. Raros os autores que procuravam verificar os fundamentos da atividade e sua instituição como área distinta. Em âmbito mundial, alguns estudiosos, em sua maioria pesquisadores de instituições norte-americanas e europeias, tais como Rafael Capurro, Tefko Saracevic, Michael Buckland, Miguel Ángel Rendon Rojas (pesquisador da Universidad Nacional Autónoma do México) e outros, mostram sua preocupação por meio de variada produção científica sobre o assunto.

Na América Latina os estudos epistemológicos da área mostramse mais significativos após os anos 1990. O Brasil segue a mesma tendência e é nesta época que se apresentam com maior intensidade os estudos epistemológicos como tentativa de resgatar as origens e fundamentações teóricas da área. Porém, ainda temos pouca produção nacional em comparação a outras linhas de pesquisa.

Tomemos como referência o trabalho de Silveira e Bazi (2008) ao constatarem que apenas 9\% dos 386 artigos, veiculados entre 1995 a 2005 em um periódico relevante da área, o título Ciência da Informação, editado pelo IBICT, se referiam à temática do GT 1 da Associação Nacional de Pesquisa e Pós-graduação em Ciência da Informação (ANCIB): Estudos Históricos e Epistemológicos da Informação ante $20 \%$ referentes ao GT 2: Organização e Representação do Conhecimento. A categorização do trabalho de Silveira e Bazi foi realizada utilizando as sete áreas dos Grupos de Trabalho do ENANCIB de 2005, ou seja, do encontro anual de pesquisadores em Ciência da informação, promovido pela ANCIB. O cenário atual se traduz, ainda, na carência de estudos sobre a terminologia da área.

Por se tratar de uma área relativamente nova, a justificativa mais utilizada para a não definição dos conceitos é de que esta está em consolidação como campo científico além de sua característica interdisciplinar, reconhecida consensualmente pelos autores que refletem acerca do estatuto científico da $\mathrm{Cl}$. 
No entanto, verifica-se recentemente um esforço de diversos pesquisadores brasileiros cujos trabalhos tendem a sugerir a Ciência da Informação como uma área do conhecimento, cujas origens estão intimamente ligadas à Biblioteconomia e à Documentação, como também à Arquivologia e Museologia. Os trabalhos de Murguia (2010), Souza (2008), Bentes Pinto, Cavalcante e Silva Neto (2007), Smit e Tálamo (2007), Toutain (2007), Aquino (2002) , apenas em âmbito nacional, são diferentes visões sobre as questões epistemológicas, sociais, estruturais e interdisciplinares que povoam as pesquisas contemporâneas em Ciência da Informação.

O levantamento dos conceitos fundamentais para constituição da Ciência da Informação como área do conhecimento pode ser um meio de esclarecer as relações de inter, pluri e/ou transdisciplinaridade que estão em discussão. Fato esse abordado por Kobashi, Smit e Tálamo (2001) ao afirmarem que "o trabalho terminológico na área surge como uma das possibilidades de reintrodução do significado perdido/oculto, de natureza identitária, do significante 'Ciência da Informação'. Recorre-se assim ao processo de descoberta da área e não ao de demonstração do que ela é, como usualmente se faz" 1 .

Estudar as características dos conceitos, sua origem, campo(s) do conhecimento ao qual estão relacionados e definição terminológica, apresenta-se como forma de contribuir para a fundamentação da área, na medida em que se compreende melhor sua linguagem de especialidade. Entendemos também como contribuição o apontamento para a questão do reforço da identidade científica da $\mathrm{Cl}$, que necessite de uma maior estruturação e delineamento de seu discurso e de seu núcleo de conceitos básicos.

Pode-se afirmar que a Ciência da Informação é uma área do conhecimento em consolidação, não tendo muito definida sua terminologia, seja pela carência de estudos ou pela mera importação, sem reflexão, de termos e conceitos de outras áreas. Essa ausência de conceitos acarreta dificuldades para a área, não permitindo entendimento ou levando ao entendimento parcial e incompleto do seu funcionamento efetivo. De fato, uma área só pode afirmar-se como tal se dispõe de um conjunto de conceitos que se articulam internamente

\footnotetext{
${ }^{1}$ Por ser veiculado em revista exclusivamente digital o artigo não possui paginação.
} 
permitindo falar de sua especificidade. Fato este também identificado por Barbosa (1990), ao afirmar que "Qualquer disciplina e, com maior razão, qualquer ciência tem necessidade de um conjunto de termos rigorosamente definidos, pelos quais designa as noções que lhe são úteis: esse conjunto de termos constitui, pois, a sua terminologia".

Considerada uma ciência pós-moderna (BORKO, 1968; WERSIG, 1993; PINHEIRO e LOUREIRO, 1995; SARACEVIC, 1996; LE COADIC, 2004 entre outros) a Ciência da Informação ainda carece de trabalhos sobre as raízes de sua interdisciplinaridade, que muitas é vezes apresentada, mas pouco fundamentada. O mesmo cenário se configura quando tratamos de estudos sobre a terminologia utilizada pela Ciência da Informação, que configuraria como sua linguagem de especialidade, merecendo destaque para os grupos das instituições ECA/USP, FFCL-RP/USP, UFRJ/IBICT, UFRGS, UNB e UFMG.

A necessidade de organização dos conceitos e termos de uma área como a Ciência da Informação, que procura no passado sua identidade para reafirmá-la no presente e vislumbrar seu futuro, é colocada por alguns autores como uma parte importante do alicerce que sustentará seu crescimento. A bibliografia sobre a terminologia da Ciência da Informação, em língua portuguesa, é pouca, porém contando com expressivos trabalhos como os de Van Der Laan e Alvorcem (2007), Smit, Tálamo e Kobashi (2004), Válio e Oliveira (2003) e Medeiros (1986).

O primeiro trabalho localizado sobre a questão da Terminologia da Ciência da Informação foi publicado no ano de 1986 por Marisa Medeiros ${ }^{2}$ no periódico Ciência da Informação, e abordava uma analise da coleta de 473 termos que constavam nos títulos e resumos dos artigos do periódico Ciência da Informação entre os anos de 1972 e 1983, e também das teses incluídas no Catálogo de Dissertações e Teses publicados entre os anos de 1972 a 1984 (1986, p.137-138).

\footnotetext{
${ }^{2}$ A pesquisadora da Universidade de Brasília atualmente é reconhecida como Marisa Brascher, e não pelo último sobrenome Medeiros (Marisa Brascher Basilio Medeiros).
} 
Já Válio e Oliveira optaram por uma pesquisa embasada por teorias da análise do discurso, especificamente na perspectiva estruturalista de Foucault, tomando como corpus de análise textos dos autores $\mathrm{H}$. Wellisch e A. M. Schrader, e um único texto que abordava aspectos epistemológicos da Ciência da Informação da autora Maria Cristiane Galvão (2003, p.118).

Com um trabalho que abrangeu maior período temporal, compreendendo os anos de 1970 e 1998, as autoras Johanna Smit, Maria de Fátima Tálamo e Nair Kobashi coletaram 118 termos em fontes especializadas tais como dicionários, artigos de periódicos, livros, anais de congressos, além de vocabulários e tesauros da área (2004).

As autoras Regina Van Der Laan e Rochelle Alvorcem, da Universidade do Rio Grande do Sul, analisam a terminologia no discurso dos especialistas em Ciência da Informação coletando e analisando 38 termos diretamente do corpus textual de artigos publicados entre 2000 e 2005 no periódico Ciência da Informação (2007, p.111). O princípio norteador da pesquisa residia na "relação de comunicação entre o usuário e o sistema de recuperação da informação" (2007, p. 108). O uso da terminologia como auxiliar na produção de instrumentos de representação documental é uma temática recorrente entre as pesquisas e esta relação será discutida posteriormente.

Dentre todos os trabalhos anteriormente citados, a linguagem de especialidade esteve presente como decorrência do estudo da terminologia da área e não como foco principal do estudo. Entendemos que a linguagem de especialidade é um aspecto fundamental para a constituição de uma área, para o reconhecimento de uma disciplina como ciência autônoma, como instrumental eficiente para a efetiva comunicação entre os pares e também como denominador que fornece identidade a uma área.

A Cl está num momento de amadurecimento de suas práticas e teorias, que justifica a organização de sua terminologia, a delimitação de sua linguagem de especialidade para que esta possa servir como um importante referencial de sua existência, maturidade e importância social. 
Tal preocupação é compartilhada por Capurro e Hjørland (2007, p. 149) ao afirmarem que "para uma ciência como a Ciência da Informação, é sem dúvida importante a forma como seus termos fundamentais são definidos e, assim como em outros campos, na Ciência da Informação a questão sobre como definir informação é frequentemente levantada". Os autores fazem referência especificamente ao termo informação, por constituir um termo que compõe o nome do campo. Contudo, acreditamos que esta afirmação pode ser aplicada a todo o corpus terminológico da área em questão.

Todas as grandes áreas do conhecimento consolidam seus conceitos e terminologias em dicionários, glossários ou outros instrumentos similares. Como afirma Benveniste, "... a história particular de uma ciência se resume na de seus termos específicos. Uma ciência só começa a existir ou consegue se impor na medida em que faz existir e em que impõe seus conceitos, através de sua denominação" (BENVENISTE, 1989, p.142).

Convém, então, verificar em que grau isso ocorre na Ciência da Informação. "A terminologia trabalha com as palavras em funcionamento, o que permite delimitar seus valores e sua significação dentro do universo onde elas ocorrem" (LARA, 1993, p. 73). Numa fase mais avançada, essa terminologia se mostra consolidada e sedimentada em obras de referência.

O panorama apresentado por Medeiros no ano de 1986 ainda é válido se o transpusermos para os dias atuais. A autora afirma que

Apesar da indiscutível importância dos estudos terminológicos, constatase ainda, no Brasil, a carência desses estudos e de terminologias em Ciência da Informação. Em conseqüência, surgem problemas de ordem terminológica, tais como: ambigüidade, polissemia, uso indiscriminado de termos provenientes de línguas estrangeiras e criação de neologismos, sem levar em conta os padrões morfossintáticos da língua portuguesa. Esses problemas evidenciam a necessidade de padronização da terminologia brasileira em Ciência da Informação. (MEDEIROS,1986, p.135).

Exemplo da necessidade de sedimentação dos conceitos utilizados por uma área do conhecimento que se relaciona diretamente com a Ciência da Informação é o lançamento, em 2008, do Dicionário de Biblioteconomia e Arquivologia, por Murilo Bastos da Cunha e Cordélia Robalinho de Oliveira Cavalcanti. Mostrou-se uma grande contribuição aos estudos da área em língua portuguesa que, até então, dispunha somente de um glossário bilíngue 
(português-inglês) $^{3}$. Porém, em âmbito nacional observa-se a carência de obras de referência em Ciência da Informação, tendo como representantes dessa ordem alguns endereços eletrônicos de glossários e dicionários produzidos por grupos de estudantes e professores de universidades públicas, como UFES e UNB ${ }^{4}$.

Aplicada com sucesso na Documentação para, entre outros usos, auxiliar a produção de linguagens documentárias de várias áreas do conhecimento, as práticas da Terminologia ainda são pouco empregadas para a fundamentação da Ciência da Informação como área do conhecimento. A Terminologia trabalha amplamente com o estudo e delimitação das linguagens de especialidade; no caso da $\mathrm{Cl}$ não temos conhecimento de trabalhos que transcendam a esfera da identificação dos termos, ampliando seu potencial para sustentar epistemologicamente o campo, justificando sua abrangência, seu objeto de estudo e seus objetivos.

No âmbito da Ciência da Informação, a Terminologia é integrada à pesquisa como fonte de método e de técnicas que dão apoio à estruturação de linguagens documentárias, à construção de tesauros e ontologias. O estudo da Terminologia pela área tem seu início nos anos 1990, passando a integrar o conjunto das áreas com as quais a Ciência da Informação dialoga para estabelecer seu corpo básico de conhecimentos e procedimentos.

A utilização das metodologias de coleta, interpretação, tratamento e apresentação dos dados são entendidas como a aplicação prática da Terminologia, tendo diversas finalidades, sejam elas para um sistema linguístico, tradução ou planejamento de uma língua (BARROS, 2004, p.46). Da coleta e descrição dos conceitos em seus contextos de uso, até a identificação das características e sua sistematização, o processo terminográfico permite observar

\footnotetext{
${ }^{3}$ ARRUDA, Susana Margaret de; CHAGAS, Joseane. Glossário de Biblioteconomia e Ciências Afins. Florianópolis: Cidade Futura, 2002

${ }^{4}$ Dicionário Eletrônico de Terminologia em Ciência da Informação - DeltCl, coordenado por representantes das intuições do Departamento de Ciência da Informação da UFES (Brasil) e Secção Autónoma de Jornalismo e Ciências da Comunicação, FLUP da Faculdades de Letras da Universidade do Porto (Portugal) disponível em http://www.ccje.ufes.br/arquivologia/deltci/. O Glossário Geral de Ciência da Informação, elaborado por alunos e professores da Faculdade de Ciência da Informação ( $\mathrm{FCl}$ ) da Universidade de Brasília, disponível em http://www.cid.unb.br/publico/setores/100/123/sistema/m0039015.htm
} 
claramente a estrutura dos termos e as partes que os compõem, facilitando o entendimento do termo.

A abordagem via características - representações mentais de propriedades de um objeto (BARROS, 2004, p.107) - é considerada eficaz sendo que por meio delas é possível analisar diferentes contextos e épocas. Embora se debata contemporaneamente sobre a pertinência de considerar as características como representações mentais (LARA, 1999), é indiscutível que o trabalho sobre as características corrobora o diálogo entre Terminologia e Ciência da Informação, permitindo operacionalizar a identificação dos conceitos dessa área, para chegar a uma visão do seu estágio no momento contemporâneo.

Em alguns estudos, observamos o uso pelos pesquisadores da Ciência da Informação, da terminologia como instrumento para a construção de linguagens para representação da informação, obtendo resultados positivos. Constitui-se num recurso para a representação do conhecimento técnico-científico especializado de forma organizada, necessário para a comunicação e o compartilhamento entre os pesquisadores, por meio de uma mesma linguagem.

Dentro do campo da terminologia encontramos base para nossa abordagem em Krieger e Bevilacqua (2005, p. 2) quando estas afirmam que

Sob um ângulo mais genérico, podemos dizer que a Terminologia, ao ser revista criticamente, também avançou porque procurou novas respostas, em muito, oferecidas pela ciência da linguagem, aparelhando-se teórica e metodologicamente para enfrentar problemas, relacionados por exemplo, com a identificação dos termos de uma determinada área de conhecimento. Entre essas questões problemáticas, podemos lembrar de alicerces do pensamento terminológico - os termos e as ciências -, objetos, cuja apreensão não pôde mais ser linear em razão de grandes alterações que sofreram, como:

- a proliferação dos termos técnico-científicos em escala nunca antes vista, o que logicamente está associado à ampliação horizontal e vertical do conhecimento, das técnicas e das tecnologias. Tal proliferação veio também revelar a inexistência de fronteiras rígidas, no plano significante, entre léxico geral e especializado, tornando mais complexa a tarefa de reconhecimento de unidades terminológicas especializadas;

- a crise do conhecimento estruturado, que não mais se submete a um fechamento, mas se constitui em redes, abrindo-se a ciências conexas àquela que constitui o eixo central, determinando relações que se entremeiam sob a forma da inter e da multidisciplinaridade. Diante da fragmentação dos sistemas cognitivos hierárquicos que cedem espaço à coexistência de saberes, a Terminologia está sendo levada a reequacionar os esquemas de apreensão e tratamento das terminologias em dimensões mais amplas, cujos passos refletem, 
mesmo que, indiretamente, uma consonância com a epistemologia das ciências.

Uma área só se firma como ciência de fato quando organiza seu corpus teórico e prático, estrutura suas bases e consolida seu conhecimento em publicações que se tornam imprescindíveis à pesquisa e ao desenvolvimento da mesma (WHITLEY, 1974).

Sendo assim, este estudo preliminar propõe-se como contribuição para a consolidação da terminologia da Ciência da Informação, a partir da coleta de termos e identificação da sua conceptualização, ou inexistência dela, no corpus textual dos artigos pesquisados, referentes á produção científica em âmbito nacional. A importância de tal investigação científica justifica-se ainda com base na afirmação de Medeiros de que

Os esforços no sentido de estabelecer uma terminologia brasileira na área têm sido insuficientes como assim o demonstra a carência de glossários, dicionários e vocabulários e de estudos terminológicos na área de Ciência da Informação, tornando difícil a implantação e o fortalecimento de uma terminologia em língua portuguesa (MEDEIROS, 1986, p.141).

A pesquisa tem como objetivo geral analisar a linguagem de especialidade da Ciência da Informação com base na aplicação dos conceitos em artigos de periódicos científicos da área ${ }^{5}$.

Como objetivos específicos tem-se:

1) Discussão acerca da aplicação dos conceitos e da apresentação ou não de sua definição, e do possível consenso implícito na não apresentação do conceito nos artigos;

2) Proposição de uma metodologia para a constituição de uma lista de termos que possibilite a análise da linguagem de especialidade em Ciência da Informação.

\footnotetext{
${ }^{5}$ Detalhes da metodologia e amostra serão aboradados no capítulo 4-Procedimentos Metodológicos.
} 


\section{ASPECTOS DAS CIÊNCIAS SOCIAIS E DA CIÊNCIA DA INFORMAÇÃO EM RELAÇÃO A PÓS-MODERNIDADE}

A descrição do cenário social no qual uma ciência está inserido é de suma importância para o entendimento de suas especificidades. Tal importância é descrita por Pestre (1996) ao afirmar que

Aquele que pratica ciências é alguém que adquiriu uma certa cultura, que foi formado, modelado por um certo meio, que foi fabricado no contato com um grupo e com ele compartilhou as atividades - e não uma consciência crítica, operante, um puro sujeito conhecedor. Aculturado num conjunto de práticas, de técnicas, de habilidades manuais, de conhecimentos materiais e sociais, ele é parte intrínseca de uma comunidade, de um grupo, de uma escola, de uma tradição, de um país, de uma época.

Uma dessas especificidades é a linguagem própria dos participantes de uma rede de relacionamentos exercida durante a produção, aplicação e ensino de um campo do conhecimento. A linguagem compartilhada pelos sujeitos desse campo do conhecimento é utilizada para promover entendimento compartilhado dos conceitos expressos, possibilitando ampla comunicação entre os falantes, e também para diferenciá-los em relação ao pertencimento ou não àquele campo do conhecimento.

Tal linguagem, que no próximo capítulo será definida e explicitada como linguagem de especialidade, é produto dos discursos desses sujeitos, que a concretizam em atividades sociais e relacionais, e não produz significado fora desse contexto. No nosso caso, trabalharemos com a linguagem de especialidade da Ciência da Informação e, assim sendo, apresentaremos a questão da pósmodernidade e os fatores que a diferenciam dos outros períodos histórico-sociais.

Os limites temporais entre os períodos denominados modernidade e pós-modernidade são tênues, líquidos, em muitos casos divergentes e ainda se encontram em discussão por diversos teóricos. O filósofo francês Gilles Lipovetsky expressa esse cenário ao afirmar que "Pós-moderno: no mínimo, dirse-á que não se trata de uma noção clara, remetendo antes para níveis e esferas de análise que é por vezes difícil fazer coincidir" (LIPOVETSKY, 2006, p. 76). Porém, as características marcantes de cada uma dessas denominações estão minimamente consolidadas e é com elas que trabalharemos nesse momento. 
Por modernidade entende-se o período histórico-social delimitado entre, sem absoluto consenso, a tomada de Constantinopla em 1453 e o término da Revolução Francesa em 1789, sendo considerada uma época de revolução social fundamentada na substituição do modo de produção feudal pelo modo de produção capitalista. As grandes navegações e os intercâmbios culturais, econômicos e sociais proporcionaram um maior desenvolvimento comercial e urbano, à medida que ocorria menor conflito por territórios, maior controle das epidemias e desenvolvimento da ciência e medicina. $O$ próspero comércio possibilitou abundância de recursos financeiros que foram revertidos em apoio às artes. O Renascimento, a Revolução Científica e o lluminismo, que compreendem três séculos de mudança intelectual, são vistos por Burke como os "principais movimentos culturais do período" (BURKE, 2003, p.39).

O historiador Jaques Le Goff (2003), em sua obra História e memória, dedica um capítulo inteiro à dicotomia Antigo/Moderno, abordando conceitos de modernidade, modernização, modernismo e, ao final do texto, afirma que "mesmo que ultrapasse o domínio da cultura, [modernidade] refere-se, antes de mais nada, a um meio restrito, de intelectuais e tecnocratas" (2003, p. 202). Para o autor "fenômeno da tomada de um progresso, por vezes contemporânea da democratização da vida social e política, a modernidade mantém-se no plano da elaboração de uma elite, de grupos, de capelas" (LE GOFF, 2003, p. 202) e nessa visão, como o próprio autor afirma, reside "uma das ambiguidades da modernidade" (LE GOFF, 2003, p. 203).

O homem moderno não mais temia a Deus e voltou-se para o conhecimento de si próprio e para a dominação da natureza. O uso da razão e não somente da crença para conhecer o mundo fundamenta-se na pesquisa, na investigação e na experimentação da natureza e do próprio corpo humano, como fonte de conhecimento tanto para a cura de doenças como para a produção de máquinas tão perfeitas como ele. Burke propõe que o conjunto dos termos em destaque acima "sugere uma consciência crescente da necessidade de buscas para que o conhecimento fosse sistemático, profissional, útil e cooperativo" (BURKE, 2003, p.48-49). 
Complementar a essa visão, temos a colocação de Giddens ao conceituar preliminarmente que a "modernidade refere-se a estilo, costume de vida ou organização social que emergiram na Europa a partir do século XVII e que ulteriormente se tornaram mais ou menos mundiais em sua influência. Isto associa a modernidade a um período de tempo e a uma localização geográfica inicial [...]" (GIDDENS, 1991, p. 8).

\section{Berman conceitua modernidade segundo uma perspectiva}

dinâmica e dialética ao afirmar que "ser moderno é encontrar- se em um ambiente que promete aventura, poder, alegria, crescimento, autotransformação e transformação das coisas em redor - mas ao mesmo tempo ameaça destruir tudo o que temos, tudo o que sabemos, tudo o que somos" (BERMAN, 1998, p. 15). Para tentar controlar "algo tão vasto quanto a história da modernidade" (BERMAN, 1998, p. 16) o autor a divide didaticamente em três fases, a saber:

a primeira fase, do início do século XVI até o fim do século XVIII, as pessoas estão apenas começando a experimentar a vida moderna; mal fazem idéia do que as atingiu. Elas tateiam, desesperadamente mas em estado de semicegueira, no encalço de um vocabulário adequado; têm pouco ou nenhum senso de um público ou comunidade moderna, dentro da qual seus julgamentos e esperanças pudessem ser compartilhados. Nossa segunda fase começa com a grande onda revolucionária de 1790. Com a Revolução Francesa e suas reverberações, ganha vida, de maneira abrupta e dramática, um grande e moderno público. Esse público partilha o sentimento de viver em uma era revolucionária, uma era que desencadeia explosivas convulsões em todos os níveis de vida pessoal, social e política. Ao mesmo tempo, o público moderno do século XIX ainda se lembra do que é viver, material e espiritualmente, em um mundo que não chega a ser moderno por inteiro. É dessa profunda dicotomia, dessa sensação de viver em dois mundos simultaneamente, que emerge e se desdobra a idéia de modernismo e modernização. No século $X X$, nossa terceira e última fase, o processo de modernização se expande a ponto de abarcar virtualmente o mundo todo, e a cultura mundial do modernismo em desenvolvimento atinge espetaculares triunfos na arte e no pensamento. Por outro lado, à medida que se expande, 0 público moderno se multiplica em uma multidão de fragmentos, que falam linguagens incomensuravelmente confidenciais; a idéia de modernidade, concebida em inúmeros e fragmentários caminhos, perde muito de sua nitidez, ressonância e profundidade e perde sua capacidade de organizar e dar sentido à vida das pessoas. Em conseqüência disso, encontramo-nos hoje em meio a uma era moderna que perdeu contato com as raízes de sua própria modernidade (BERMAN, 1998, p. 16-17)

Autores como Giddens (1991), Berman (1998) e Le Goff (2003) conferem a Charles-Pierre Baudelaire a paternidade do termo "modernidade" ao cunhá-lo em seu artigo Le peintre de la vie moderne publicado em 1983. Na obra de Baudelaire o termo carrega aspectos da época em que vivia o autor e remete a 
noções de comportamentos e costumes próprios da segunda metade do século XIX.

As definições e características de modernidade apresentadas até o momento são amplas e sugerem certa ambiguidade de conceitos e abrangência. Ao mesmo tempo em que rompe com o passado e a Idade Média, retoma a Idade Antiga/Clássica como parâmetro para a arte, a literatura e a filosofia. Os antigos tinham sido modernos em seu tempo. Para Le Goff, essa ambiguidade é sintetizada com a colocação de que

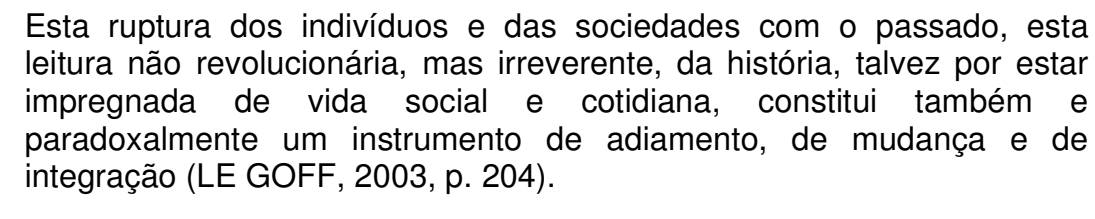

Verificamos que a modernidade está ligada a uma visão de mundo relacionada ao projeto de mundo moderno, comportando uma formação social até então nova em relação ao período pós-idade média, o surgimento da sociedade capitalista. Nessa sociedade, observou-se uma retomada dos princípios clássicos da racionalidade, a visão do homem como senhor de sua trajetória e motor da produção de conhecimento advindo da experimentação da natureza, necessidade de normatização dos processos para produção de ciência.

Apresentamos o contexto da modernidade com o intuito de embasar as discussões sobre a pós-modernidade e observamos na literatura consultada um questionamento: seria a pós-modernidade uma sequência da modernidade ou uma revolução dessa época? Nosso objetivo nessa dissertação não abrange a resolução dessa celeuma, mas sua citação se faz necessária para um melhor entendimento do cenário e da configuração da Ciência da Informação.

Uma definição bem delimitada para pós-modernismo é de Jair Santos no seu livro $O$ que é pós-moderno, como sendo "o nome aplicado às mudanças ocorridas nas ciências, nas artes e nas sociedades avançadas desde 1950, quando, por convenção se encerra o modernismo" (SANTOS,J., 1987, p.8). Para o autor o período surgiu com a arquitetura e a computação nos anos 50, seguido pela Pop arte dos anos 60, mantém relacionamento com a filosofia durante os anos 70 e na atualidade perpassa todos os campos do saber e o cotidiano humano. 
Outro autor que trabalha com as questões da pós-modernidade é o sociólogo Zygmunt Bauman, um dos principais popularizadores do termo. $\mathrm{O}$ autor utiliza dois períodos para descrever a modernidade, modernidade e pósmodernidade (BAUMAN 1998; 1999); porém, observa-se uma predileção pelos denominações modernidade sólida e modernidade líquida (BAUMAN 2001; 2004; 2006) em seus últimos trabalhos. Por modernidade sólida temos a ideia do projeto moderno, o controle do mundo pela razão, controle esse exercido pelo ordenamento racional e técnico.

Em contraposição, modernidade líquida é uma analogia à propriedade dos líquidos e gases de sofrem constantes mudanças de formas sob pressão. A sociedade pós-moderna, ou era da modernidade líquida para Bauman (2001) está em constante mudança, configurando uma realidade ambígua, muitas vezes multiforme. Essa sociedade é vista e criticada em relação aos critérios de individualidade, tempo/espaço, trabalho e comunidade, e possui como características marcantes a transformação do cidadão em sujeitos de direitos, onde o indivíduo está constantemente em busca de afirmação em seu lócus social; a mobilidade exagerada, 0 acesso às informações $e$ as redes de comunicação em tempo real cada vez mais rápido e desterritorializado produz um tempo acelerado na velocidade do movimento através do espaço, da imaginação e da capacidade humana; a liquidez das relações; transformação das estruturas de coletividade para a competição, necessidade de ser mais e melhor, o hedonismo, e egoísmo; enfraquecimento das lideranças que detinham o poder e a sabedoria e outros aspectos. Em suma, a modernidade sólida experimentou o controle racional do mundo, mas na modernidade líquida o mundo ruma para descontrole.

O crítico literário e teórico político norte-americano Fredric Jameson, em sua conferência no projeto Fronteiras do Pensamento, realizado em São Paulo em 25 de maio de 2011, defendeu que a principal característica da pós-modernidade seria a mudança da relação entre tempo e espaço, quase uma substituição de um pelo outro. Para ele o tempo é abolido e a realidade política e estética do espaço ultrapassou a ênfase modernista sobre o tempo. A conferência abordou a questão pós-moderna desde sua expressão nas artes, e nas relações 
humanas até a gastronomia molecular onde a forma do ingrediente utilizado é descaracterizada, enfatizando seus aromas e sabores.

A aplicação do conceito de pós-moderno estende aos substantivos as características intrínsecas do conceito e estão expressas no pensamento de Jameson na afirmativa que

De fato, uma das características mais marcantes do pós-moderno é o modo pelo qual, nesse período, inúmeras análises de tendências, até agora de natureza bastante diferente - previsões econômicas, estudos de marketing, críticas de cultura, novas terapias, jeremiadas (geralmente oficiais) contra as drogas e a permissividade, críticas de mostras de arte ou de festivais de cinema nacional, cultos ou revivals religiosos -, que se aglutinam todas para formar um novo gênero discursivo, a que podemos muito bem denominar de "teoria do pós-modernismo", e isso, por si só, já é um fato digno de nota. Trata-se, claramente, de uma classificação que inclui a si mesma [...]" (JAMESON, 1996, p.14).

Tema recorrente nas pesquisas científicas e produções acadêmicas em ciências humanas e sociais, a pós-modernidade não é apenas uma sucessão da modernidade. Está além da modernidade, sendo uma transformação de seus pilares, devido a fatores como a aceleração dos tempos e dos movimentos, choques de cultura, descrença nas instituições, alto grau de individualismo, múltiplas visões e questionamentos em relação a um mesmo ponto de vista, e subjetivismo. Em suma, perda de entusiasmo pelas convicções básicas do modernismo. Para o sociólogo Anthony Giddens, o tempo em que vivemos pode ser descrito como além da modernidade, onde "podemos perceber os contornos de uma ordem nova e diferente, que é pós-moderna; mas isto é bem diferente do que é atualmente chamado por muitos de "pós-modernidade" (GIDDENS, 1991, p. 9).

O próprio Giddens (1991), em seu livro As consequências da modernidade, afirma que o final do século XX é marcado por um momento em que as ciências sociais são questionadas a dar respostas sobre esse período de transição. Diversos termos são propostos para nomear essa nova era, desde um novo tipo de sistema social como em "sociedade de informação" ou a "sociedade de consumo", ou como a maioria apresenta, uma colocação sequencial de fatos culminando com o encerramento do período, como em "pós-modernidade", "pósmodernismo", "sociedade pós-industrial", e outros. O autor afirma que os debates sobre a temática estão centrados nas transformações institucionais, 
"particularmente as que sugerem que estamos nos deslocando de um sistema baseado na manufatura de bens materiais para outro relacionado mais centralmente com informação" (GIDDENS, 1991, p. 8-9).

Giddens retoma a obra de Jean-François Lyotard, para ele "o responsável pela popularização da noção de pós-modernidade" (GIDDENS, 1991, p. 9), ao evidenciar que o autor também possuía essa perspectiva, representada pela definição de que para Lyotard

pós-modernidade se refere a um deslocamento das tentativas de
fundamentar a epistemologia, e da fé no progresso planejado
humanamente. A condição da pós-modernidade é caracterizada por uma
evaporação da grande narrativa - o "enredo" dominante por meio do
qual somos inseridos na história como seres tendo um passado definitivo
e um futuro predizível. A perspectiva pós-moderna vê uma pluralidade de
reivindicações heterogêneas de conhecimento, na qual a ciência não tem
um lugar privilegiado (GIDDENS, 1991, p. 8-9).

A pós-modernidade também é discutida no nível antropológico como na proposta de Marc Augé, que pretere o termo pós-modernidade pelo termo, cunhado por ele mesmo, supermodernidade, que pode ser representada "por uma figura do excesso - o excesso de tempo - que se definirá, primeiro, a situação de supermodernidade, sugerindo que, pelo próprio fato de suas contradições, ela oferece um magnífico campo de observação e, no sentido lato do termo, um objeto para a pesquisa antropológica" (AUGÈ, 1994, p.33).

Inserida na sociedade pós-moderna, que passa por significativas transformações em suas estruturas e relações, a sociedade científica também questiona suas práticas e critica sua posição. O sociólogo Boaventura de Sousa Santos sintetiza o momento atual: "estamos no fim de um ciclo de hegemonia de uma certa ordem científica. As condições epistêmicas das nossas perguntas estão inscritas no avesso dos conceitos que utilizamos para thes dar resposta" (1987, p.9). Para o autor o paradigma dominante que perdurou durante os séculos XVI a XIX, baseado em modelos racionais de produção da ciência, sofre questionamentos na medida em que não contribui para o desenvolvimento da ciência ao não atender as necessidades da comunidade acadêmica-científica e da sociedade em geral. 
A sociedade pós-moderna necessita de mais reflexão e entendimento que o paradigma dominante pode subsidiar, e Santos nos apresenta o paradigma emergente como

Sendo uma revolução científica que ocorre numa sociedade ela própria revolucionada pela ciência, o paradigma a emergir dela não pode ser apenas um paradigma científico (o paradigma de um conhecimento prudente), tem de ser também um paradigma social (o paradigma de uma vida decente) (SANTOS, 1987, p.37).

A transição de uma sociedade moderna para a pós-moderna não é abrupta, se desenvolve num processo de assimilação das novas necessidades e adaptação do conhecimento existente a elas, sem a negação total do estabelecido e adoção do novo. Essas classificações são cunhadas por estudiosos do contexto social, comparando o momento atual com o anterior, e é possível que, daqui a alguns anos, esse período histórico-social tenha outra nomenclatura, porém as características intrínsecas ao processo de transformação serão as mesmas.

A mesma analogia pode ser empregada em relação a ciência, que é um produto social. Essa se transforma para adequar-se à nova realidade imposta pela sociedade em mudança e para acompanhar as tecnologias que possibilitam seu desenvolvimento. Produto da modernidade, a ciência moderna

nasceu da esmagadora ambição de conquistar a Natureza e subordiná-la às necessidades humanas. A louvada curiosidade científica que teria levado os cientistas 'aonde nenhum homem ousou ir ainda' nunca foi isenta da estimulante visão de controle e administração, de fazer as coisas melhores do que são (isto é, mais flexíveis, obedientes, desejosas de servir) (BAUMAN, 1999, p.48).

Para Santos (1989), neutralidade, racionalidade objetividade, pretensão universal, único e verdadeiro saber, entre outros pilares da Ciência Moderna, estão sendo questionados e encontram-se em sua mais aguda "crise de degenerescência"6. A modernidade pode ser caracterizada pela pretensão de instituir o conhecimento científico como o único saber, e Santos propõe que o senso comum também seja considerado como forma de conhecimento, ao afirmar que "o conhecimento do senso comum tende a ser um conhecimento mistificado e mistificador, mas [...] tem uma dimensão utópica e libertadora que pode ser

\footnotetext{
${ }^{6}$ Expressão cunhada pelo próprio Boaventura Sousa Santos que, em linhas gerais, expressam crises muito mais amplas, que apenas as crises de crescimento, como as propostas por Kuhn. A crise de degenerescência é uma crise de paradigmas que perspassariam toda a ciência e seriam mais profundas que as crises de crescimento.
} 
ampliada através do diálogo com o conhecimento científico (SANTOS, 1987, p.56).

As mudanças ocorridas na sociedade impulsionaram a pesquisa conjunta entre ciências, a interdisciplinaridade e alguns casos o surgimento de novas ciências. A Ciência da Informação é um exemplo desse processo.

\subsection{A Ciência da Informação e Suas Características}

Considerada uma ciência pós-moderna (BORKO, 1968; WERSIG, 1993; PINHEIRO e LOUREIRO, 1995; SARACEVIC, 1996; LE COADIC, 2004 entre outros), a Ciência da Informação ainda carece de estudos sobre as raízes de sua interdisciplinaridade que é muitas vezes apresentada, mas pouco fundamentada. O mesmo cenário se configura quando tratamos de pesquisas sobre a terminologia utilizada pela Ciência da Informação, merecendo destaque para os grupos de pesquisa sediados na ECA/USP, FFCL-RP/USP, UFRJ/IBICT, UNB e UFMG.

A Ciência da Informação, enquanto denominação, surge no pós $2^{\mathrm{a}}$ Guerra Mundial, durante a revolução científica e tecnológica proporcionada pela necessidade das potências de aumentarem seu poderio bélico e supremacia territorial, num período no qual as informações, então estratégicas, se tornaram disponíveis ao mundo. Nessa nova configuração mundial, surge a consciência da necessidade de dar acesso a toda essa informação acumulada, somada à informação que surgia e surgiria.

A tarefa de tornar acessível um acervo crescente de documentos foi apresentada à comunidade científica em um artigo de Vannevar Bush, em 1945, denominado As we may think. Nele, o autor identificou o problema do expressivo crescimento da informação e seus registros, principalmente em ciência e tecnologia, apresentando como solução o uso das tecnologias da informação, então em estágio embrionário. 
O universo da produção e disseminação do conhecimento aumentou e se diversificou de maneira tão profunda que as ciências, isoladas em si mesmas, não conseguiam atender a demandas de outras áreas da sociedade e, principalmente, do mercado, situação que levou alguns pesquisadores a procurarem soluções para problemas que as disciplinas como Biblioteconomia e Documentação, não conseguiam elucidar. É nesse momento, de extrema necessidade de seleção, organização, acesso e disseminação dessa magnitude de registros do conhecimento, que o embrião da Ciência da Informação encontra ambiente fecundo para fixar suas raízes.

A Ciência da Informação está inserida na complexa e atual sociedade pós-moderna. Sociedade essa, também denominada de pós-industrial, fortemente marcada pelo capitalismo informacional, que confere elevada importância ao acesso à informação e detenção do conhecimento.

O campo de uma ciência é delimitado por inúmeros princípios que norteiam suas pesquisas, suas ações em busca de algo que a diferencie e the forneça razão, ou importância, para existir na sociedade. O objeto de estudo é um deles. O objeto de estudo da Ciência da Informação é a informação registrada em um suporte físico ou virtual, que somente dessa forma poderá ser organizada e recuperada, provendo acesso eficiente e eficaz.

Ao retomarmos a questão da recuperação da informação enquanto relacionada à gênese da $\mathrm{Cl}$, remetemos à problemática apontada por Vannevar Bush (1945) em seu trabalho citado anteriormente. Em suma, podemos sintetizar que o objetivo da Ciência da Informação abrange a organização de informação registrada visando seu uso, promovendo o acesso às fontes de informação para que possam ser utilizadas e se tornar conhecimento novamente.

A Ciência da Informação trabalha com as representações físicas da informação que foram produzidas intencionalmente ${ }^{7}$ e podem ser selecionadas, organizadas e disponibilizadas aos usuários, para que possam produzir novos conteúdos, com base em seus estoques informacionais.

\footnotetext{
7 Importante ressaltar que os objetos museológicos também podem ser considerados representações físicas da informação, mesmo não sendo produzidos intencionalmente para essa finalidade, todavia sua musealização é intencional.
} 
Objeto de estudo da Ciência da Informação, o conceito Informação possui significados diferentes de acordo com o domínio do saber ao qual está relacionado, seja na Comunicação, Teoria da Informação e outros campos que se ocupam deste multifacetado objeto, porém no âmbito da Ciência da Informação o termo se refere à informação registrada em um suporte. Kobashi \& Tálamo apresentam o objeto de estudo da Ciência da Informação relacionandoo às incumbências da área: "[...] cabe à Ciência da Informação pensar e propor modos de organizar o caos informacional próprios das sociedades complexas. Configura-se um campo que explica os processos de comunicação nos quais intervém a informação registrada, tornada documento" (2003, p 16).

A dificuldade de definição do que seria Informação como conceito central para a Ciência da Informação se explica, entre outras justificativas, pela indeterminação natural do termo, que, ao mesmo tempo, remete ao processo de comunicação e a um produto, muitas vezes tratado como mercadoria.

Capurro e Hjørland expressam objetivamente essa preocupação no artigo $O$ conceito da informação, no qual apresentam diversos conceitos de informação definidos por outras ciências e disciplinas que compartilham conosco do mesmo termo como objeto de estudo, porém o conceito nem sempre é o mesmo para a $\mathrm{Cl}$.

Retomamos o caráter pós-moderno da Ciência da Informação para vincular junto ao seu objeto de estudo a questão do objetivo próprio dessa ciência. Essa vinculação está expressa na afirmação de González de Gómez (2003) que ressalva que

Em primeiro lugar, devemos esclarecer que o objeto de estudo da Ciência da Informação não poderia ser, a nosso ver, a informação de maneira não qualificada, como uma objetividade isolada e descontextualizada. A Ciência da Informação, assim, seria aquela que estuda fenômenos, construções, sistemas, redes e artefatos de informação, enquanto "informação" for definida por ações de informação, as quais remetem aos atores que as agenciam, aos contextos e situações em que acontecem e aos regimes de informação em que se inscrevem (2003, p. 32).

O pensamento de González de Gómez (2003) é amplo e abrange um espectro de atuação para a $\mathrm{Cl}$ em parcial sintonia com o enfoque dado por Le Coadic (2004, p. 26) em que o objeto da Ciência da Informação seria referente ao estudo das propriedades gerais da informação, de sua natureza, gênese e efeitos, 
ao passo que o estudo dos processos de criação, construção, comunicação e uso da informação, integrando também a concepção dos produtos e sistemas que permitem sua organização, comunicação, armazenamento e uso constituem-se em seu objetivo. Parcial no sentido de que González de Gómez remete a uma informação como processo, ação, e Le Coadic trabalha com a questão da cadeia produtiva da informação, que incluí também os processos, as ações de informações.

Informação é um conceito subjetivo, que não pode ser considerado isoladamente, é parte de processos interpretativos inerentes ao ser humano que se organiza em sociedade e participa de relações com outros sujeitos (BUCKLAND, 1991; CAPURRO e HJØRLAND 2007, LARA, 2008). A análise realizada por Buckland (1991) identificou três principais usos da palavra informação: como processo, relativa aos processos de informar, processar dados e informações; como conhecimento (intangível), para designar o que é percebido e interiorizado a partir da informação como processo; e como coisa, atributo de objetos como dados e documentos que contêm informatividade, a materialidade da informação como conhecimento.

A questão da informatividade dos documentos também é discutida por Lara, ao observar que as pesquisas e práticas em Ciência da Informação começam pela discussão do conceito de informação, mas que alguns autores se preocupam, além do conceito, com a informatividade dos documentos (LARA, 2008). A informatividade é situacional e está no sujeito que o interpreta, e não no objeto, ou seja, trata-se de uma característica atribuída aos documentos.

Para a Ciência da Informação, informação como coisa é importante ao remeter à questão do documento, que teve seu conceito ampliado por Otlet, tanto no sentido físico quanto virtual: um registro em uma base de dados é informação como coisa. A Ciência da Informação trabalha com as representações físicas da informação que podem ser selecionadas, organizadas e disponibilizadas aos usuários, para que possam produzir novos conteúdos, com base em seus estoques informacionais. 
$\mathrm{Na}$ atualidade, entendemos que além de organizar informação para recuperação, a Ciência da Informação também se ocupa com o processo de apropriação e uso dessa informação, ora apresentando-se como ciência moderna, ao alinhar a definição de seus objetivos em relação a um único objeto, ora como ciência pós-moderna, ao recorrer à interdisciplinaridade para a busca por soluções de problemas que ocorram no contexto da sociedade atual, oscilação expressa claramente por Smit e Tálamo ao afirmar que

\begin{abstract}
Ao mesmo tempo, ao caracterizar a "informação" como seu objeto, parecendo ignorar que ela não detém o monopólio sobre ele, estabelece um ciclo tautológico que por um lado evoca a ciência moderna, através da delimitação de uma disciplina pela definição de seu objeto, quando ao mesmo tempo argumenta a favor da informação para a ação, inserindo-a no fluxo do conhecimento, caracterizando a área como uma ciência pósmoderna, constituída para encaminhar soluções para problemas reais, concretos, que afligem a sociedade (SMIT \& TÁLAMO, 2007, p.43)
\end{abstract}

Influenciada por outras disciplinas, principalmente pela Documentação e a Recuperação da Informação, as origens da Ciência da Informação encontram-se expressas nos textos de diversos teóricos da área com destaque para Borko (1968), Rayward (1997), Wersig (1993), Saracevic (1995, 1996) e Capurro (2003). Pudemos observar que os pesquisadores norteamericanos, ou que possuem influência dessa corrente, indicam o surgimento dos fundamentos da Ciência da Informação no ano 1945, com o artigo de Vannevar Bush, e sua institucionalização por volta dos anos 1950. Em contraposição, os autores europeus, ou que possuem influência dessa corrente, creditam à documentação de Paul Otlet uma das origens da Ciência da Informação. Mesmo se desenvolvendo a partir de correntes diferentes, os princípios da Ciência da Informação são os mesmos. Princípio esse consolidado por Saracevic ao afirmar que "o despertar da Ciência da Informação foi o mesmo em todo o mundo" (1996, p.43).

Um dos autores pioneiros a teorizar sobre o campo, Borko em seu artigo Information Science: what is it de 1968, apresenta a Ciência da Informação como uma ciência interdisciplinar, que tem suas bases na Biblioteconomia e 
Documentação e se relaciona com áreas diversas, tais como linguística, lógica, tecnologia da informação ${ }^{8}$, psicologia, comunicação, administração e outros.

Identificamos que Rayward (1997), Saracevic (1996, 1995, 1999) e Capurro (2003) possuem pontos de contato e divergências em suas colocações sobre as origens do campo. Observamos que a pequena diversidade de origens atribuídas as $\mathrm{Cl}$ é extremamente importante para proceder à análise da configuração do campo. Os caminhos percorridos pelas pesquisas em Ciência da Informação, suas ênfases, influências, tendências e até mesmo temáticas pouco ou nada estudadas podem ser explicadas pelas bases herdadas.

Em oposição a Rayward (1997), que relaciona as origens da Ciência da Informação à Documentação e aos trabalhos de Paul Otlet e Henri La Fontaine junto à Federação Internacional de Documentação - FID, Saracevic (1996) identifica a origem da $\mathrm{Cl}$ no artigo As we may think produzido por Vannevar Bush em 1945, visto que "o ímpeto de desenvolvimento e a própria origem da Cl podem ser identificados com o artigo de Vannevar Bush" (1996, p. 42).

O problema proposto por Bush e que, para muitos autores, impulsionou o surgimento da Ciência da Informação, refere-se a encontrar uma forma de armazenar, organizar e recuperar o conhecimento produzido em ciência e tecnologia. No período histórico vivido por Bush não existiam tecnologias capazes de atender sua necessidade e a criação de uma máquina, em tese, resolveria o problema. Interessante observar que, já em 1945, ano de produção do artigo, havia a preocupação de se reunir em um único local o acesso a documentos sonoros, iconográficos, audiovisuais e textuais/bibliográficos, concretizando-se com a criação da web, aproximadamente 50 anos depois. No entanto, Bush projetou uma máquina, o Memex, prevendo um uso individual por parte de pesquisadores que reuniriam e organizariam, em suas máquinas "pessoais", as informações que Ihes parecessem úteis ou importantes.

\footnotetext{
${ }^{8}$ Adaptação ao termo correspondente atualmente, pois a época não existia a disciplina Tecnologia da Informação e sim algo como tecnologia dos computadores.
} 
Ainda sobre as origens da Ciência da Informação recorremos aos estudos do filósofo uruguaio Rafael Capurro que se ocupa, entre outros temas, da epistemologia da $\mathrm{Cl}$. O autor trabalha com duas grandes perspectivas em sua pesquisa, sendo uma caracterizada pelo estudo das questões sobre as raízes históricas do campo e outra pela tentativa de definição do conceito de "informação".

Em relação à primeira perspectiva, Capurro $(2003)^{9}$ nos apresenta uma visão das origens da Ciência da Informação relacionadas a "duas raízes: uma é a biblioteconomia clássica ou, em termos mais gerais, o estudo dos problemas relacionados com a transmissão de mensagens, sendo a outra a computação digital”. Essas duas raízes podem ser percebidas claramente na descrição dos três paradigmas propostos pelo autor em seu trabalho Epistemologia e Ciência da Informação, decorrente de sua apresentação no 5은 Encontro Nacional de Pesquisa em Ciência da Informação, realizado em Belo Horizonte, em 2003.

Os três paradigmas epistemológicos propostos pelo autor trazem uma visão auxiliar ao entendimento de diversas questões relativas à Ciência da Informação. Mas, como o próprio criador dessa proposta aponta

naturalmente que essa seleção e esquematização não só simplificam de
forma extrema a complexidade das proposições, como podem dar lugar
a um mal entendido, considerando a presente exposição como avanço
histórico, posto que muitas teorias se entrecruzam com distintas
intensidades e em diversos períodos (CAPURRO, 2003) ${ }^{10}$

Para Capurro (2003), a Ciência da Informação nasce com o paradigma físico em meados dos anos 1950, sendo substituído pelo paradigma cognitivo e social, observando-se que não são consequentes históricos, auto excludentes e em alguns momentos os paradigmas coexistem entre si. No paradigma físico, temos a Teoria matemática da comunicação ou Teoria da informação, proposta por Claude Shannon e Warren Weaver, que deve ser entendida pelos pesquisadores da Ciência da Informação como uma abordagem da recuperação da informação (information retrieval). Também no paradigma físico encontram-se a proposição de Buckland para a informação como fenômeno

\footnotetext{
${ }^{9}$ Por ser veiculado exclusivamente em meio digital o documento não possui paginação.

${ }^{10}$ Por ser veiculado exclusivamente em meio digital o documento não possui paginação.
} 
objetivo, algo tangível, objeto com valor informativo (BUCKLAND, 1991; CAPURRO, 2003).

No paradigma cognitivo, encontramos aspectos das teorias de Paul Otlet e a diferenciação de conhecimento e seu registro em documento; de Brookes com os conteúdos intelectuais, que retomado de Popper podem ser os documentos, formando uma rede em espaços mentais; culminando em Ingwersen que propõe a transformação de usuário (como tratados usualmente em Ciência da Informação, ignorando os contextos sociais, os estoques informacionais e as características plurais de cada ser humano) em sujeito cognoscente possuidor de necessidade de informação (CAPURRO, 2003; INGWERSEN, 1992).

A importância do paradigma social para a Ciência da Informação reside em se ater ao fato de que a informação não pode ser tratada como algo separado do mundo do sujeito e sua historicidade. $O$ sujeito possui condicionamentos do ser humano que devem ser observados e atendidos, dentro do possível, no desenvolvimento de sistemas de recuperação da informação, possibilitando assim uma interação homem-máquina mais eficiente e eficaz (CAPURRO 2003). Presente na obra de Capurro, mas também em outros autores, temos o conceito de relevância, observado tanto no paradigma físico, em termos de recuperação da informação, como no social, ao lidarmos com o relacionamento entre usuário e sistema de informação.

Por ser uma ciência pós-moderna a Ciência da Informação é inerentemente interdisciplinar. A grande maioria dos autores estudados indica esse fato e questioná-lo talvez não se faça necessário. A questão que nos parece merecer atenção é com quais disciplinas a Ciência da Informação se relaciona, de que forma, até que ponto essa relação pode ser caracterizada como sendo efetivamente de interdisciplinaridade ou mera importação de conceitos, ou como abordaremos posteriormente nos resultados, apenas uso do termo sem expressão de suas características ou traços que os configure como conceito.

Diante da colocação de Santos que

a ciência pós-moderna sabe que nenhuma forma de conhecimento é, em si mesma, racional; só a configuração de todas elas é racional. Tenta, pois, dialogar com outras formas de conhecimento deixando-se penetrar por elas $(1987$, p. 55) 
observamos que a Ciência da Informação como ciência pós-moderna transcende a monodisciplina e se vale de teorias e técnicas de outras ciências para poder atingir os objetivos complexos dessa nova sociedade na qual a $\mathrm{Cl}$ se encontra. Fato compartilhado por Saracevic ao retomar Popper de que "não somos estudantes de assuntos, mas estudantes de problemas" (SARACEVIC, 1999, p.1051).

Ainda sobre a pós-modernidade da Ciência da Informação, vale ressaltar a abordagem de Wersig para uma maior aplicabilidade, que a nosso ver pode ser perigosa se entendida pelo ângulo de uma Ciência da Informação estritamente técnica e não reflexiva. Concordo que a função das ditas ciências pós-modernas difere das ciências modernas, encarando pela ótica das transformações ocorridas nas sociedades que as influenciam, mas é importante lembrar que para se "desenvolverem estratégias para resolver problemas que foram causados pelas ciências e tecnologias clássicas" (WERSIG, 1993, p. 235) faz-se necessário não somente o domínio de conhecimento técnico, mas primordialmente as formas críticas e reflexivas do pensamento.

Outra característica da Ciência da Informação encontrada com frequência nos textos dos autores Ingwersen (1992), Saracevic (1995, 1996 e 1999), Buckland (2003), Capurro e Hjørland (2007) e Capurro (2003) está relacionado ao aspecto social do campo. A mais marcante das colocações foi encontrada no texto de Saracevic, especificamente em sua afirmação de que "A $\mathrm{Cl}$ teve e tem um importante papel a desempenhar por sua forte dimensão social e humana, que ultrapassa a tecnologia" (1996, p. 42).

As reflexões acerca da obra dos autores Ingwersen (1992), Saracevic (1995, 1996 e 1999), Buckland (2003), Capurro e Hjørland (2007) e Capurro (2003) permitiram reafirmar o caráter de ciência social da Ciência da Informação, voltando-se para questões relativas ao usuário/sujeito, sua interação com os sistemas de informação, a pertinência e relevância das informações fornecidas e outras abordagens com caráter mais humanista, sem esquecer-se da tecnologia como facilitadora. 
Wersig é inovador ao trazer para o campo da Ciência da informação a necessidade de pensarmos em modelos básicos por redefinição dos conceitos científicos genéricos, reformulação científica dos interconceitos e interuso de modelos e interconceitos ${ }^{11}$ para um melhor entendimento de sua identidade. O autor propõe uma reflexão sob o campo da Ciência da Informação em relação à percepção de que alguns conceitos que podem ser essenciais para registro e a transmissão do conhecimento da área não são estabelecidos em uma estrutura científica própria, e que muitos conceitos não estão sendo tratados cientificamente porque eles parecem pertencer ao senso comum. Estes são conceitos que têm sido eventualmente abordados pelas disciplinas tradicionais, num ponto de vista muito restrito fora da respectiva disciplina, são usados como conceitos do senso comum, não questionando que se por serem familiares aos consumidores desse conceito, acreditamos que todos irão entendê-los (WERSIG, 1993, p. 237) ${ }^{12}$.

A questão da fundamentação teórica do campo deve ser perseguida pelos pesquisadores em Ciência da informação para que possamos avançar em nosso status científico e consequente reconhecimento interno e externo. Para nós, a fundamentação teórica deve se concentrar também na elaboração de um corpus conceitual próprio, delimitando os termos utilizados nos discursos das pesquisas e dos profissionais da área. Tais trabalhos trarão mais consistência para Ciência da Informação, possibilitando a identificação de sua linguagem de especialidade e favorecendo os estudos dessa linguagem.

\footnotetext{
${ }^{11}$ Para Wersig os interconceitos são conceitos que se relacionam com um conjunto de disciplinas tradicionais sem ser compreendido transdisciplinarmente (1993, p.237).

${ }^{12}$ Livre tradução de "We will find that a lot of concepts we have to deal with are not being dealt with scientifically because they seem to belong to our common thinking. These are concepts which sometimes have been tackled by traditional disciplines, in each case a very restricted viewpoint, but outside the respective discipline they are used as common concepts, not being questioned because they seem to be so familiar that we think everybody will understand them." (WERSIG, 1993, p. 237) ${ }^{12}$.
} 


\section{TERMINOLOGIA E LINGUAGEM DE ESPECIALIDADE}

O capítulo que se segue apresenta as teorias da Terminologia e definições e conceitos sobre Linguagem de especialidade que nortearam todo o trabalho de pesquisa e concepção dessa dissertação. Por se tratarem do campo da Linguística e não da Ciência da Informação propriamente dita, encontramos determinadas barreiras na apreensão dos conceitos e dos contextos nos quais estes se aplicam. Esse capítulo configurou-se em um dos mais complexos a ser construído, porém imprescindível ao desenvolvimento e condução da pesquisa.

Trataremos, primeiramente, as definições de Terminologia. Definida pela norma ISO 1087-1:2000 como um "conjunto das designações (representação de um conceito por um signo que o denote) existentes em uma linguagem específica (linguagem usada em um domínio e caracterizada pelo uso de formas linguísticas específicas de expressão)" e também como uma "ciência que estuda a estrutura, a formação, o desenvolvimento, o uso e o gerenciamento das terminologias (conjunto das designações existentes em uma linguagem específica) em vários domínios" (ISO 1087, 2000, p.10), observa-se que a Terminologia pode ser abordada tanto como uma lista de termos, quanto o processo de construção da anterior.

A Terminologia se fundamenta como disciplina científica na década de 1930, na Alemanha, com a Escola Terminológica de Viena. Anteriormente, nos séculos séc. XVIII e XIX, a terminologia estava ligada intimamente às ciências naturais, confundindo-se com a nomenclatura na estruturação de regras para a criação de nomes científicos na botânica e na zoologia (BARROS, 2004, p. 31).

Devido à polissemia do termo terminologia, convencionou-se que quando expresso por T maiúsculo o termo se refere à disciplina, campo ou área do conhecimento que tem como objeto de estudo o termo, palavra técnica ou científica ou técnico-científica, e com t minúsculo aos produtos da primeira, tais como dicionários e glossários especializados, que contam como importante referencial interpretativo para os descritores e para as relações entre conceitos 
nas linguagens documentárias. Para fins didáticos, Lara (2005, p.3) propõe a distinção entre Terminologia teórica como o

conjunto das diretrizes e princípios que regem a compilação, formação de termos e estruturação de campos conceituais e terminologia concreta compreendida pelos conjuntos de termos que representam sistemas de conceitos relacionados a uma língua de especialidade ou área de atividade particular.

Entendida como campo do conhecimento que estuda as teorias e métodos relacionados aos discursos das linguagens de especialidade, para Lara e Tálamo (2007) $)^{13}$,

a Terminologia desenvolve reflexões teóricas sobre suas bases conceituais, como metodologias de trabalho. Seus objetivos aplicados se relacionam à observação dos discursos especializados nas áreas do saber ou de atividade, visando principalmente a construção de dicionários e glossários especializados. Funcionalmente, a Terminologia é veículo de conhecimento, aspecto importante para a descrição e recuperação da informação.

As primeiras teorias são constituídas nos anos de 1930, quando o engenheiro austríaco Eugen Wüster estabelece as bases da Escola Terminológica de Viena e elabora a Teoria Geral da Terminologia - TGT, acompanhado paralelamente por D. S. Lotte na antiga URSS, fundador da corrente soviética da Terminologia, com foco na sistematização das terminologias.

Com o desenvolvimento da informática e das tecnologias de informação e comunicação nos anos de 1960, o estudo e as práticas da Terminologia são favorecidos e, aliado à criação de cursos universitários em âmbito mundial e dos eventos científicos para discussão da área nos anos 1970, fortalecem a estruturação da área como disciplina.

Entre 1975 e 1985 observou-se um aumento do uso da Terminologia em processos de normalização e harmonização terminológicas e os avanços da informática auxiliaram o trabalho dos pesquisadores, tanto no levantamento, quanto no tratamento dos dados coletados. A partir de $1985 \mathrm{e} \mathrm{em}$ toda a década de 1990, a Terminologia ganha amplitude global possibilitando um aumento na produção de obras terminográficas em diversas áreas, a criação de redes internacionais, facilitando a cooperação e intercâmbio científicos, entre outras ações.

\footnotetext{
${ }^{13}$ Por ser veiculado em revista exclusivamente digital o artigo não possui paginação.
} 
Nota-se que em 1987 e em 1990 são publicadas pela ISO International Organization for Standardization, respectivamente, as normas ISO 704 - Terminology work - principles and methods e ISO 1087 - Terminology work - vocabulary. Part. 1 and 2, produzidas originalmente em inglês e francês. Outras normas terminológicas foram propostas pela ISO e algumas delas traduzidas pelo órgão nacional reconhecido como a ABNT - Associação Brasileira de Normas Técnicas, no caso do Brasil. Publicada pelo órgão em 1997, a norma NBR13790 Terminologia - princípios e métodos - harmonização de conceitos e termos, "tem por objetivo fixar o enfoque metodológico adotado na harmonização dos conceitos, dos sistemas de conceitos, das definições, dos termos e dos sistemas de termos" ${ }^{\prime 14}$.

Da década de 1990 até os dias atuais podemos verificar um momento de reflexão geral sobre os pressupostos teóricos e metodológicos da Terminologia. Pesquisadores questionam a Teoria Geral da Terminologia do ponto de vista de seu modelo normalizador e suas limitações, e então surgem novas propostas baseadas em uma visão comunicativa da linguagem, como a Teoria Comunicativa da Terminologia, apresentada por Maria Teresa Cabré. Outras abordagens sociais, cognitivas e relacionais tais como a Socioterminologia de Gaudin, Teoria Sociocognitiva da Terminologia de Temmermman e a Terminologia Cultural de Diki-Kidiri se apresentam como alternativas à pouca ou nenhuma preocupação com o caráter comunicacional da linguagem observada na TGT.

Retomando o conceito de terminologia para que possamos descrever os conceitos que nortearão nosso trabalho terminológico, recorremos a Maria Aparecida Barbosa, Profa. Dra. da FFLCH da USP e pesquisadora renomada dentro da área. Barbosa $(1990)^{15}$ afirma que "uma terminologia é um conjunto de palavras técnicas ou científicas, que constituem o vocabulário específico de uma ciência, de uma tecnologia, de um pesquisador ou grupo de pesquisadores, ou de uma área de conhecimento".

\footnotetext{
${ }^{14}$ Informação extraída do catálogo ABNT, disponível em http://www.abntcatalogo.com.br/norma.aspx?ID=4755, Acesso em: 10 jun. 2011.

${ }^{15}$ Por ser veiculado em revista exclusivamente digital o artigo não possui paginação.
} 
Em linha com as definições de Cabré (1995), Barbosa (1990), Barros (2004) e da norma ISO 1087-1:2000 a Terminologia é a ciência que tem como foco de seus estudos as linguagens de especialidade. As línguas ou linguagens de especialidades são próprias do campo de pesquisa da Terminologia. Utilizaremos o termo linguagem de especialidade neste trabalho tomando como base a teoria linguística de que a linguagem seria o uso da língua. Entretanto o termo língua de especialidade é amplamente conhecido e utilizado pela comunidade acadêmica em Terminologia e Linguística.

Segundo Dias (2000, p. 90), Sager e Cabré afirmam que

como teoria a terminologia é um conjunto de premissas, argumentos e conclusões, necessário para explicar o relacionamento entre conceitos e termos especializados; como prática é um conjunto de métodos e atividades voltado para coleta, descrição, processamento e apresentação de termos; como produto, é um conjunto de termos, ou vocabulário, de uma determinada especialidade.

Considerando as abordagens acima, supõe-se ser consenso entre os autores pesquisados que o conceito de Terminologia não é fechado. Cabré (1995), afirma que a polissemia do termo nos remete a pelo menos três aspectos: a disciplina, como a matéria que estuda os termos especializados; a prática, como conjunto de princípios utilizados para a coleta dos termos; e os produtos gerados pela prática, como sendo os termos de uma determinada especialidade.

Para melhor entendimento dos aspectos citados acima, Cabré (1995), apresenta a terminologia como objeto, definido por um conjunto de termos de uma especialidade, ressaltando três concepções para a palavra:

- para a linguística - os termos são conjuntos de signos linguísticos que constituem um subconjunto dentro do componente léxico de uma gramática geral ou especializada (forma de saber);

- para a filosofia - conjunto de unidades cognitivas que representam o conhecimento especializado (forma de conhecer);

- para as diversas disciplinas técnico-científicas - conjunto das unidades de expressão e comunicação que permitem transferir pensamento especializado (forma de comunicar). 
A concepção da terminologia para a linguística pode ser considerada com foco na gramática especializada, rica em componentes léxicos, restrita a um grupo com características comuns. Os grupos são formados pelos mais diversos públicos, sempre tendo como fator agregador interesses e necessidades comuns. Podem ser de profissionais, de amigos, de estudantes, de apreciadores de gêneros alimentícios ou de bebidas, de esportistas, entre outros, sendo que os participantes de cada grupo mantêm dialogo compreensível, muitas vezes se utilizando de termos entendidos somente pelos seus pares.

Os grupos que nos interessam são os que mantêm relações profissionais ou acadêmicas, pois suas práticas são, em sua maioria, oriundas de um conhecimento específico, seja ele pertencente ao campo social, cientifico ou tecnológico. Seleção esta explicitada em grande parte pela afirmação de Cabré $(1993, \text { p. } 37)^{16}$, citada por Krieger (2000, p. 211), de que "para los especialistas, la terminología es el reflejo formal de la organización conceptual de una especialidad, y un medio inevitable de exprésion y de comunicación professional".

Por linguagem de especialidade podemos citar a definição para o termo descrita pela ISO, como uma "linguagem utilizada em um domínio e caracterizada pelo uso de formas linguísticas específicas de expressão" (ISO $1087-1,2000$, p. 2). A linguagem de especialidade é o subsistema que compreende a terminologia e demais meios linguísticos de um campo científico, uma área, um domínio ou um subdomínio que objetiva uma comunicação eficaz e sem ambiguidades entre os sujeitos que a compartilham.

As linguagens de especialidade são compostas por unidades lexicais denominadas termos. Para Barros termo "é uma unidade lexical com o conteúdo específico dentro de um domínio especializado" (2004, p. 40). Essa unidade lexical é definida pela ISO como "uma designação, uma representação explicita de um conceito, dentro de uma linguagem de especialidade" (ISO 10871, 2000, p. 6). Os termos podem designar conceitos, objetos ou processos. Em se tratando de estudos no âmbito da Terminologia, os termos estão sempre

\footnotetext{
${ }^{16}$ CABRÉ, M. T. La terminología: teoría, metodología, aplicaciones. Barcelona: Antártida,
} 1993. 
associados a um sistema de conceitos relativos ao campo científico ao qual ele está relacionado.

Entre as definições para a palavra termo, grande parte delas converge para a apresentada por Cabré, segundo a qual "um termo é uma unidade de características linguísticas similares, utilizadas em um domínio de

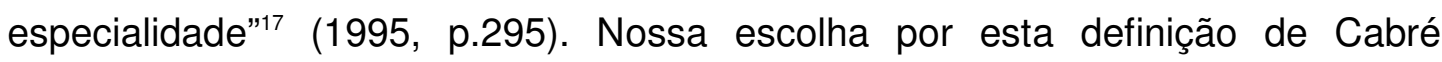
justifica-se não somente pelo reconhecimento dos estudos da autora, mas principalmente por deixar explícito que um termo é composto por características.

Barros define características como se "fossem representações mentais de propriedades do objeto" (2004, p. 107) e devido a sua importância podem ser essenciais a sua definição ou complementares, com pouca ou nenhuma importância para a descrição mínima desse objeto.

A abordagem via características é aplicada de forma que

a identificação, a distinção e a descrição dos diferentes conceitos são feitas por meio de traços de sentido, chamados em Terminologia de características, ou seja, representações mentais de propriedade dos objetos (BARROS, 2004, p. 107).

Em nossa pesquisa trabalharemos com a coleta de conceitos. $\mathrm{Na}$ composição dos conceitos serão identificadas características intrínsecas, inerentes à condição de definição daquele conceito tais como forma, cor grandeza, ou extrínsecas, que podem ser finalidade, origem, emprego, e outras.

A utilização das metodologias de coleta, interpretação, tratamento e apresentação dos dados é entendida como a aplicação prática da Terminologia, tendo diversas finalidades, sejam elas para um sistema linguístico, tradução ou planejamento de uma língua (BARROS, 2004, p.46). Para todas elas é necessária uma análise conceitual, que para Boutin-Quesnel ${ }^{18}$ (citado por BARROS, 2004, p. 106) "determinam as características de um conceito, de sua compreensão, de sua extensão e das relações que o mesmo mantém com os outros conceitos".

Pesquisar as características dos conceitos se justifica ao entender que é por meio delas que podemos analisar diferentes contextos em que os

\footnotetext{
17 Tradução livre do autor.

${ }^{18}$ BOUTIN-QUESNEL, Robert. et al. Vocabulaire systématique de la terminologie. Québec:

Publications du Québec, 1985.
} 
termos aparecem e são aplicados, bem como períodos de surgimento, ápice e declínio de uso. Embora se discuta contemporaneamente sobre a pertinência de considerar as características como representações mentais (LARA, 1999), é indiscutível que o trabalho sobre as características corrobora o diálogo entre terminologia e Ciência da Informação, permitindo operacionalizar a identificação dos conceitos de nossa área (como outras), para chegar a uma visão do seu estágio no momento contemporâneo.

Trazemos à discussão outras definições de linguagem de especialidade com o objetivo de complementar nossa base de argumentos para analisar a linguagem de especialidade da Ciência da Informação. A linguista Ana Maria Maciel, em seu trabalho Linguagens especializadas e terminologia: 0 passado projetando o futuro, traz uma série de definições para linguagem de especialidade, muitas delas traduzidas de textos em francês e alemão, para contextualizar o lugar de sua fala. Algumas dessas definições serão utilizadas nesse trabalho devido a sua aderência ao nosso tema. Um dos autores citados por Maciel (2010, p.9) é Pierre Lerat que define uma língua especializada como

[...] o uso de uma língua natural para dar conta tecnicamente de conhecimentos especializados [...]. A língua especializada é, em primeiro lugar, uma língua em situação de uso profissional (uma 'língua na especialidade' como diz a escola de Praga). É a própria língua como sistema autônomo, mas ao serviço de uma função maior: a transmissão de conhecimentos. (LERAT, 1995, p.221. livre tradução de MACIEL).

Para que possamos complementar ainda mais a questão da especialização das linguagens, trazemos uma classificação proposta por Haruka Nakayama para uma maior compreensão dos aspectos que envolvem

\begin{abstract}
a especialização que caracteriza a língua de especialidade pode-se classificar como: a) conjunto de signos lingüísticos especializados pela temática (assunto, ciência, teoria, princípios, dentre outros); b) conjunto de signos lingüísticos especializados pelas técnicas ou procedimentos: c) conjunto de signos lingüísticos especializados pelo papel social, cultural ou político; d) conjunto de signos lingüísticos especializados pela profissão; e) conjunto de signos lingüísticos especializados pelas experiências e atividades (NAKAYAMA, 1999, P.107).
\end{abstract}

Essas definições possuem em comum, para além do fato de usarem a expressão língua de especialidade como sinônimo para linguagem de especialidade, a indicação objetiva de que seu uso também permeia o ambiente profissional. Em linha com essa colocação propomos que a linguagem de 
especialidade, ao atravessar as camadas do campo científico desde a comunicação entre os pesquisadores até o extremo da atuação profissional, pode auxiliar na consolidação de uma ciência nova, que em virtude da ausência de uma linguagem de especialidade não definida, tenha dificuldade para se impor e ser reconhecida como área do conhecimento.

Um exemplo para essa proposição encontra-se no livro de Andrew Abbott, The system of professions, de 1988, que propõe uma reflexão sobre as profissões como um sistema no qual existem relações conflituosas de espaço e poder entre os limites pertencentes a cada profissão, origem do termo teoria da jurisdição das profissões. Para o autor, pode ser considerada uma definição genérica de profissão como grupos ocupacionais restritos que aplicam conhecimento abstrato em circunstâncias particulares. (ABBOTT, 1988, p. 8).

A teoria da jurisdição pode ser entendida ao analisar as dimensões do trabalho profissional, da reivindicação da jurisdição e do sistema de profissões. Por trabalho profissional, podemos entender implicações, questionamentos e mudanças recorrentes das tarefas executadas por pessoas dentro das relações de trabalho. A reivindicação da jurisdição, realizadas nas arenas da opinião pública, do sistema legal e do mercado de trabalho, ocorre quando um grupo profissional recorre à sociedade que reconheça a detenção e aplicação do conhecimento abstrato pertencente àquele grupo, somente pelos seus participantes formais. E o sistema de profissões é marcado fortemente pelo controle cultural, com origem nas relações de trabalho, e social, com origem na reivindicação da jurisdição, das profissões.

É interessante que abordemos especificamente a questão da reivindicação pela jurisdição, porque no momento em que esta é solicitada existe a necessidade da formulação de propostas e em seu conteúdo aparece a questão da linguagem. Questão esta citada diretamente por Sousa (2007, p.44) ao expor as arenas de reivindicação

A reivindicação de uma jurisdição pode ser realizada em diversas arenas. Uma delas é a arena da opinião pública, em que a profissão requer a exclusividade na condução de uma determinada tarefa, impondo algumas características definidas pela profissão e também requer o direito de excluir outros profissionais. Uma segunda arena é o sistema legal. Nesse caso, o conteúdo da reivindicação da jurisdição é mais específico e inclui o monopólio de certas atividades, certos tipos de 
pagamentos e o controle de algumas características do trabalho. Aqui há também o controle da linguagem utilizada para a condução do trabalho. Outra arena, considerada pelo autor como a menos estudada, é a do mercado de trabalho.

O extremo do uso da linguagem de especialidade para a reivindicação pela jurisdição configura-se na aplicação excessiva do jargão técnico ou científico, conforme nos apresenta Tinka Reichmann como um fator excludente da linguagem especializada ao recomendar a preferência por termos técnicos e não jargões científicos. A autora observa o apontamento dessa realidade por diversos autores ao constatar que

A característica excludente da linguagem especializada, e sobretudo do jargão técnico, foi apontada por Lepenies na área da sociologia (LEPENIES, 1986) e Cais (2004), Menezes (2004) e Souza (2005), entre outros, na área do direito. (LEPENIES, 1986) conclui que o jargão técnico é muita vezes, nada mais que um idioleto cujo objetivo na verdade não é o êxito da comunicação entre especialistas, mas sim a criação de uma aura de mistério em torno do especialista que fortalece seu poder (REICHMANN, 2009, p.112).

\subsection{Aplicações da Terminologia Junto à Ciência da Informação}

No âmbito da Ciência da Informação, a Terminologia é integrada à pesquisa como fonte de método e de técnicas que dão apoio à estruturação das linguagens documentárias. O estudo da Terminologia pela área da $\mathrm{Cl}$ tem seu início nos anos 90, passando a integrar o conjunto das áreas com as quais dialoga para estabelecer seu corpo básico de conhecimentos e procedimentos.

As relações mantidas entre a Terminologia e a Ciência da Informação ultrapassam a utilização das terminologias como referência de domínio para aos produtos terminológicos, ao ser base confiável para seleção e contextualização dos conceitos utilizados em linguagens documentárias. Para Lara e Tálamo (2007) "[... ] diálogo entre a Terminologia e a Lingüística Documentária se realiza no plano teórico e metodológico, não se restringindo, portanto, ao empréstimo pontual dos termos utilizados nas áreas do saber ou de atividade".

Importante referencial teórico para a Ciência da Informação reside nas normas ISO 704 (2000) - que estabelece e harmoniza os princípios básicos e

\footnotetext{
${ }^{19}$ Por ser veiculado em revista exclusivamente digital o artigo não possui paginação.
} 
métodos para a preparação e compilação de terminologias, além de descrever as formas para a realização dos processos de designação e definição - e ISO 1087-1 (2000) que conta com a definição de grande parte dos conceitos apresentados na norma ISO 704 (2000). Ambas devem ser operadas em conjunto por que se complementam e juntas potencializam a produção de sentido.

A definição dos termos deve ser realizada dentro do campo nocional ou conceptual, ou seja, no interior do subconjunto linguístico correspondente ao discurso de especialidade, definindo o conceito através das relações que unem os conceitos. Lembrando que os termos constituem um subconjunto de signos linguísticos relativos a uma área conceitual e são utilizados na comunicação especializada, devendo ser sempre associados a um sistema de conceitos pertinente a determinados domínios de saber ou de atividades.

Além de sua relação com a Linguística Documentária, a Terminologia pode auxiliar a Ciência da Informação fornecendo referenciais teóricos e práticos que possibilitem a consolidação de sua terminologia. Inúmeros estudos em Terminologia trazem à reflexão essa necessidade de que uma ciência se fortalece, delimitando seu campo conceitual, quando estrutura a terminologia empregada nos discursos teóricos e práticos de seus realizadores.

A interdisciplinaridade entre as ciências ocorre de forma não controlada, sendo necessária para os avanços de uma sociedade cada vez mais relacional, com problemas tão complexos e emaranhados que as soluções com base em uma única visão de mundo não são mais eficientes. Ou, como sintetiza Saracevic, em seu estudo sobre a origem, evolução e relações da Ciência da Informação, "problemas complexos demandam enfoques interdisciplinares e soluções multidisciplinares" (1996, p. 48).

Rondeau $^{20}$ citado por Lima (2006) coloca que devido à
necessidade de comunicação entre os cientistas de diversas áreas, a
normalização terminológica teve prioridade

para garantir a comunicação entre os especialistas, seja no interior de uma mesma disciplina, seja entre disciplinas diferentes, ela necessita da padronização dos termos científicos e das micro-especializações das ciências, as quais acentuam a criação de neologismos, isto é, a

${ }^{20}$ RONDEAU, G. Introduction à la terminologie. Chicoutimi: Gaetan Morin, 1984. 
proposição de termos novos ou antigos com nova significação (LIMA, 2006) ${ }^{2 \uparrow}$.

A mesma interdisciplinaridade necessária e profícua ao desenvolvimento humano pode ser uma ameaça aos novos campos científicos, pois estes, por não possuírem, em grande maioria, reflexões avançadas sobre os conceitos que formam o núcleo central da sua identidade científica, são menos reconhecidos perante as ciências mais consolidadas.

Seguindo essa abordagem, Réndon Rojas (2008) afirma que o núcleo central de uma disciplina nos permite salvaguardar a tradição científica, enquanto o cinturão protetor, formado por várias teorias (de cada domínio do saber) que podem mudar, desaparecer ou surgir, nos dá a possibilidade de inovação. Como possibilidade de inovação, encontram-se as relações com outras ciências, possíveis por meio de uma linguagem compartilhada pelos protagonistas de ambos os campos científicos. Faz-se necessário ressaltar que a interdisciplinaridade se processa não somente pelo compartilhamento de linguagens de áreas diferentes, mas pela relação e articulação entre disciplinas. Essa integração disciplinar é expressa com precisão por Olga Pombo em seu trabalho, ao definir que

Por interdisciplinaridade, deverá então entender-se qualquer forma de combinação entre duas ou mais disciplinas com vista à compreensão de um objecto a partir da confluência de pontos de vista diferentes e tendo como objectivo final a elaboração de uma síntese relativamente ao objecto comum. (POMBO, 1991, p.14)

A transição de uma sociedade moderna para a pós-moderna não é abrupta, se desenvolve num processo de assimilação das novas necessidades e adaptação do conhecimento existente a elas, sem a negação total do estabelecido e adoção do novo. Essas classificações são cunhadas por estudiosos do contexto social, comparando o momento atual com o anterior, e é possível que, daqui a alguns anos, esse período histórico-social tenha outra nomenclatura. Porém as características intrínsecas ao processo de transformação serão as mesmas.

Da mesma forma, ocorre com a ciência, que é um produto social. Essa se transforma para adequar-se à nova realidade imposta pela sociedade em

\footnotetext{
${ }^{21}$ A referência encontra-se sem paginação por não ter tido acesso ao texto publicado nos Anais e sim a uma cópia do original recebida da própria autora.
} 
mudança e para acompanhar as tecnologias que possibilitam seu desenvolvimento. O surgimento da Terminologia de Wüster nos anos 1930 e da Ciência da Informação de Bush em meados dos anos 1940 são exemplos claros dessa adaptação das ciências em face da necessidade do surgimento de novos campos do conhecimento para tentar organizar e entender as novas relações que são criadas. 


\section{PROCEDIMENTOS METODOLÓGICOS}

Adotamos para toda a pesquisa o conceito de método científico como "...um conjunto de procedimentos intelectuais e técnicos para que os objetivos [...] sejam atingidos." (GIL, 1999, p.26). Um dos nossos objetivos é a proposta de uma metodologia para análise da linguagem de especialidade em Ciência da Informação. Em face da não existência de uma metodologia única para a obtenção de termos que permitirão análise da linguagem de especialidade de uma área, optamos por trabalhar nesse estudo um método exploratório para a obtenção desses termos.

De maneira geral, os estudos de caráter exploratório possuem o objetivo principal de proporcionar uma maior familiaridade com o fenômeno ou problema a ser pesquisado para que haja melhor compreensão do objeto de estudo. Considerado como um aprimoramento das ideias, o método exploratório permite definir o problema de pesquisa e formular a hipótese com mais precisão, fornecendo uma maior liberdade na escolha das técnicas mais adequadas para a pesquisa e de decisão sobre as questões que devem ser enfatizadas e/ou detalhadas.

Inicialmente, realizou-se pesquisa bibliográfica em fontes de informação impressas e eletrônicas, tais como livros, artigos de periódicos, anais de congressos e seminários, dissertações e teses, normas nacionais e internacionais, portais de conteúdo e outros documentos, para levantamento dos principais estudos e textos referentes às temáticas a serem desenvolvidas na dissertação. Parte dos documentos utilizados para essa pesquisa encontra-se em duplicidade tanto nas fontes impressas, quanto eletrônicas, dando-se preferência pela citação da obra em versão eletrônica, pela facilidade de localização da obra para consulta e por possibilitar o acesso em qualquer ambiente, não restringindo a pesquisa bibliográfica a fontes encontradas apenas nos limites da Universidade. Outros documentos, como alguns textos produzidos por Rafael Capurro, encontram-se disponíveis exclusivamente em endereços eletrônicos, uma tendência observada na contemporaneidade: a virtualização dos acervos. 
A pesquisa bibliográfica abrangeu as temáticas a seguir:

- A constituição da Ciência da Informação, delimitação da área do conhecimento e do objeto de estudo, estudos históricos, epistemológicos e sobre sua terminologia e sua linguagem de especialidade;

- Discussões contemporâneas sobre a constituição da Ciência da Informação e suas características;

- Teorias da Terminologia, seus conceitos e suas aplicações;

- Linguagens de especialidade, suas características e diferenciais.

Dentro da bibliografia levantada foram escolhidos textos que abordam a temática da epistemologia da Ciência da Informação, sua terminologia e sua linguagem de especialidade, bases teóricas da Terminologia e textos que abordavam a relação da $\mathrm{Cl}$ com a Terminologia para a construção do quadro teórico de referência.

Como a produção intelectual na área está em constante crescimento, a pesquisa bibliográfica abrangeu o período até dezembro de 2010, porém somente serão incorporados em nosso corpus de análise os textos que contribuírem significativamente para nossa pesquisa. Tal procedimento se encontra em linha com a afirmação de Stumpf de que "a revisão da literatura é uma atividade contínua e constante em todo trabalho acadêmico e de pesquisa, iniciado com a formulação do problema e/ou objetivos indo até a análise dos resultados" (2010, p.52). 


\subsection{Seleção e Descrição da Amostra}

Definir os critérios para seleção dos termos mostrou-se uma tarefa delicada e complexa. As fontes consultadas para referendar esses critérios para seleção dos termos se concentravam no campo da Terminologia. No processo terminológico e terminográfico trabalha-se com levantamento de termos em quantidade bem diferente da realidade de termos analisados nesse trabalho, girando em torno de mais de mil unidades terminológicas, chegando a 50 mil vocábulos (OLIVEIRA e ISQUERDO, 1998, p. 18) em casos de dicionários de língua. No nosso caso trabalharemos com um universo restrito, tendo que adaptar as teorias da Terminologia à nossa prática.

A delimitação do corpus de coleta, a quantidade e seleção dos termos se apresentaram como umas das maiores dificuldades encontradas, afinal, é com base no retorno dessa seleção e coleta que grande parte da dissertação se sustenta. A escolha dos termos não poderia ser apenas intuitiva, devido minha familiaridade com a área da $\mathrm{Cl}$.

A delimitação do corpus de análise que, conforme Barros “(...) compõe-se dos textos dos quais serão recolhidas as unidades terminológicas que constituirão a nomenclatura (conjunto terminológico em estudo)(..)" (2004, p.202), também se mostrou delicada por ser a base de onde extrairemos os conceitos e se desenvolverá nossa discussão.

Para a identificação dos conceitos, é necessário partir de uma base de termos que compõem o discurso técnico, a linguagem de especialidade, da Ciência da Informação. Como a Ciência da Informação não dispõe de sua terminologia consolidada, faz-se necessária a construção de uma relação de termos para compor essa base. Para essa construção, trabalharemos com as palavras-chaves de artigos de periódicos científicos da área, e como "não existem textos especializados sem termos, por outro lado, uma terminologia fora da linguagem de especialidade não tem razão de ser" (MACIEL, 2010, p. 26). 
Escolhemos como fonte para seleção dos termos os artigos de periódicos devido a estas publicações serem o meio reconhecido para a apresentação de pesquisas científicas, onde são divulgados resultados de pesquisas recentes, aliada a pluralidade de origens e formação dos pesquisadores, de pontos de vistas, de tipos e temáticas de pesquisa, e outros aspectos que enriquecem a diversidade dos discursos, e que podem render mais subsídios para a análise dos nossos resultados.

Para tanto recorremos aos periódicos da área de Ciência da Informação - Ciência da Informação, Perspectivas em Ciência da Informação e Informação \& Sociedade: estudos -, selecionados devido a sua avaliação pela Coordenação de Aperfeiçoamento de Pessoal de Nível Superior - CAPES. Utilizamos o critério de avaliação Qualis, desenvolvido pela CAPES, para a seleção dos periódicos que compõem a amostra devido à credibilidade da metodologia Qualis, que de acordo com sua desenvolvedora

é o conjunto de procedimentos utilizados pela Capes para estratificação da qualidade da produção intelectual dos programas de pós-graduação. Como resultado, disponibiliza uma lista com a classificação dos veículos utilizados pelos programas de pós-graduação para a divulgação da sua produção (2010).

A metodologia Qualis classifica os periódicos em A1, A2, B1, B2, B3, B4, B5 e C conforme a adequação aos critérios ${ }^{22}$ estabelecidos. O corte para a amostra abrangeu os títulos de periódicos da área de Ciência da Informação, que devido à organização da metodologia Qualis encontram-se listados na área de Ciências Sociais Aplicadas 1, que possuem a melhor avaliação. Temos com conceito A2 os periódicos Ciência da Informação e Perspectivas em Ciência da Informação e com conceito B1 o periódico Informação \& Sociedade: estudos, ressaltando que não temos periódicos com o conceito $A 1$ para a área de Ciência da Informação no Brasil. A avaliação apresentada no site refere-se ao ano base 2008.

\footnotetext{
${ }^{22}$ Informações mais detalhadas sobre os critérios Qualis podem ser consultadas no site da CAPES, cujo endereço consta da bibliografia deste trabalho.
} 
Nossa amostra abrangerá os artigos publicados entre os anos de 2005 e 2009 nos três periódicos anteriormente citados, resultando num montante de 338 artigos.

As linhas editoriais dos periódicos que serviram de base para a seleção das palavras são muito semelhantes entre si e a seguir transcreveremos as informações que constam em suas seções sobre Foco e Escopo, comum aos três periódicos.

O periódico Ciência da Informação, editado pelo IBICT-Instituto Brasileiro de Informação em Ciência e Tecnologia desde 1972. Teve periodicidade semestral até o ano de 1991, sendo quadrimestral de 1992 até sua mais recente publicação na data dessa dissertação, em volume 39, número 2 de 2010. Em sua seção Foco e Escopo é auto definida como

\begin{abstract}
uma publicação quadrimestral de trabalhos inéditos relacionados com a Ciência da Informação ou que apresentem resultados de estudos e pesquisas sobre as atividades do setor de informação em ciência e tecnologia. Entende-se por ciência da informação a área interdisciplinar concernente ao estudo dos fenômenos ligados à produção, organização, difusão e utilização de informações em todos os campos do saber. A atividade do setor de informação engloba componentes de vários outros setores e subsetores, como os da educação, cultura e pesquisa, telecomunicações e informática, nos seus aspectos relacionados à informação científica e tecnológica e à tecnologia da informação (IBICT, $s / d)^{23}$
\end{abstract}

Já o periódico Perspectivas em Ciência da Informação, editado pela Escola de Biblioteconomia da Universidade Federal de Minas Gerais, foi lançada em 1996, em substituição à Revista da Escola de Biblioteconomia da UFMG. Possui uma apresentação sua página inicial que relata seu objetivo de "constituir-se em veículo de disseminação do conhecimento científico e de interlocução entre pesquisadores, professores, profissionais e alunos das áreas de Ciência da Informação, Biblioteconomia e áreas afins”, com foco na divulgação de "resultados de pesquisa, trabalhos técnicos e acadêmicos realizados em diversos contextos da informação", sendo "apresentada somente em formato eletrônico, desde 2007, tendo automatizado todo o seu processo de gerenciamento editorial, o que permite a universalidade de acesso a leitores e

\footnotetext{
${ }^{23}$ Fonte: IBICT. Periódico Ciência da Informação, seção Foco e Escopo. Disponível em $<$ http://revista.ibict.br/ciinf/index.php/ciinf/about/editorialPolicies\#focusAndScope>. Acesso em: 10 maio 2011.
} 
potenciais autores" . (UFMG, s/d $)^{24}$. Na seção Foco e Escopo temos as informações que o periódico é

uma publicação quadrimestral da Escola de Ciência da Informação da UFMG. Foi lançada em 1996, em substituição à Revista da Escola de Biblioteconomia da UFMG, com ISSN 0100-0829. Divulga relatos de pesquisa, estudos teóricos, revisões de literatura, textos didáticos, relatos de experiências, traduções e resenhas em Ciência da Informação, Biblioteconomia e áreas afins (UFMG, s/d) ${ }^{25}$

E o periódico Informação \& Sociedade: estudos editado pela Universidade Federal da Paraíba, sob responsabilidade do Programa de PósGraduação em Ciência da Informação, desde 1991. Em sua página inicial, o corpo editorial informa que possui abrangência nacional e internacional, emprega a revisão por pares, "adota uma política editorial de distribuição da produção local de modo a não privilegiar autores internos, conforme pode ser observado nos sumários”, possui a missão de

divulgar trabalhos que representem contribuição para o desenvolvimento de novos conhecimentos em Ciência da Informação, Biblioteconomia e áreas afins, entre pesquisadores, docentes, discentes e demais profissionais, independente de vinculação profissional e local de origem $(\mathrm{UFB}, \mathrm{s} / \mathrm{d})^{26}$

Sua política editorial "está aberta às variadas perspectivas pelas quais os cientistas da informação observam a Informação na Sociedade" e cativam a expectativa de que "os mais diversos relatos de estudos sobre informação, bem como as reflexões e proposições dos cientistas da informação encontrem na revista um espaço de trocas comunicativas." (UFPB, s/d) ${ }^{27}$.

Em sua seção Foco e Escopo temos a indicação do objetivo do perimido, expresso abaixo

tem por objetivo divulgar trabalhos que representam contribuição para o desenvolvimento de novos conhecimentos entre pesquisadores,

\footnotetext{
${ }^{24}$ Fonte: UFMG - ESCOLA DE BIBLIOTECONOMIA,. Periódico Perspectivas em Ciência da Informação, Página inicial. Disponível em <http://portaldeperiodicos.eci.ufmg.br/index.php/pci/index>. Acesso em: 10 maio 2011.

${ }^{25}$ Fonte: UFMG - ESCOLA DE BIBLIOTECONOMIA,. Periódico Perspectivas em Ciência da Informação, seção Foco e Escopo. Disponível em <http://portaldeperiodicos.eci.ufmg.br/index.php/pci/about/editorialPolicies\#focusAndScope> Acesso em: 10 maio 2011.

${ }^{26}$ Fonte: UFPB, PROGRAMA DE PÓS-GRADUAÇÃO EM CIÊNCIA DA INFORMAÇÃO. Periódico Informação \& Sociedade: estudos, Home. Disponível em <http://www.ies.ufpb.br/ojs2/index.php/ies/index>. Acesso em: 10 maio 2011.

${ }^{27}$ Fonte: UFPB, PROGRAMA DE PÓS-GRADUAÇÃO EM CIÊNCIA DA INFORMAÇÃO. Periódico Informação \& Sociedade: estudos, Home. Disponível em <http://www.ies.ufpb.br/ojs2/index.php/ies/index>. Acesso em: 10 maio 2011.
} 
docentes, discentes e profissionais em ciência da informação, biblioteconomia e áreas afins, independente de sua vinculação profissional e local de origem, além de publicar, sistematicamente, os resumos das dissertações aprovadas no PPGCI/UFPB.

\subsection{Processo de Coleta e Registro das Palavras-Chave}

No material analisado referente ao período de 2005 a 2009, foram coletadas as palavras-chave somente da seção "Artigos" dos periódicos Ciência da Informação e Perspectivas em Ciência da Informação e da seção "Artigos de Revisão" do periódico Informação \& Sociedade: estudos. Optamos por essa seleção devido a sua constância em todos os fascículos dos periódicos e por serem comuns aos títulos analisados. Outro ponto observado, e que justifica nossa escolha, é referente às seções que tratam de resenhas de livros ou de dissertações e teses, que por tratarem a obra primária de forma ampla, em grande parte dos casos, não apresentam definições, que são o foco de nossa análise. O mesmo pode ser aplicado aos Editoriais, que apresentam a edição, Estudos de caso ou Relato de experiência, por conterem narrativas peculiares de aplicações, ambientes e produtos/serviços, espaços, ambas seções encontrados em todos os periódicos estudados. As seções que não se aplicavam respectivamente aos três periódicos não foram analisadas.

Além das palavras-chave de cada artigo foi registrado também o título do artigo, juntamente com informações referentes ao ano de edição e número do volume, para facilitar sua posterior localização.

O levantamento das palavras-chave foi realizado em separado para cada título de periódico e unificado em uma tabela com a totalidade das palavras-chave. Todas as informações, bem como as palavras-chave, foram registradas em planilhas de dados totais, onde podemos mensurar a quantidade dos artigos e das palavras-chave coletadas. Cada planilha "geral" deu origem a uma planilha secundária com apenas as palavras-chaves que, em lista, receberam tratamento quanto à tradução das palavras-chaves para o português e adequação entre singular e plural, visando à uniformidade dos dados, porém preservando a palavra-chave original. A planilha "secundária" teve a função de 
organizar os termos em lista para que fossem contabilizadas sua frequência e garantir que todas as palavras-chave coletadas estivessem presentes na lista final.

Para a composição da lista final de palavras-chave, os dados das três planilhas secundárias foram unificados e passaram por critérios de exclusão de palavras-chave que não se referem a conceitos válidos para a nosso objetivo, tais como localização geográfica, substantivos próprios e períodos históricos e/ou temporais.

No período analisado, foram publicados 338 artigos, que juntos continham as 1.538 palavras-chave coletadas. Após a aplicação de critérios que garantissem a uniformização dos dados, obtivemos um total de 913 palavraschave. A lista final das palavras-chaves coletadas, bem como a indicação de sua frequência, consta ao final deste trabalho, no Apêndice A (Lista final de palavraschave coletadas).

Escolhemos o método exploratório de coleta de palavras-chave para nossa pesquisa após identificar em outros trabalhos sobre a terminologia e linguagem de especialidade da Ciência da Informação que a seleção dos termos era realizada nos títulos e resumos de artigos, dissertações e teses, ou no próprio corpus textual dos textos, em sua maioria artigos. Propomos esse caminho com uma via alternativa para identificar os termos e conceitos que compõem a linguagem de especialidade da Ciência da Informação.

Nossa primeira opção para a construção de uma relação de termos a serem coletados seria uma adaptação da Lista dos termos consolidados anexa ao artigo de Smit, Tálamo e Kobashi (2004) que contem 54 termos, obtida a partir de um projeto integrado de pesquisa, apoiado pelo CNPq e concluído em 2002. O projeto também utilizou as teorias e práticas da terminologia para coletar e definir os termos, o que corrobora nossa escolha ao indicar que os termos escolhidos possuem aderência ao campo da Ciência da Informação, tendo sido testados anteriormente, minimizando o risco da escolha de termos pouco expressivos. Antes de obterem os 54 termos as autoras processaram 118 termos, 
extraídos de bibliografia composta por 40 títulos $^{28}$, publicados entre 1970 e 1998. Estes 118 termos sintetizados deram origem à lista base do nosso trabalho.

Porém, identificamos entre os termos apresentados naquele trabalho que, mesmo após uma seleção, não teríamos resultados satisfatórios para o objetivo de nossa pesquisa. Grande parte dos termos refere-se ao universo da Biblioteconomia e Documentação, por questões apresentadas pelas autoras no próprio trabalho, e ainda observou-se uma grande incidência de termos relacionados à temática da organização do conhecimento e representação da informação. Precisávamos de um corpus de retratasse melhor o amplo espectro de disciplinas trabalhadas dentro da Ciência da Informação.

Sendo assim, ao optarmos por um gênero documental homogêneo, os artigos científicos, para compor a base da relação de termos a serem coletados, apostamos que essa escolha facilitaria a manipulação dos dados e proporcionaria uma maior abrangência de temas. Orientamos nossa escolha também pela afirmação de Biojone de que

os periódicos não são porém, os únicos instrumentos utilizados no processo de comunicação cientifica. Outros meios são as publicações resultantes de congresso e reuniões científicas... No entanto, o periódico cientifico é, indiscutivelmente o mais utilizado para a publicação dos resultados de pesquisa em todos as áreas do conhecimento (BIOJONE, 2003, p.16).

Definimos as palavras-chave que seriam trabalhadas de acordo com sua frequência, no caso, até 5 (cinco) ocorrências. Acreditamos que esta limitação favoreceu o trabalho de coleta dos termos e a análise dos dados produzidos, escolha essa ancorada na afirmação de Lozano ${ }^{29}$, citado por Fonseca Júnior (2010, p. 292) de que "a definição do tamanho da amostra também depende da disponibilidade de recursos humanos, econômicos e temporais". Para nós a delimitação da quantidade de palavras-chave promoveu uma discussão mais consistente dos resultados, no sentido de que com uma amostra menor pode-se realizar uma análise qualitativa mais aprofundada.

\footnotetext{
${ }^{28}$ Sendo 15 obras de referência e 25 fontes bibliográficas distribuídas dentre 9 livros e 16 artigos de periódicos.

${ }^{29}$ LOZANO, José. Hacia la reconsideración del análisis de contenido en la investigación de los mensajes comunicacionales. In: RUIZ, E. S; BARBA, C.C. (org). Investigar la Comunicación. CEIC/universidad de Guadalajara/ALAIC. México, 1994. p. 135-157.
} 
Ao final da seleção por frequência foram analisadas 39 (trinta e nove) palavras-chave, apresentadas na tabela a seguir:

TABELA 1: Lista de palavras-chave analisadas em relação a sua frequência

\begin{tabular}{|c|c|c|c|}
\hline Palavra-chave & Frequência & Palavra-chave & Frequência \\
\hline Ciência da Informação & 41 & Inclusão digital & 7 \\
\hline Gestão do conhecimento & 30 & Inteligência competitiva & 7 \\
\hline Comunicação científica & 21 & Arquivos abertos & 6 \\
\hline Informação & 20 & Produção científica & 6 \\
\hline Gestão da informação & 19 & Redes sociais & 6 \\
\hline Bibliometria & 18 & Sistema de informação & 6 \\
\hline Competência informacional & 11 & Acesso aberto & 5 \\
\hline $\begin{array}{l}\text { Tecnologia da informação e } \\
\text { comunicação }\end{array}$ & 11 & Biblioteca universitária & 5 \\
\hline Biblioteca digital & 10 & Biblioteconomia & 5 \\
\hline Internet & 10 & Ciberespaço & 5 \\
\hline Profissional da informação & 10 & Indicadores & 5 \\
\hline Sociedade da informação & 10 & Informação científica & 5 \\
\hline Biblioteca & 8 & Interdisciplinaridade & 5 \\
\hline Bibliotecário & 8 & Ontologia & 5 \\
\hline Conhecimento & 8 & $\begin{array}{l}\text { Organização do } \\
\text { conhecimento }\end{array}$ & 5 \\
\hline Fonte de informação & 8 & Periódico científico & 5 \\
\hline Informetria & 8 & Produtividade de autores & 5 \\
\hline $\begin{array}{l}\text { Aprendizagem } \\
\text { organizacional }\end{array}$ & 7 & Publicação eletrônica & 5 \\
\hline Biblioteca escolar & 7 & Qualidade da informação & 5 \\
\hline Cientometria & 7 & & \\
\hline
\end{tabular}




\subsection{Processo das Aplicações das Palavras-Chave}

Após a definição da lista de palavras-chaves analisamos a aplicação de cada palavra-chave em momentos distintos do artigo:

1. Ocorrência da palavra-chave no resumo;

2. Ocorrência da palavra-chave no texto do artigo;

3. Conceituação ou definição da palavra-chave no texto do artigo.

Esses dados foram registrados na planilha "geral" de cada periódico, a mesma utilizada para a coleta das palavras-chave.

Quando a palavra-chave possuía conceituação ou definição, foi realizada a transcrição do trecho, utilizando as práticas terminológicas, em fichas de coleta terminológica ${ }^{30}$, criadas especificamente para essa finalidade. Nossa pesquisa segue em linha com o trabalho da pesquisadora da FFLCH/USP, Profa. Dra. Maria Aparecida Barbosa, (2001, p.76-77) ao propor que "Conceituar é o processo de construção de um modelo mental que corresponde a um recorte cultural e, em seguida, de escolha/engendramento da estrutura léxica que pode manifestá-lo de maneira mais eficaz." e que "definir é o processo de analisar e descrever o semema lingüístico, para reconstruir o modelo mental: o seu ponto de partida é a estrutura lingüística manifestada." (BARBOSA, 2001, p.77). O registro das definições de cada palavra-chave foi descrito identificando as diferentes fontes e contexto de extração dos conceitos.

\footnotetext{
${ }^{30}$ Ver modelo no Apêndice I - Modelo de Ficha de Coleta Terminológica
} 


\section{RESULTADOS E DISCUSSÕES}

Nossa pesquisa resultou da análise da incidência das palavraschave contidas nos artigos de seções específicas dos periódicos Ciência da Informação, Perspectivas em Ciência da Informação e Informação \& Sociedade: estudos, no período de 2005 a 2009. Como as justificativas para a seleção dos periódicos, os critérios de segmentação das seções e a descrição de todas as etapas de coleta e registro dos dados foram relatadas anteriormente no Capítulo 4, Procedimentos Metodológicos, o presente capítulo restringe-se à apresentação e análise dos dados encontrados.

Primeiramente, os resultados serão apresentados por meio de gráficos, tabelas e quadros, a fim de facilitar a visualização e compreensão dos dados. Seguindo essa orientação, utilizaremos sempre a mesma cor para representar o mesmo título de periódico em todos os gráficos, quadros e tabelas que contenham dados comparativos entre os três títulos.

Posteriormente, teremos a análise geral dos dados, seguida de discussão direcionada para a questão central de nossa pesquisa, a linguagem de especialidade da Ciência da Informação. As subdivisões deste capítulo foram organizadas de modo a apresentar as constatações das palavras-chave que possuíam uma definição do conceito no corpo do texto ao qual a palavra-chave está relacionada, e a problemática das palavras-chave sem definição do conceito no corpo do texto.

Antes mesmo da coleta terminológica e da sintetização dos conceitos, observamos recorrência de palavras-chave ligadas ao campo da Biblioteconomia e, em menor incidência, da Documentação. Surpreende-nos a grande ocorrência de palavras-chave ligadas à gestão empresarial tais como cultura organizacional e inteligência competitiva, e relacionadas às métricas, tais como a bibliometria e à mensuração de produção científica através da cienciometria e da webmetria. 
Durante a análise das palavras-chave do periódico Ciência da Informação, observamos maior ocorrência de palavras-chave ligadas à bibliometria e mensuração de produção científica, bem como sobre gestão empresarial, iniciativas de arquivos abertos (open archives) e usos de tecnologias da informação e comunicação. Um diferencial desse periódico é que, em sua seção Foco e Escopo, a equipe editorial conceitua Ciência da Informação como "área interdisciplinar concernente ao estudo dos fenômenos ligados à produção, organização, difusão e utilização de informações em todos os campos do saber"(IBICT, s/d) ${ }^{31}$, não encontrando similar nas respectivas seções dos outros periódicos analisados.

Para o periódico Perspectivas em Ciência da Informação, constatou-se maior ocorrência de palavras-chaves ligadas à gestão empresarial, administração de unidades de informação e bibliometria, seguidas por usos de tecnologias da informação e comunicação, iniciativas de arquivos abertos e organização e representação da informação e conhecimento.

Tal tendência não se verifica nas palavras-chaves retiradas do periódico Informação \& Sociedade: estudos. Com um mais expressivo equilíbrio entre as palavras-chaves, excluindo a temática de gestão empresarial e usos de tecnologias da informação e comunicação, observamos maior incidência de temas que remetem às ciências humanas e sociais, comunicação, educação, ação e mediação cultural e outros.

Está claro para nós que a seleção dos periódicos influenciou o resultado alcançado. Porém, é necessário que a escolha estivesse embasada por critérios claros e objetivos. O período de corte para a coleta também reflete um momento social e histórico marcado por crises, que geram uma maior necessidade de justificativa para escolhas e avaliação do que está consolidado, evidenciando uma quantidade considerável de artigos sobre mensuração de resultados tanto de unidades de informação físicas, quanto de sistemas virtuais de armazenamento e recuperação de informação, incluindo as métricas para

\footnotetext{
${ }^{31}$ Fonte: IBICT. Periódico Ciência da Informação, seção Foco e Escopo. Disponível em <http://revista.ibict.br/ciinf/index.php/ciinf/about/editorialPolicies\#focusAndScope>. Acesso em: 10 maio 2011.
} 
avaliação de produção científica de autores institucionais e de divulgação em periódicos especializados.

Retomamos os números apresentados no capítulo anterior para que possamos melhor analisá-los e compará-los entre si, bem com apresentá-los de forma detalhada e referenciada, lembrando que no período analisado, entre 2005 e 2009, foram publicados 338 artigos. A periodicidade do título Ciência da Informação manteve-se inalterada, sendo publicado quadrimestralmente, o que não ocorreu com os títulos Perspectivas em Ciência da Informação e Informação \& Sociedade: estudos. Até 2005 o periódico Perspectivas em Ciência da Informação era semestral, possuindo periodicidade quadrimestral desde 2006, e o periódico Informação \& Sociedade: estudos tinha periodicidade semestral até o ano de 2006, passando para quadrimestral em 2007.

Os três quadros a seguir indicam a quantidade de artigos por edição e ano em cada título de periódico pesquisado. Pelos quadros podemos perceber as alterações de periodicidade das edições, bem como a quantidade de artigos por edição.

QUADRO 1: Quantidade de artigos por edição e por ano da publicação Ciência da Informação

\begin{tabular}{|c|c|c|c|c|c|}
\hline Edição & 2005 & 2006 & 2007 & 2008 & 2009 \\
\hline No 1 & 10 & 9 & 13 & 9 & 9 \\
\hline No 2 & 9 & 11 & 9 & 8 & 6 \\
\hline No 3 & 2 & 18 & 7 & 6 & 10 \\
\hline Total & 21 & 38 & 29 & 23 & 25 \\
\hline & & \multicolumn{2}{|c|}{ Total gera } & 136 & artigos \\
\hline
\end{tabular}

QUADRO 2: Quantidade de artigos por edição e por ano da publicação Perspectivas em Ciência da Informação

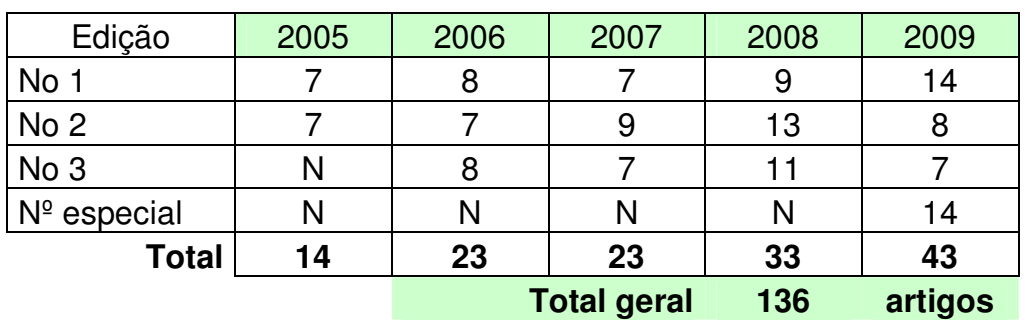

Nota: a letra $\mathrm{N}$ no quadro acima representa a não existência de edição no referido ano. 
QUADRO 3: Quantidade de artigos por edição e por ano da publicação Informação \& Sociedade: estudos

\begin{tabular}{|c|c|c|c|c|c|}
\hline Edição & 2005 & 2006 & 2007 & 2008 & 2009 \\
\hline No 1 & 3 & 7 & 5 & 5 & 5 \\
\hline No 2 & 3 & 6 & 4 & 9 & 3 \\
\hline No 3 & $\mathrm{~N}$ & $\mathrm{~N}$ & 7 & 6 & 3 \\
\hline \multirow[t]{2}{*}{ Total } & 6 & 13 & 16 & 20 & 11 \\
\hline & & \multicolumn{3}{|c|}{ Total geral } & artigo: \\
\hline
\end{tabular}

Nota: a letra $\mathrm{N}$ no quadro acima representa a não existência de edição no referido ano.

Pudemos observar que ocorreu uma coincidência entre a quantidade de artigos levantados nos periódicos Ciência da Informação e Perspectivas em Ciência da Informação, 136 artigos em cada periódico. Somados aos 66 artigos do periódico Informação \& Sociedade: estudos resultam nos 338 artigos que tiveram suas palavras-chave coletadas.

\section{GRÁFICO 1: Quantidade de artigos por título de periódico}

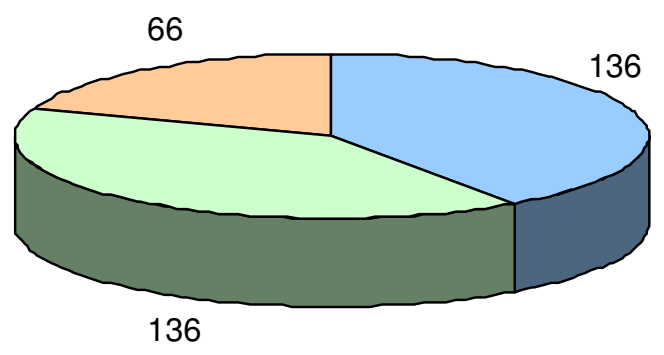

$\square$ Ciência da Informação

$\square$ Perspectivas em Ciência da Informação

$\square$ Informação \& Sociedade: estudos

Em relação às palavras-chaves coletadas, temos dois dados que são relevantes: os 338 artigos continham as 1.538 palavras-chave que deram origem a uma lista inicial. Nessa lista, aplicamos critérios para garantir a uniformização dos dados e ao final obtivemos um total de 913 palavras-chave que seriam analisadas conforme sua frequência. Todos os critérios utilizados para a uniformização e exclusão das palavras-chave estão descritos no item 4.2 - 
Processo de coleta e registro das palavras-chave, no capítulo 4, Procedimentos metodológicos.

Em relação às 913 palavras-chaves analisadas, no geral a média de palavras-chave por artigo foi de 4,6, sendo que o mínimo de palavras-chave encontrada por artigo foram duas, com ocorrência em todos os periódicos, e o máximo de 16 palavras em um artigo do periódico Ciência da Informação. Em nenhum dos periódicos consultados existe orientação quanto à quantidade de palavras-chave mínimas que devem constar no artigo, apenas orientações referentes à questão da tradução para o inglês, assim como o resumo. Também não é disponibilizada lista prévia com palavras-chave que o autor poderia atribuir a seu artigo, facilitando assim a pesquisa do usuário, que se utilizaria dos conteúdos pré-existentes, possibilitando maior probabilidade de eficácia no retorno de sua busca.

Apesar da quantidade de artigos analisados nos periódicos Ciência da Informação e Perspectivas em Ciência da Informação serem iguais, 136 artigos, a distribuição das palavras-chave não se manteve igual, sendo 668 palavras-chave no periódico Ciência da Informação e 581 palavras-chave em Perspectivas em Ciência da Informação. Como esperado, para o periódico com menos artigos, no título Informação \& Sociedade: estudos, encontramos uma menor quantidade de palavras-chave, sendo 289. 
O gráfico abaixo mostra essa proporção, onde o círculo menor representa a quantidade de artigos e o "círculo" maior demonstra a quantidade de palavras-chave em cada título.

GRÁFICO 2: Quantidade de palavras-chaves, em relação a quantidade de artigos por título de periódico

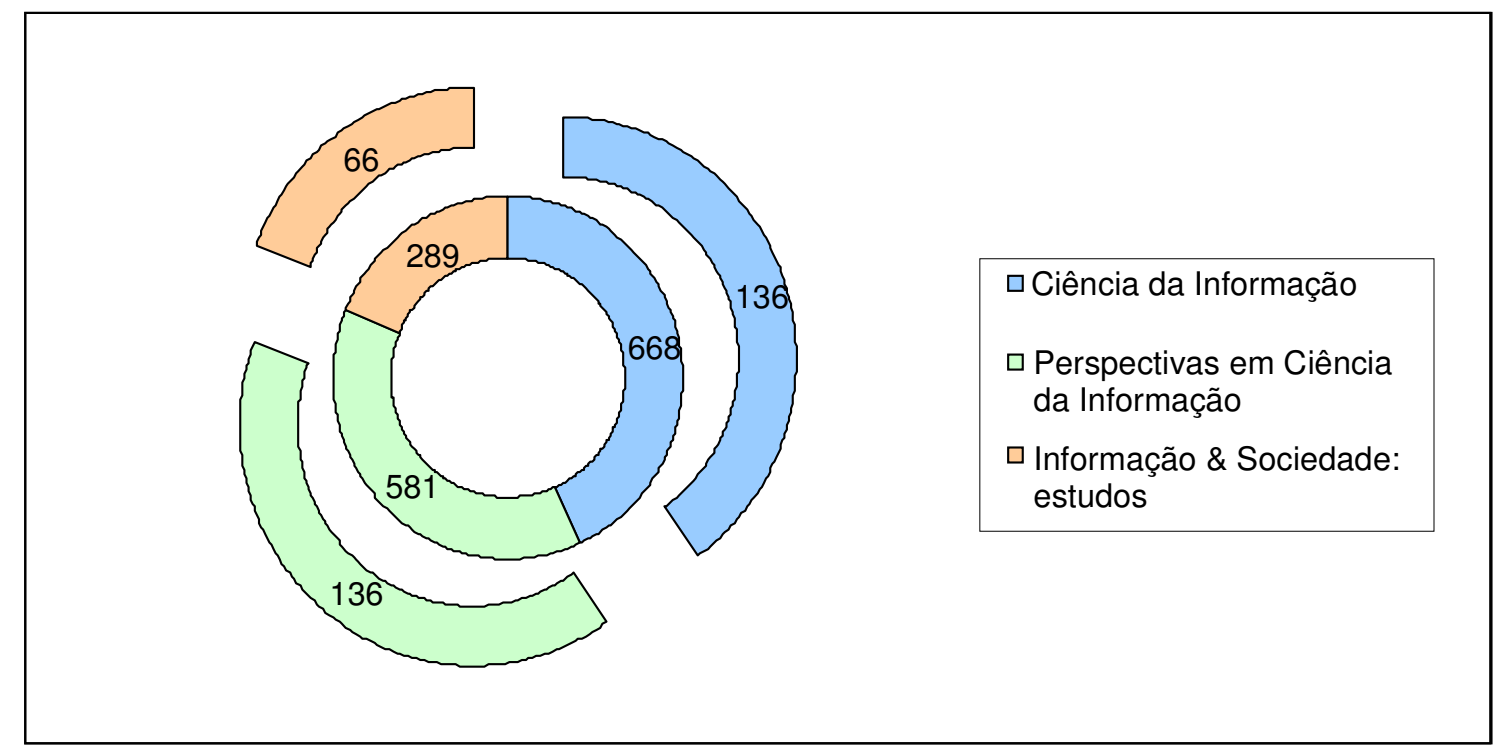

Mesmo com um resultado quantitativamente alto, em torno de 4,6 palavras-chave por artigo em média, o retorno qualitativo, a nosso ver, não foi tão diversificado. Obtivemos 721 palavras-chaves com apenas uma ocorrência, abrangendo todas as áreas da Ciência da Informação, bem como outros campos do conhecimento como Arquivologia, Museologia, Administração, Tecnologia da Informação, Psicologia, Estatística e outras ciências com as quais a Ciência da Informação dialoga em sua tão discutida interdisciplinaridade. Qual a representatividade dessa palavra-chave na linguagem de especialidade da Ciência da Informação?

As palavras-chave de maior frequência foram Ciência da Informação (40 ocorrências), Gestão do conhecimento (30 ocorrências), Comunicação científica (21 ocorrências), Informação (20 ocorrências), Gestão da informação (19 ocorrências), Bibliometria (18 ocorrências), Competência informacional (11 ocorrências), Tecnologia da informação e comunicação (11 ocorrências), Biblioteca digital (10 ocorrências), Internet (10 ocorrências), Profissional da informação (10 ocorrências) e Sociedade da informação (10 
ocorrências). Como teríamos um pequeno corpus para análise, decidimos ampliar a seleção para as palavras-chave com frequência até 5 (cinco) ocorrências.

Para que possamos elevar a discussão ao patamar das linguagens de especialidade, não poderíamos tratar somente no âmbito de palavras-chave, por mais representativas e diversificadas que possam ser. Precisamos transformar essas palavras-chaves em termos, que são a menor unidade das linguagens de especialidade. Segundo Gouadec ${ }^{32}$ citado por Krieger (2001, p.121) "um termo é uma unidade linguística que designa um conceito, um objeto ou um processo" sendo assim tornou-se necessário que verifiquemos no corpo do texto do artigo que continha a palavra-chave se a mesma possuía algumas das três características acima para ser atribuída como um termo.

Foram selecionadas, conforme critério explícito no item 4.2 Processo de coleta e registro das palavras-chave, 39 palavras-chaves que passaram por um processo de verificação de sua ocorrência no resumo do artigo, ocorrência no texto do artigo e, caso aparecesse no texto do artigo deveria ser registrado a existência ou não de conceituação ou definição da palavra-chave. Tal procedimento mostrou-se muito rico em relação a percepção dos níveis de conceituação ou definição, em muitos casos apenas traços de conceito, características remetendo a origem, uso ou função pertencentes ao termo.

Esse trabalho teve como resultado a ausência de conceituação ou definição de 6 palavras-chaves. As outras 33 palavras-chaves possuem algum grau de conceituação ou definição, que culminam com a descrição completa do conceito ao qual elas remetem.

Após a apresentação de algumas considerações acerca dos dados encontrados, adentraremos na análise das palavras-chaves sem e com descrição do conceito, análise essa cerne de nossa pesquisa.

\footnotetext{
${ }^{32}$ GOUADEC, Daniel. Terminologie: constituition des données. Paris: AFNOR, 1990.
} 


\subsection{Palavras-Chave Sem Descrição do Conceito}

As seis palavras-chave que, em nossa análise, não possuem traços ou características que as configuram como termo são apresentadas a seguir: Tecnologia da informação e comunicação (11 ocorrências), Cientometria, (7 ocorrências), Produção científica (6 ocorrências), Sistema de informação (6 ocorrências), Produtividade de autores (5 ocorrências) e Publicação eletrônica (5 ocorrências).

Tais palavras-chaves estão relacionadas no Dicionário de Biblioteconomia e Arquivologia produzido por Murilo Cunha e Cordélia Cavalcanti, ora como verbetes inteiros, ora como parte de verbetes, assimilando que o termo "parte" pode ser entendido como "tipo de". Em face na inexistência de obras de referência em Ciência da Informação em língua portuguesa, utilizaremos o Dicionário de Biblioteconomia e Arquivologia como base para coleta de definições dos conceitos que iremos discutir. A escolha se justifica ainda por ser uma obra relativamente recente, editada em 2008, estar em língua portuguesa (o que minimiza distorções decorrentes de traduções), produzida por autores com renomada experiência e trajetória no campo da Ciência da Informação e apresentar definições para todas as palavras-chaves que não apresentaram traços ou características que as configuram como termo, utilizaremos essa obra como base para nossa discussão sobre essa questão, abrangendo termos utilizados também pela área.

As ocorrências da palavra-chave Tecnologia da informação e comunicação estão relacionadas, em sua maioria, a estudos e relatos de dispositivos digitais para disseminação da informação e promoção de comunicação na internet. Apesar de apresentar 11 ocorrências, em nenhuma delas encontramos traços ou características que poderiam auxiliar a configurarmos a palavra-chave como um termo. Encontra-se associada às palavras-chave Inclusão digital e a Sociedade da Informação, ambas selecionadas e que possuem descrição do conceito. 
Existe uma entrada no Dicionário de Biblioteconomia $e$ Arquivologia para Tecnologias da informação e comunicação remetendo a Tecnologia da Informação. Tecnologia da Informação é uma parte de verbete Tecnologia, e segundo as três definições pode ser entendida como um "tipo de" Tecnologia. A terceira definição, "Produto da convergência das tecnologias da computação e comunicação" (CUNHA e CAVALCANTI, 2008, p.356) seria a que mais se aproxima do contexto em que a palavra-chave Tecnologia da informação e comunicação foi usada nos artigos.

As ocorrências da palavra-chave Cientometria estão sempre relacionadas a estudos sobre a mensuração de produtividade seja de autores, de instituições ou de eventos científicos relacionados a uma instituição acadêmicacientífica ou a revisão de literatura desse campo. Das sete ocorrências, cinco estão relacionadas com palavras-chave como Bibliometria, Infometria e quatro com a palavras-chave Produtividade de autores, que também não possui traços ou características que as configuram como termo.

Vale à pena destacar que, dentre as palavras-chaves analisadas, encontramos a palavra-chave Cienciometria. Essa não foi considerada como variação de Cientometria, pois para tanto teríamos que verificar a conceituação ou definição de ambas aplicadas nos textos. Diante da quantidade de palavras-chave esta conferência não pode ser realizada, mas configura-se também como outra forma de estudo da linguagem de especialidade da Ciência da Informação, os sinônimos ou pequenas variações de escrita. Existe uma indicação na entrada Cienciometria remetendo ao verbete Cientometria no Dicionário de Biblioteconomia e Arquivologia (CUNHA e CAVALCANTI, 2008, p. 81).

No referido Dicionário, o verbete Cientometria possui a seguinte descrição: "Disciplina que tem por objetivo "medir as atividades de pesquisa científica e tecnológica (PCT) mediante insumos (mão de obra, investimentos) e produtos (equipamentos, produtos, publicações; a ICT)" (CUNHA e CAVALCANTI, 2008, p. 81) e está relacionado à análise de citações e bibliometria. Essa relação pode ser comprovada em nossa pesquisa, pois em cinco das sete ocorrências, a palavra-chave aparece relacionada à Bibliometria, palavra-chave também selecionada e que possui descrição do conceito. 
A palavra-chave Produção científica, em grande parte das ocorrências, está relacionada a artigos sobre levantamentos e análises de temas e conteúdos de títulos de periódicos científicos, artigos científicos, dissertações e teses. Em uma das ocorrências, refere-se ao texto que analisa a temática da responsabilidade ética e social na produção de periódicos científicos. Todas as ocorrências estão presentes no periódico Perspectivas em Ciência da Informação, dividindo espaço com as palavras-chaves Comunicação científica e Informação científica, ambas palavras-chaves com descrição do conceito. Já nos títulos Ciência da Informação e Informação \& Sociedade: estudos encontramos apenas as palavras-chave Comunicação Científica e Informação Científica.

O verbete Produção científica é descrito no Dicionário de Biblioteconomia e Arquivologia como "volume de documentos gerados, onde se encontram registradas e disseminadas as descobertas numa área da ciência" (CUNHA e CAVALCANTI, 2008, p. 294).

Apresentamos os conceitos de Comunicação científica e Informação científica de acordo com o Dicionário de Biblioteconomia e Arquivologia para embasar nossa análise. Por Comunicação científica temos o "conceito proposto por John Bernal, no final do anos trinta, para designar o processo específico de produção, consumo e transferência de informação no campo científico" (CUNHA e CAVALCANTI, 2008, p. 97) e Informação científica, com duas acepções sendo a primeira, como "informação decorrente de uma comunicação científica" e a segunda acepção relativa a "informação restrita a comunicação científica" (CUNHA e CAVALCANTI, 2008, p. 203). Na análise das respectivas entradas no referido Dicionário, observamos que Comunicação científica seria um processo mais amplo de atividades associadas à produção, disseminação e uso da informação, e Informação Científica seria um "tipo de" Informação, um qualificador que a diferencia. No referido Dicionário ambas estão subordinadas a uma entrada maior, podendo ser entendidas como um "tipo de": Comunicação, para Comunicação científica e Informação, para Informação científica. 
As ocorrências da palavra-chave Sistema de informação estão associadas, na maioria dos casos, a locais, físicos ou não, órgãos ou departamentos que realizam atividades de organização e disseminação de informação, sendo uma ocorrência a temática de softwares para organização da informação e redes. Encontra-se descrita no Dicionário de Biblioteconomia e Arquivologia como parte do verbete Sistema, que possui oito páginas, com duas acepções sendo uma ligada à administração de bibliotecas "um grupo lógico de subsistemas e dados ou informação, necessários para suprir as necessidades de informação de uma comunidade, grupo ou processo" e outra à informática "uma série de elementos ou componentes inter-relacionados que coletam (entrada), manipulam e armazenam (processo), disseminam (saída) os dados e informações e fornecem um mecanismo de feedback" (CUNHA e CAVALCANTI, 2008, p. 344). Está relacionada também as palavras-chave Gestão do conhecimento e Gestão da informação, apresentando uma ocorrência com cada, ambas palavras-chave com descrição do conceito.

O comportamento das ocorrências da palavra-chave Produtividade dos autores é similar ao da palavra-chave Cientometria, estando presente em todas as ocorrências em artigos que retratam a temática da mensuração de produtividade seja de autores relacionados a uma instituição acadêmica-científica ou análise das temáticas veiculadas em periódicos científicos. É citada no Dicionário de Biblioteconomia e Arquivologia como parte do verbete Produtividade, novamente com a indicação de um "tipo de", como sendo o "número de documentos produzidos por um autor em determinado período" (CUNHA e CAVALCANTI, 2008, p. 294).

E, por último, analisaremos as ocorrências da palavra-chave Publicação eletrônica, que se apresentam em temáticas diversas. Está relacionada a artigos sobre formas de organização da informação, desenvolvimento de publicações eletrônicas, serviços de referência via internet e acesso aberto a publicações científicas, sempre ligada às temáticas de ambientes em rede que se manifestam em ambientes virtuais, eletrônicos, que se configuram somente com o uso de equipamentos que materializam essas redes, interfaces. No Dicionário de Biblioteconomia e Arquivologia é citada como parte do verbete 
Publicação, como um "tipo de", e refere-se a "documento disseminado sob a forma legível por máquina" (CUNHA e CAVALCANTI, 2008, p. 302). Em três ocorrências encontra-se concomitantemente a palavra-chave Comunicação científica, palavra-chave com descrição do conceito.

Dentre as seis palavras-chave que não possuem traços ou características que as configuram como termo, todas estão, de alguma forma, associadas à disseminação da produção científica, tanto nos tradicionais meios de comunicação, como o periódico impresso, como em iniciativas de arquivos abertos ou repositórios digitais de publicações. Sendo assim, podemos conferir que a informação científica e tecnológica concentra grandes esforços em pesquisa na área. Indagamo-nos se tais conceitos já são de tal forma claros para os pesquisadores e consumidores desse tipo de informação, que não se faz necessário sua conceituação ou definição. 


\subsection{Palavras-Chave com Descrição do Conceito}

As 33 palavras-chave que apresentam traços ou características que as configuram como termo estão apresentadas na tabela abaixo, em relação a sua frequência de ocorrência nos artigos:

TABELA 2: Lista de palavras-chave que apresentam traços ou características que as configuram como termo

\begin{tabular}{|l|c|l|c|}
\hline \multicolumn{1}{|c|}{ Palavra-chave } & Frequência & \multicolumn{1}{c|}{ Palavra-chave } & Frequência \\
\hline Ciência da Informação & 41 & Biblioteca escolar & 7 \\
\hline Gestão do conhecimento & 30 & Inclusão digital & 7 \\
\hline Comunicação científica & 21 & Inteligência competitiva & 7 \\
\hline Informação & 20 & Arquivos abertos & 6 \\
\hline Gestão da informação & 19 & Redes sociais & 6 \\
\hline Bibliometria & 18 & Acesso aberto & 5 \\
\hline Sociedade da informação & 12 & Biblioteca universitária & 5 \\
\hline Competência informacional & 11 & Biblioteconomia & 5 \\
\hline Biblioteca digital & 10 & Ciberespaço & 5 \\
\hline Internet & 10 & Indicadores & 5 \\
\hline Profissional da informação & 10 & Informação científica & 5 \\
\hline Biblioteca & 8 & Interdisciplinaridade & 5 \\
\hline Bibliotecário & 8 & Ontologia & 5 \\
\hline Conhecimento & 8 & $\begin{array}{l}\text { Organização do } \\
\text { conhecimento }\end{array}$ & 5 \\
\hline Fonte de informação & 8 & Periódico científico & 5 \\
\hline Informetria & 8 & Qualidade da informação & 5 \\
\hline $\begin{array}{l}\text { Aprendizagem } \\
\text { organizacional }\end{array}$ & 7 & & \\
\hline
\end{tabular}

Todas as palavras-chave com alta frequência apresentam traços ou características que as configuram como termo, evidenciando que na maioria dos artigos, os autores, mesmo que em diferentes graus, mostraram preocupação de conceituar ou definir o que o termo representa dentro do contexto da área.

A palavra-chave com maior frequência foi Ciência da Informação, com 41 ocorrências. Dessas 41 ocorrências, 22, quase a metade, quando continham a palavra-chave no texto não apresentavam traços ou características que as configuram como termo. Do total das ocorrências, 12 não possuíam a palavra-chave no resumo do artigo, dentre as quais oito ocorrências continham a 
palavra-chave no texto, e 4 com apresentavam traços ou características que as configuram como termo. Entre as outras 18 ocorrências encontramos situações diversas de definição ou conceituação de Ciência da Informação.

Algumas apresentavam definições bem completas e outras apenas traços ou características. Foi observada a existência concomitante de palavras-chave Gestão do conhecimento e Gestão da informação com Ciência da informação. Uma das hipóteses para essa aproximação é a de que o autor do artigo as usa como sinônimos para reforçar a busca, ao inferir que o usuário que busca por uma palavra-chave não saiba a diferença conceitual entre os termos. Reforçamos essa proposição ao observarmos, em alguns casos, que apenas uma das duas palavras-chave possui traços ou características que as configuram como termo.

Descreveremos apenas o comportamento dos dados da palavrachave Ciência da informação como um exemplo simbólico, e a selecionamos não somente por ser a de maior frequência e por denominar a campo científico ao qual faz parte essa pesquisa, mas por representar com propriedade o comportamento das outras palavras-chave analisadas. Houve uma pequena variação, em torno de $10 \%$ para mais ou para menos, em relação ao percentual de existência de traços ou características que as configuram como termo.

A soma de todas as ocorrências das 33 palavras-chave que possuem traços ou características que as configuram como termo é de 335. Dentre as 335 ocorrências, 170 são citadas no texto e possuem traços ou características que as configuram como termo e as outras 165 ocorrências não. Encontramos uma proporção bem equilibrada ao apresentarmos os dados em porcentagem: temos $51 \%$ de palavras-chave que possuem traços ou características que as configuram como termo e $49 \%$ de palavras-chave sem indicação de traços ou características que as configuram como termo.

Essa proporção indica que quase metade das ocorrências das palavras-chave, quando citadas no texto, não apresenta qualquer indicação do contexto semântico em que ela se insere. O termo, quando usado para expressão de conceito, quando não seguido de definição pode remeter a diversos campos do conhecimento e não apenas ao campo da Ciência da Informação. Quando o 
termo possui origem em outro campo do conhecimento e é aplicado aos textos sem nenhuma orientação do seu significado para a $\mathrm{Cl}$, entendemos que houve uma apropriação direta. Se houver adaptação ou ressignificação do termo pelo autor em seu texto, e o mesmo não o complementou com traços ou características que permitissem sua identificação clara, o leitor não terá como saber.

Ressaltamos que existem palavras-chave para as quais, mesmo com alta frequência, como no caso de Tecnologia da informação e comunicação, com 11 ocorrências, não foi encontrado nos textos dos artigos nenhum traço ou características que as configuram como termo. Se incluirmos na análise de proporção entre palavras-chave que possuem traços ou características que as configuram como termo as 42 de ocorrências das palavras-chave não possuem traços ou características a proporção de palavras-chave sem conceitos sobre para $62 \%$.

\section{GRÁFICO 3: Proporção entre palavras-chave que possuem traços ou características que as configuram como termo e as que não possuem}

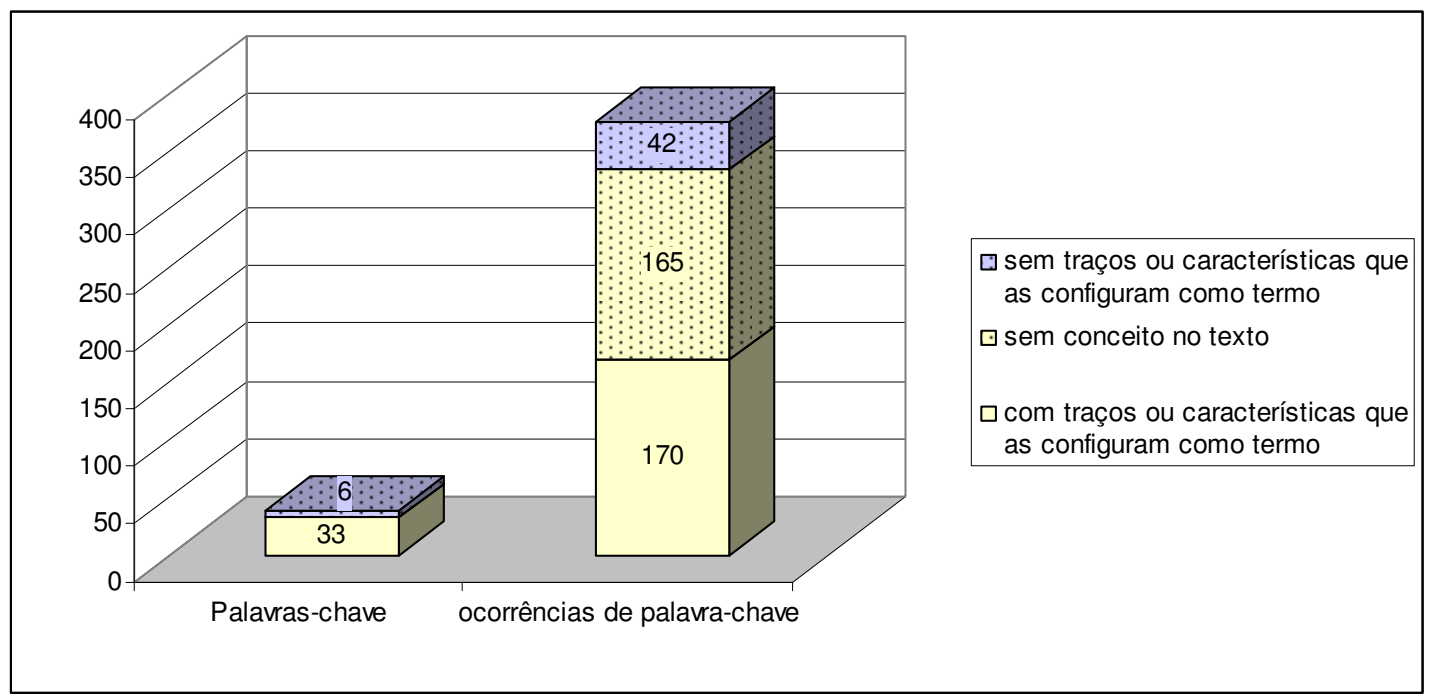

Sobre o Gráfico 3, esclarecemos que a parte mediana do gráfico, preenchida em pontilhado, refere-se às ocorrências das palavras-chave que não possuem traços ou características que as configuram como termo, que somadas às 42 ocorrências das palavras-chaves que não possuem traços ou 
características que as configuram como termo, configuram 207 ocorrências, ou $62 \%$.

Conforme encontramos base na literatura sobre linguagem de especialidade, a comunicação entre participantes de uma comunidade de prática é permeada por termos que são compartilhados pela área do conhecimento ao qual pertencem seus falantes. Esta linguagem partilhada entre os emissores e receptores das mensagens é carregada de significados que, muitas vezes, só possuem significado dentro desta comunidade, sendo não compreendido pelos que estão fora dela. As ciências humanas e sociais, com exclusão do Direito que possui linguagem de especialidade bem delineada e amplamente reconhecida e pesquisada, se vale de termos, que muitas vezes se confundem com palavras do senso comum, para expressar suas teorias e pesquisas.

As ciências sociais aplicadas, campo em que $\mathrm{Cl}$ se insere, têm como característica a adoção de teorias de outras ciências para concretizar seus objetivos. Junto à adoção de teorias ocorre, necessariamente, a adoção dos termos correspondentes aos conceitos adotados. É preciso expressar essa adoção em pesquisas e estudos e os termos são o meio próprio para isso. A questão surgida com essa importação é de que a $\mathrm{Cl}$, enquanto uma ciência importadora, pode receber tantos conceitos de outras áreas ao passo de não conseguir delinear um núcleo básico de conceitos próprios. Questão reforçada por Smit e Tálamo ao afirmarem que "os pioneiros as $\mathrm{Cl}$ consideravam o maior perigo a ser enfrentado pela área recém-criada residia na falta de um corpo conceitual próprio" (2007, p.38).

Compartilhamos desse apontamento ao constatar que se nos artigos científicos da área $62 \%$ das ocorrências de palavras-chave não possuem traços ou características que as configuram como termo, o conceito pode ter sido apenas importado para a área, sem devida reflexão e adequação ao contexto da práxis da Ciência da Informação. 


\section{CONCLUSÕES}

Analisar a linguagem de especialidade da Ciência da Informação com base na aplicação dos conceitos em artigos de periódicos científicos da área trata-se do objetivo principal de nossa pesquisa. Optarmos por uma metodologia exploratória, ao tentar uma nova abordagem para a pesquisa da linguagem de especialidade da Ciência da Informação em face da carência de estudos sobre o tema pela perspectiva da Terminologia. Os trabalhos produzidos por outros autores nos impulsionaram na tentativa de encontrar novos caminhos para esse estudo e que, de alguma forma, pudéssemos enxergar mais nitidamente os contornos dessa linguagem.

Com nossa pesquisa pudemos constatar que algumas proposições que tínhamos no início do trabalho se confirmaram e outras não.

Uma de nossas proposições está relacionada à pouca delimitação de sua terminologia, que pode ocorrer, entre outros motivos, pela carência de estudos e pesquisa na área, pelo uso de termos de outras áreas apenas para aproximá-la dos temas que estão em evidência, pelo baixo reconhecimento entre outras ciências, pelos poucos investimentos - tanto das agências financiadoras, como das universidades - em pesquisa sobre sua linguagem de especialidade, pelo baixo interesse dos pesquisadores sobre o tema, pelo não entendimento de que ter uma linguagem de especialidade é fator de afirmação de um campo científico, pela restrição de suas ações a ambientes de bibliotecas e centros de documentação (cenário em mudança com a atuação desses profissionais em equipes de organização da informação em ambientes virtuais e outras iniciativas possibilitadas pela novas mídias), pela postura do profissional que, em muitos casos, sente-se inferior aos especialistas de outras áreas, tais como Medicina, Engenharia, Direito, e, também, por se utilizar da linguagem de especialidade desses profissionais para execução do seu trabalho ou até pela mera importação, sem reflexão, de termos e conceitos de outras áreas na produção de textos.

A quantidade de palavras-chave que não possuem traços ou características que as configuram como termo equivale a $15,4 \%$ do total de 
palavras-chaves, sem esquecer que $49,4 \%$ das ocorrências das palavras-chave que possuem traços ou características que as configuram como termo, não continham de fato qualquer menção, traços ou características que as configuram como termo. Como nossa pesquisa é exploratória, não possuímos parâmetros para avaliar se esse percentual é ou não adequado para avaliar a linguagem de especialidade de uma área, porém entendemos que para ocorra a efetiva comunicação entre participantes de uma comunidade de prática, que é permeada por termos e conceitos, estes devem ser compartilhados e entendidos plenamente por seus falantes. Se há omissão de conceitos, essa comunicação, e também a compreensão do conteúdo do texto, pode ser prejudicada.

Ao escolhermos trabalhar com artigos científicos, partimos da premissa de que esse tipo de texto é uma forma de comunicação científica, e o periódico cientifico se constituiu como um canal formal de disseminação da informação acadêmica, científica e tecnológica, sendo o artigo científico a forma definitiva de publicação dos resultados. A efetiva divulgação dos resultados em canais com penetração na comunidade científica proporciona ao pesquisador um retorno de imagem e reconhecimento do seu trabalho, pois seus resultados podem servir de fonte de informação para outras pesquisas, tornando-se referência em sua área de atuação.

Essa premissa se consolida diante da análise das seções Foco e Escopo e dos objetivos das publicações analisadas. Ambas têm como objetivo a divulgação de resultados de estudos e pesquisas, constituindo-se como veículos de disseminação do conhecimento científico e de interlocução e que representem contribuição para 0 desenvolvimento de novos conhecimentos entre pesquisadores, docentes, discentes e profissionais em Ciência da Informação, Biblioteconomia e áreas afins.

Ainda sobre a questão dos artigos científicos como uma forma de comunicação científica, tínhamos expectativa que todas as palavra-chaves selecionadas teriam, ao menos, um traço ou característica que pudéssemos atribuí-la como conceito, o que não se concretizou. Tal expectativa decorre de nosso primeiro objetivo específico, a discussão acerca da aplicação dos conceitos 
e da apresentação ou não de sua definição, e do possível consenso implícito na não apresentação do conceito nos artigos;

Propomos algumas causas para a ausência de traços ou características que as configuram como termo, com base em nossa experiência e análise dos dados, mas, sem pretensão de levantá-las em sua totalidade, de modo que como são atribuídas pelo autor sem nenhuma regulamentação por parte dos periódicos onde foram divulgadas, as causas podem ser outras.

A não definição ou conceituação dos termos utilizados pelos autores em seus textos pode dificultar não só a comunicação entre os pares, a compreensão do documento pelos leitores, mas também não fornece subsídios consistentes para que os pesquisadores da linguagem de especialidade da área tenham material adequado para seus estudos. Se formos ao extremo dessa prática as pesquisas científicas nesse segmento podem até retratar algo que não condiz com a realidade. Essa não é nossa percepção, constatamos que a pouca apresentação de conceitos pode estar relacionada a um problema de identidade do campo da Ciência da Informação, todavia essa problemática não pode ser desconsiderada.

Pelo que constatamos junto às definições de cada palavra-chave no Dicionário de Biblioteconomia e Arquivologia, de maneira geral, as mesmas estão sendo usadas pelos autores dos artigos dentro do contexto de suas definições. Mesmo suas características não estando explícitas no texto, o conceito foi internalizado pelo autor que atribuiu a palavra-chave, inclusive no caso de serem expressas no Dicionário mais de uma acepção. Resta ao leitor também possuir essa noção ou recorrer a obras de referência, como a usada por nós nesse estudo, para auxiliá-lo quando ocorrerem dúvidas sobre o significado.

Podemos inferir que as palavras-chave que não possuem traços ou características que as configuram como termo estão de alguma forma relacionadas à proposta dos inter-conceitos de Wersig? Não iríamos tão longe em relação as palavras-chave como Sistema de informação com duas acepções referentes a campos distintos e Cientometria, que em artigo recente no jornal Folha de São 
Paulo $^{33}$ sobre o ritmo acelerado das pesquisas científicas, foi citado juntamente com a definição "medição da produtividade científica" entre parênteses. Em se tratando das palavras-chave Tecnologia da informação e comunicação, Produtividade de autores, Produção científica e Publicação eletrônica, arriscamos a dizer que essas, em relação aos resultados dessa pesquisa, podem ser consideradas inter-conceitos, o que não garante que a totalidade dos sujeitos que as empregam tenha clareza de seu conceito.

Observamos que as palavras-chave que não possuem traços ou características que as configuram como termo estão sempre acompanhadas de palavras-chave com descrição do conceito, com até mais de uma associação. Fato esse que reforça a proposição de que o conceito não descrito já deve ser de conhecimento do autor ou o autor não o considera tão necessário para o entendimento de sua obra. Mas se o autor não o considera tão necessário para o entendimento de sua obra, supomos que o utilize também como identificador ou localizador que será recorrido pelo usuário no momento da busca. Se um artigo é localizado com maior precisão em relação à necessidade do usuário, o mesmo terá uma maior probabilidade de ser referenciado, atendendo assim a uma das aspirações do autor.

Considerando que as linguagens de especialidades

- São "antes de tudo um meio de expressão de conteúdo temático" (MACIEL, 2010, p.10);

- Não se limitam a interação formal entre especialistas, mas também "é utilizada por interlocutores de diferentes hierarquias e graus de especialização em diferentes níveis de formalidade" (MACIEL, 2010, p.16);

- Possibilitam "a configuração, expressão e comunicação do conhecimento visa contribuir para adequada transmissão do conhecimento..." (MACIEL, 2010, p.14-15);

\footnotetext{
${ }^{33}$ RIGHETTI, Sabine. 'Slow Science' prega pesquisa científica em ritmo desacelerado. Folha de S.Paulo, caderno Ciência, 08 de agosto de 2011. Disponível em: < http://www1.folha.uol.com.br/ciencia/956065-slow-science-prega-pesquisa-cientifica-em-ritmodesacelerado.shtml> Acesso em 08 ago. 2011
} 
- Refletem "os propósitos da comunicação", entretanto compartilham da "função denominativa básica da linguagem especializada" e que se "somam a outras funções tais como a informativa, a argumentativa, a descritiva e a prescritiva", sem nenhuma exclusividade, porém se adequa aos propósitos de cada área do conhecimento onde em cada caso um função exerce predominância sobre outras (MACIEL, 2010, p.20);

questionamos se a não conceituação ou definição do termo utilizado como representante do conteúdo do documento reflete um baixa especialização do discurso da Ciência da Informação.

Essa é apenas uma característica em relação à especialização do texto, como é proposto por Maciel ao afirmar que "a especialização resulta de um complexo contexto, no qual não só o aspecto do conteúdo é importante, isto é, não é o significado léxico o único e exclusivo fator que Ihe confere caráter específico" (MACIEL, 2010, p.19) mas também "da combinação de dois critérios: critério temático e critério pragmático” (MACIEL, 2010, p.21).

Ao realizar os levantamentos teóricos para essa dissertação mostrou-se necessário um maior conhecimento no campo da Linguística, devido não ser a nossa formação primordial, e nessa incursão nos deparamos com as teorias da Terminologia Textual e da Linguística do Texto especializado. Tais estudos mostraram-se úteis para as pesquisas da linguagem de especialidade da Ciência da Informação ao passo que, dentre as tantas aplicações e vertentes, têm foco no conceito de especialização do texto, seu grau de especificidade, avaliando a extensão e essência do conhecimento, porém não analisam "os elementos distintivos que caracterizam o texto como expressão do conhecimento de uma área particular" (MACIEL, 2010, p.23).

Em relação ao segundo objetivo específico que seria a proposição de uma metodologia para a constituição de uma lista de termos para auxiliar na pesquisa da linguagem de especialidade em Ciência da Informação, podemos concluir que o trabalho das palavras-chave evidenciou a diversidade de disciplinas em estudo e de temas pesquisados pela área. Entretanto, pelas questões referentes à problemática da atribuição dessas palavras-chaves acreditamos que essa abordagem não seria plenamente adequada como metodologia de análise da 
linguagem de especialidade em Ciência da Informação. Propomos que ela seja uma parte da metodologia, que deve também contar com outros tipos de fontes para seleção do corpus de coleta, enriquecendo ainda mais a análise.

Quanto ao nosso objetivo geral que seria analisar a linguagem de especialidade da Ciência da Informação e, considerando genericamente que linguagem de especialidade compreende a terminologia e demais meios linguísticos de um campo científico, uma área, um domínio ou um subdomínio que objetiva uma comunicação eficaz e sem ambiguidades entre os sujeitos que a compartilham, concluímos que a Ciência da Informação possui uma linguagem de especialidade, porém não podemos aferir um grau a essa especialização. Existem estudos sobre grau de especialização do texto científico, como a proposta de Guiomar Ciapuscio em seu livro Textos especializados y terminologia ${ }^{34}$, que apresenta uma metodologia para a gradação da especificidade de um texto, porém, a metodologia proposta pela autora não é compatível com nosso universo de dados.

Por se tratar de um estudo exploratório, um primeiro olhar sob o tema linguagem de especialidade da $\mathrm{Cl}$ pelo aspecto da conceituação ou definição de palavras-chaves dentro do texto de artigos científicos, sem nenhuma intenção de exaustividade e sim de abertura de novas possibilidades, constatamos que a linguagem de especialidade encontra-se difusa, sem definição clara do domínio ao qual os termos (nesse caso oriundos das palavras-chaves) se referem. Entendemos que ao usar uma obra de referência que não se intitula diretamente referente o domínio da Ciência da Informação devemos relativizar nossa conclusão sobre a linguagem de especialidade da $\mathrm{Cl}$, no sentido de que as definições dos conceitos discutidos se referem ao domínio da Biblioteconomia a Arquivologia, porém era nossa mais consistente escolha.

Com base nessa amostra, demonstramos que os pesquisadores e profissionais da área deveriam produzir textos de caráter científico com uma maior dedicação à explicitação do campo científico, das teorias e conceitos, não restringindo-se apenas à adoção de palavras-chaves chamativas, porém vazias de

\footnotetext{
${ }^{34}$ CIAPUSCIO, G. Textos especializados y terminologia. Barcelona: Instituto Universitario de Lingüística Aplicada, 2003.
} 
significado. Se a produção técnico-científica em Ciência da Informação concentrasse mais conceitos e definições, a mesma poderia ser vista como uma área do conhecimento mais sólida, conferindo-lhe maior destaque $\mathrm{e}$ reconhecimento? Isoladamente, não será somente essa mudança de postura o fator que a conferirá a identidade e reconhecimento que a Ciência da Informação almeja, mas acreditamos que seja importante parte desse processo.

Devemos primar por uma terminologia o mais próxima das necessidades de comunicação da Ciência da Informação e que reflita seus processos, teorias e práticas. Entendemos que em muitos casos os termos e até suas definições, serão de outras áreas, mas nesses empréstimos deve ficar claro o que o conceito empregado representa para $\mathrm{Cl}$, qual sua contribuição e seus limites, que podem ou não convergir para a definição do conceito em sua área de origem. Precisamos delimitar qual é o domínio da Ciência da Informação e os conceitos que a fazem ser Ciência da Informação e não Biblioteconomia, Documentação, Tecnologia da Informação. Porém, para que essa delimitação conceitual seja feita, é necessário que estas questões estejam resolvidas pelo campo científico, pois elas serão explicitadas por meio do discurso técnico-científico. Acreditamos que nesse momento a Ciência da Informação está em busca desse precioso referencial e, se os estudos e pesquisas estiverem atentos à questão da linguagem de especialidade, poderemos ter horizontes promissores.

O processo de construção do conhecimento científico se apoia no levantamento do estado da arte de qualquer ciência para, não só entender o caminho que se percorreu para chegar no estágio atual, mas também continuar. Continuar evitando os erros já cometidos, seguindo caminhos ainda não desbravados, otimizando o tempo e os recursos dos pesquisadores e das instituições. Esperamos, assim, que nossa pesquisa contribua para a construção do conhecimento em Ciência da Informação, ao indicar que sua linguagem de especialidade carece de estudos, para reforçarmos seu caráter científico, e práticas, para que possamos reconhecer e afirmar sua identidade. 


\section{REFERÊNCIAS BIBLIOGRÁFICAS}

ABBOTT, Andrew. The system of professions: an essay on the division of expert labor. Chicago: The University of Chicago Press. 1988.

AQUINO, Miriam de Albuquerque. (org.). O campo da ciência da informação: gênese, conexões e especificidades. João Pessoa: UFPB, 2002.

ARRUDA, Susana Margaret de; CHAGAS, Joseane. Glossário de

Biblioteconomia e Ciências Afins. Florianópolis: Cidade Futura, 2002.

AUGÉ, Marc. Não-lugares: introdução a uma antropologia da supermodernidade. Campinas, SP : Papirus, 1994.

BARBOSA, M.A. Lexicologia, lexicografia, terminologia, terminografia: identidade científica, objeto, métodos, campos de atuação. In: II Simpósio Latino-

Americano de Terminologia. I Encontro Brasileiro de Terminologia TécnicoCientífica. Anais. Brasília: União Latina, CNPq, IBICT, 1990. Disponível em: <http://www.riterm.net/actes/2simposio/barbosa2.htm> Acesso em: 18 abr. 2010

BARBOSA, M.A. Sistema conceptual e sistema terminológico. TradTerm: Revista do Centro Interdepartamental de Tradução e Terminologia, n.7, 2001, p. 71-94.

BARRETO, Aldo. A. . O tempo e o espaço da Ciência da Informação.

Transinformação, Campinas, v. 14, n. 1, 2002, p. 17-24.

BARROS, Lídia Almeida. Curso básico de terminologia. São Paulo: EDUSP, 2004.

BAUMAN, Zygmunt. O Mal-Estar da Pós-Modernidade. Rio de Janeiro: Jorge Zahar, 1998.

BAUMAN, Zygmunt. Modernidade e Ambivalência. Rio de Janeiro: Jorge Zahar, 1999.

BAUMAN, Zygmunt. Modernidade Líquida. Rio de Janeiro: Jorge Zahar, 2001.

BAUMAN, Zygmunt. Amor Líquido: sobre a fragilidade dos laços humanos. Rio de Janeiro: Jorge Zahar, 2004.

BAUMAN, Zygmunt. Vida Líquida. Rio de Janeiro: Jorge Zahar Editor, 2006.

BENTES PINTO, V.; CAVALCANTE, L. E.; SILVA NETO, C. (Org). Ciência da Informação: abordagens transdisciplinares, gêneses e aplicações. Fortaleza: Ed. UFC, 2007. 
BENVENISTE, Émile. Gênese do termo "scientifique". In: lingüística geral, II. Campinas: Pontes, 1989, p. 252-258. Problemas de

BERMAN, Marshall. Tudo que é sólido desmancha no ar: a aventura da modernidade. São Paulo: Companhia das Letras, 1998.

BIOJONE, M.R. Forma e função dos periódicos científicos na comunicação da ciência São Paulo: Educ / Fapesp, 2003.

BORKO, H. Information science: what is it? American Documentation, v.19, n.1, p.3-5, jan. 1968.

BUCKLAND, M. Information as thing. Journal of the American Society for Information Science, v.45, n.5, p. 351-360, 1991.

BUCKLAND, M. Five Grand Challenges for Library Research. Library Trends, v. 51, n. 4, p. 675-686, 2003. Disponível em: $<$ http://people.ischool.berkeley.edu/ buckland/trends03.pdf>. Acesso em: 12 jul. 2009

BURKE, Peter. Uma história social do conhecimento: de Gutenberg a Diderot. Rio de Janeiro: Zahar, 2003.

BUSH, W. As We May Think. The Atlantic Monthly, v.176, n.1, jul. 1945.

Disponível em: <http://www.theatlantic.com/doc/194507/bush> Acesso em: 12 jul. 2009.

CABRÉ, Maria Teresa. La terminología hoy: concepciones, tendencias y aplicaciones. Ciência da Informação, Brasília, v.24, n. 3, set./dez. 1995. Disponível em:

$<$ http://www.ibict.br/cionline/viewarticle.php?id=530\&layout=abstract $>$. Acesso em: 12 jul 2008.

CABRÉ, Maria Teresa. Terminología y documentación. In: . La terminologia: representación y comunicacion: elementos para una teoría de base comunicativa y otros artículos. Barcelona: IULA/Universitat Pompeu Fabra. 1999

CAPURRO, Rafael. Epistemologia e Ciência da informação. In: V ENCONTRO NACIONAL DE PESQUISA EM CIÊNCIA DA INFORMAÇÃO, 5., Belo Horizonte, 2003. Disponível em: <http://www.capurro.de/enancib_p.htm> Acesso em: 16 jul. 2009.

CAPURRO, R., HJØRLAND, B. O conceito de informação. Perspectivas em Ciência da Informação, Belo Horizonte, v.12, n.1, 2007. Disponível em: http://www.eci.ufmg.br/pcionline/ Acesso em: 20 ago. 2009

CIAPUSCIO, Guiomar. Textos especializados y terminologia. Barcelona: Instituto Universitario de Lingüística Aplicada, 2003. 
CIÊNCIA DA INFORMAÇÃO. Rio de Janeiro: IBICT, 2005-2009.

COORDENAÇÃO DE APERFEIÇOAMENTO DE PESSOAL DE NÍVEL SUPERIOR (CAPES). Qualis Periódicos. Disponível em: <http://www.capes.gov.br/avaliacao/qualis> Acesso em: 01 jul. 2010.

CUNHA, Murilo Bastos da; CAVALCANTI, Cordélia Robalinho de Oliveira.

Dicionário de Biblioteconomia e Arquivologia. Brasília: Briquet de Lemos, 2008.

DIAS, Cláudia Augusto. Terminologia: conceitos e aplicações. Ci. Inf., Brasília, vol.29, n.1, p.90-92, jan./abr. 2000.

FONSECA JÚNIOR, Wilson Corrêa. Análise de conteúdo. In: DUARTE, Jorge; BARROS, Antonio. Métodos e técnicas de pesquisa em comunicação. São Paulo: Atlas, 2010, p.280-304.

GALVÃO, Maria Cristiane Barbosa; BORGES, Paulo César Rodrigues. Ciência da informação: ciência recursiva no contexto da sociedade da informação. Ci. Inf., Brasília, vol.29, n.3, p.40-49, set./dez. 2000.

GIDDENS, Anthony. As conseqüências da modernidade. São Paulo: Editora UNESP, 1991.

GIL, Antônio Carlos. Métodos e Técnicas de Pesquisa Social. São Paulo, Ed. Atlas, 1999.

GONZÁLEZ de GÓMEZ, Maria Nélida. Escopo e abrangência da Ciência da Informação e a pós-graduação na área: anotações para uma reflexão.

Transinformação, Campinas, v.15, n. 1, p. 31-43, 2003.

INFORMAÇÃO \& SOCIEDADE: ESTUDOS. João Pessoa: UFPB - Universidade Federal da Paraíba,, 2005-2009.

INGWERSEN,P. Conceptions of informations science. In: VAKKARI, P.; CRONIN, $B$. Conceptions of library and information science: historical, empirical and theoretical perspetives. London: Taylor Graham, 1992. p. 299-312.

ISO 704 (2000). Terminology work - principles and methods. 2nd ed. Genève: International Standard Organization, 2000.

ISO 1087-1(2000). Terminology work - Vocabulary, Part 1: theory and application/Travaux terminologiques - Vocabulaire - Partie 1: théorie and application. Genève: International Standard Organization, 2000.

ISO 2788/BSI(1986) Guide to establishment and development of monolingual thesauri. London: BSI, 1986.

JAMESON, Fredric. Pós Modernismo: A lógica cultural do capitalismo tardio. São Paulo: Editora àtica, 1996. 
KOBASHI, N. Y.; SMIT, J. W.; TÁLAMO, M. F. G. M.. A função da terminologia na construção do objeto da ciência da informação. Datagramazero - Revista de Ciência da Informação, Rio de Janeiro, v.2, n. 2, abr/2001. Disponível em: < http://www.dgz.org.br/abr01/F_I_aut.htm>. Acesso em: 08 jul 2008.

KOBASHI, N. Y.; TÁLAMO, M. F. G. M. . Informaçao: fenômeno e objeto de estudo da sociedade contemporânea. Transinformação, Campinas, v. 15, 2003, p. 7-22. Disponível em: <http://revistas.puc-

campinas.edu.br/transinfo/viewissue.php?id=5> Acesso em 30 nov. 2009.

KRIEGER, Maria da Graça. Terminologia revisitada. DELTA, São Paulo, v.16, n.2, 2000, p. 209-228 . Disponível em:

<http://www.scielo.br/scielo.php?script=sci_arttext\&pid=S0102-

$44502000000200001 \&$ lng=en\&nrm=iso $>$. Acesso em: 20 jun. 2011

KRIEGER, Maria da Graça. O termo: questionamentos e configurações.

TradTerm: revista do Centro Interdepartamental de Tradução e Terminologia FFLCH/USP, São Paulo, v. 1, n. 7, 2001, p111-140.

KRIEGER, M. G. ; BEVILACQUA, C. R. . A pesquisa terminológica no Brasil: uma contribuição para a consolidação da área. Debate Terminológico, v. 1, p. 1-11, 2005.

LARA, M.L.G. Linguagens Documentárias, instrumento de mediação e comunicação. Revista Brasileira de Biblioteconomia e Documentação, São Paulo, v. 26, n. 1/2, p.72-80, jan./jun. 1993.

LARA, M.L.G. Representação e linguagens documentárias: bases teóricometodológicas. São Paulo, 1999, Tese (Doutorado): Escola de Comunicação e Artes, Universidade de São Paulo.

LARA, M.L.G. Elementos de terminologia: Apostila para uso didático. São Paulo: ECA/USP, 2005.

LARA, M. L. G. Informação, informatividade e Lingüística Documentária: alguns paralelos com as reflexões de Hjørland e Capurro. DataGramaZero - Revista de Ciência da Informação. Rio de Janeiro, v.9, n.6, dez. 2008. Disponível em:

Acesso em: 15 jul. 2009.

LARA, M.L.G. \& TÁLAMO, M.F.G.M. Uma experiência na interface Linguística Documentária e Terminologia. DataGramaZero - Revista de Ciência da Informação. Rio de Janeiro, v.8, n. 5, out. 2007. Disponível em: <http://www.datagramazero.org.br/out07/Art_01.htm> Acesso em 03 dez. 2009.

LE COADIC, Yves-François. A Ciência da Informação. 2 ed. Brasília: Briquet de Lemos, 2004.

LE GOFF, Jaques. História e memória. 5ed. Campinas: Editora UNICAMP, 2003 
LIMA, V.M.A. A terminologia e a função comunicativa das linguagens documentárias.In: X Simpósio Iberamericano de Terminologia. Montevidéu, 2006.

LIPOVETSKY, Gilles. A era do vazio: ensaio sobre o individualismo. Barueri: Manole, 2006.

MACIEL, Anna Maria Becker. Linguagens especializadas e terminologia: o passado projetando o futuro. In: PERNA, Cristina Lopes; DELGADO, Heloísa Koch; FINATTO, Maria José (org). Linguagens especializadas em corpora: modos de dizer e interfaces de pesquisa. Porto Alegre: EDIPUCRS, 2010, p. 0628.

MEDEIROS, Marisa Bräscher Basílio. Terminologia brasileira em ciência da informação: uma análise. Ci. Inf., Brasília, v.15, n.2, jul./dez. 1986, p. 135-142.

MURGUIA, Eduardo Ismael. Discursividade da Ciência da Informação e sua institucionalização na Biblioteconomia e a arquivologia: um estudo comparado. In: ENCONTRO NACIONAL DE PESQUISA EM CIÊNCIA DA INFORMAÇÃO (ENANCIB), 11, 2010, Rio de Janeiro, RJ. Anais do XI Encontro Nacional de Pesquisa em Ciência da Informação. Rio de Janeiro: 2010.

NAKAYAMA, Haruka. Terminologia aplicada à biblioteca de escola de língua. In: VIANNA, Márcia Milton; CAMPELLO, Bernadete; MOURA, Victor Hugo Vieira. Biblioteca escolar: espaço de ação pedagógica. Belo Horizonte: EB/UFMG, 1999. p. 106-110. Seminário promovido pela Escola de Biblioteconomia da Universidade Federal de Minas Gerais e Associação dos Bibliotecários de Minas Gerais, 1998, Belo Horizonte.

PERSPECTIVAS EM CIÊNCIA DA INFORMAÇÃO. Belo Horizonte: UFMGUniversidade Federal de Minas Gerais, 2005-2009.

PESTRE, Dominique. Por uma nova história social e cultural das ciências: novas definições, novos objetos, novas abordagens, Cadernos IG-Unicamp, Campinas, v. 6, n. 1, p. 3-56, 1996.

PINHEIRO, Lena Vânia Ribeiro. Processo evolutivo e tendências contemporâneas da Ciência da Informação. Informação e Sociedade, João Pessoa, v. 15, n. 1, 2005.

PINHEIRO, L. V. R. ; LOUREIRO, J. M. M. . Traçados e limites da Ciência da Informação. Ciência da Informação, Brasília, v. 24, n. 1, p. 42-53, 1995.

POMBO, Olga. Interdisciplinaridade: conceito, problemas e perspectivas. LEVY,Teresa; GUIMARÃES, Henrique; POMBO, Olga. A interdisciplinaridade: reflexão e experiência. $2^{\mathrm{a}}$ edição revista e aumentada. Lisboa: ed. Texto, 1994. p814. Disponível em: $<$ http://www.educ.fc.ul.pt/docentes/opombo/mathesis/interdisciplinaridade.pdf> Acesso em 05 maio 2010. 
OLIVEIRA, A.M.P.; IZQUERDO, A.N. (Orgs.). As ciências do léxico. Campo Grande: UFMS, 1998.

ORTEGA, Cristina Dotta. Relações históricas entre Biblioteconomia, Documentação e Ciência da Informação. Datagramazero: Revista de Ciência da Informação, Rio de Janeiro, v. 5, n. 5, out. 2004

RAYWARD, W.B. The origins of information science and the International Institute of Bibliography/International Federation for Information and Documentation (FID). Journal of the American Society for Information Science, v.48, n.4, p.289-300, 1997.

REICHMANN, Tinka . Marcas culturais nas linguagens de especialidade.

Lusorama, v. 77-78, p. 103-122, 2009.

RENDÓN ROJAS, M. A. La ciencia de la información en el contexto de las ciencias sociales y humanas. Ontología, epistemología, metodología e interdisciplina. Datagramazero - Revista de Ciência da Informação, Rio de Janeiro, v. 9, n. 4, ago. 2008. Disponível em: <http://www.dgz.org.br/ago08/F_I_art.htm>. Acesso em: 29 set 2008.

SAGER, J.C. Prólogo: la terminología: puente entre varios mundos. In: CABRÉ, M.T. La terminología: teoria, metodologia, aplicaciones. Barcelona: Antártida/Empúries, 1993. p. 11-17.

SANTOS, Jair Ferreira.O que é pós-moderno. São Paulo: Editora Brasiliense, 1987.

SANTOS, Boaventura Sousa. Um discurso sobre as ciências. Porto: Afrontamento, 1987.

SANTOS, Boaventura Sousa. Introdução a uma ciência pós-moderna. 4 ed. Rio de Janeiro: Graal, 1989.

SARACEVIC, Tefko. Interdisciplinary nature of information science. Ciência da Informação, Brasília v. 24, n.1, 1995. Disponível em:

$<$ http://revista.ibict.br/index.php/ciinf/article/view/530/482>. Acesso em: 17 jul. 2009.

SARACEVIC, Tefko. Ciência da Informação: origem, evolução e relações.

Perspectivas em Ciência da Informação, Belo Horizonte, v. 1, n. 1, p. 41-62, jan./jun. 1996.

SARACEVIC, Tefko. Information Science. Journal of The American Society for Information Science, v,50, n.12: p.1051-1063, 1999. Disponível em: <http://comminfo.rutgers.edu/ tefko/JASIS1999.pdf> Acesso em 17 jul. 2009

SILVEIRA, Murilo Artur Araújo da; BAZI, Rogério Eduardo Rodrigues. Rede de Textos Científicos na Ciência da Informação: análise cienciométrica da 
institucionalização de um campo científico. DataGramaZero - Revista de Ciência da Informação, Rio de Janeiro, v.9, n.3. jun/2008. Disponível em <http://www.dgz.org.br/jun08/Art_01.htm> . Acesso em 10 fev 2008.

SMIT, J. W. ; TÁLAMO, M. F. G. M. Ciência da Informação: uma ciência moderna ou pós-moderna? In: LARA, M.L.L; FUJINO, A.; NORONHA, D.P. Informação e contemporaneidade: perspectivas. Recife : Néctar, 2007. p. 27-45

SMIT, J. W.; TÁLAMO, M. F. G. M. ; KOBASHI, N. Y . A determinação do campo científico da Ciência da Informação: uma abordagem terminológica.

Datagramazero - Revista de Ciência da Informação, Rio de Janeiro, v. 5, n. 1, fev. 2004. Disponível em: < http://www.dgz.org.br/fev04/F_I_art.htm>. Acesso em: 02 set 2008.

SOUSA, Paulo Tarso. Teoria da jurisdição do capital social: abordagens para o estudo do profissional da informação. Informação \& Sociedade: estudos, João Pessoa, v.17, n.2, p.41-50, maio/ago. 2007.

SOUZA, Edivanio Duarte. Dimensões teórico-metodológicas da Ciência da Informação: dos desafios à consolidação epistemológica. In: ENCONTRO NACIONAL DE PESQUISA EM CIÊNCIA DA INFORMAÇÃO (ENANCIB), 09, 2008, São Paulo, SP. Anais do IX Encontro Nacional de Pesquisa em Ciência da Informação. São Paulo: 2008.

SOUZA, Gisele Pereira de. O conceito contemporâneo de Ciência da Informação ante a terminologia consolidada da área. São Paulo, 2006. 59p. Monografia (Trabalho de Conclusão de Curso) - Departamento de Biblioteconomia e Documentação, Escola de Comunicações e Artes, Universidade de São Paulo.

STUMPF, Ida Regina. Pesquisa bibliográfica. In: DUARTE, Jorge; BARROS, Antonio. Métodos e técnicas de pesquisa em comunicação. São Paulo: Atlas, 2010, p. 51-61.

TÁLAMO, M. F. G. M. Terminologia e documentação. TradTerm: revista do Centro Interdepartamental de Tradução e Terminologia FFLCH/USP, São Paulo, v. 1, n. 7,2001 , p. 141-151.

TOUTAIN, L. M. B. B. (org). Para entender a Ciência da Informação. Salvador, EDUFBA, 2007.

VÀLIO, Else Benetti Marques; OLIVEIRA, Vanda de Fátima Fulgêncio de. Terminologia da ciência da informação: abordagem da análise do discurso. Perspect. Cienc. Inf., Belo Horizonte, v. 8, n. 2, jul./dez. 2003, p. 114-133.

VAN DER LAAN, Regina Helena; ALVORCEM, Rochelle Martins. A terminologia expressa no discurso dos especialistas da área de Ciência da Informação: um estudo de caso. Revista Brasileira de Biblioteconomia e Documentação, Nova Série, São Paulo, v.3, n.2, jul./dez. 2007, p.107-115. 
WERSIG, G. Information science: the study of postmodern knowledge usage.

Information Processing \& Management, v.29, n.2, 1993, p. 229-239.

WHITLEY, R. Social process of science development. London; Boston:

Routlege \& Kegan, 1974. 
APÊNDICE I - MODELO DE FICHA DE COLETA DE TERMINOLÓGICA

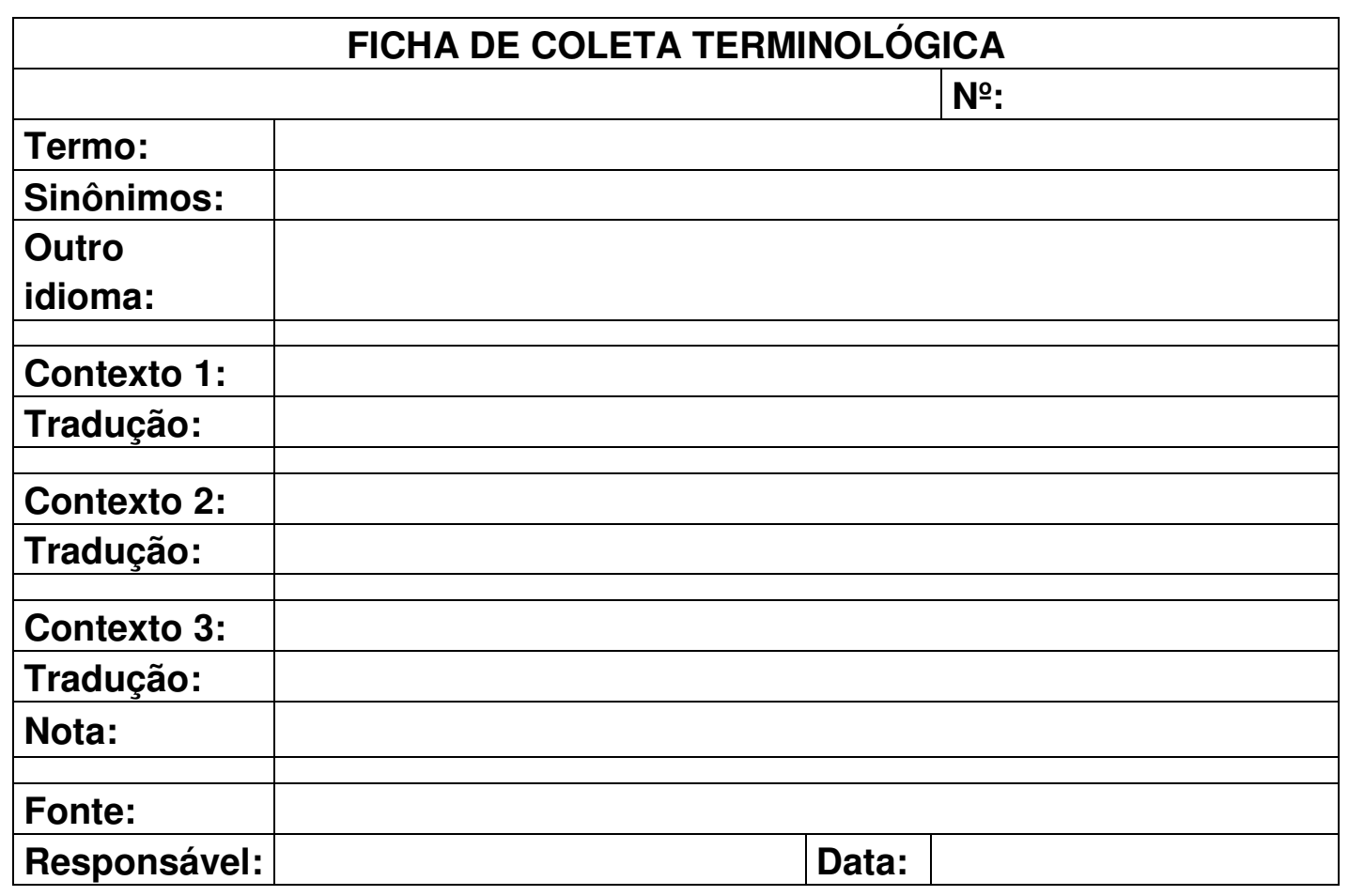




\section{APÊNDICE II - LISTA FINAL DE PALAVRAS-CHAVE COLETADAS}

\begin{tabular}{|c|c|c|c|}
\hline Palavra-chave & Ocorrência & Palavra-chave & Ocorrência \\
\hline Ciência da Informação & 41 & Epistemologia & 1 \\
\hline Gestão do conhecimento & 30 & Epistemologia social & 1 \\
\hline Comunicação científica & 21 & Eprints & 1 \\
\hline Informação & 20 & Equipe de inteligência competitiva & 1 \\
\hline Gestão da informação & 19 & Ergonomia & 1 \\
\hline Bibliometria & 18 & $\begin{array}{l}\text { Especificidades das pequenas } \\
\text { empresas }\end{array}$ & 1 \\
\hline Competência informacional & 11 & Estado & 1 \\
\hline $\begin{array}{l}\text { Tecnologia da informação e } \\
\text { comunicação }\end{array}$ & 11 & Estatística & 1 \\
\hline Biblioteca digital & 10 & Estatística em bibliotecas & 1 \\
\hline Internet & 10 & Estrada & 1 \\
\hline Profissional da informação & 10 & $\begin{array}{l}\text { Estratégia em gestão do } \\
\text { conhecimento }\end{array}$ & 1 \\
\hline Sociedade da informação & 10 & Estratégias & 1 \\
\hline Biblioteca & 8 & Estratégias metacognitivas & 1 \\
\hline Bibliotecário & 8 & Estrutura de classificação & 1 \\
\hline Conhecimento & 8 & Estrutura organizacional em rede & 1 \\
\hline Fonte de informação & 8 & Estruturas organizacionais & 1 \\
\hline Informetria & 8 & Estudo de casos múltiplos & 1 \\
\hline Aprendizagem organizacional & 7 & Estudos de uso & 1 \\
\hline Biblioteca escolar & 7 & $\begin{array}{l}\text { Estudos em Ciência da } \\
\text { Informação }\end{array}$ & 1 \\
\hline Cientometria & 7 & Estudos quantitativos & 1 \\
\hline Inclusão digital & 7 & Ética da informação & 1 \\
\hline Inteligência competitiva & 7 & Ética profissional & 1 \\
\hline Arquivos abertos & 6 & Avaliação & 1 \\
\hline Produção científica & 6 & Eventos científicos & 1 \\
\hline Redes sociais & 6 & Eventos técnico-científico & 1 \\
\hline Sistema de informação & 6 & Exclusão digital & 1 \\
\hline Acesso aberto & 5 & Exclusão social no Brasil & 1 \\
\hline Biblioteca universitária & 5 & Facilidade de uso & 1 \\
\hline Biblioteconomia & 5 & Fator de impacto & 1 \\
\hline Ciberespaço & 5 & Fator de leitura & 1 \\
\hline Indicadores & 5 & Fator humano nas organizações & 1 \\
\hline Informação científica & 5 & Fazer profissional & 1 \\
\hline Interdisciplinaridade & 5 & Ferramenta de texto & 1 \\
\hline Ontologia & 5 & Ferramentas de colaboração & 1 \\
\hline Organização do conhecimento & 5 & Ferramentas de gestão & 1 \\
\hline Periódico científico & 5 & Filosofia & 1 \\
\hline Produtividade de autores & 5 & Filosofia aberta & 1 \\
\hline Publicação eletrônica & 5 & Filosofia da Informação & 1 \\
\hline Qualidade da informação & 5 & Filosofia da multiplicidade & 1 \\
\hline Acesso livre & 4 & Fluxo de informação & 1 \\
\hline Análise de citação & 4 & Fluxo e uso de informação & 1 \\
\hline Aprendizagem & 4 & Formação continuada & 1 \\
\hline
\end{tabular}




\begin{tabular}{|c|c|c|c|}
\hline Palavra-chave & Ocorrência & Palavra-chave & Ocorrência \\
\hline Cienciometria & 4 & Formação do bibliotecário & 1 \\
\hline Competência & 4 & Formação profissional & 1 \\
\hline Documentação & 4 & $\begin{array}{l}\text { Formas e meios de } \\
\text { compartilhamento }\end{array}$ & 1 \\
\hline Educação à distância & 4 & Formato MARC & 1 \\
\hline Informação tecnológica & 4 & Função da biblioteca & 1 \\
\hline Lei de Lotka & 4 & $\begin{array}{l}\text { Fundações } \\
\text { de direito privado sem fins } \\
\text { lucrativos }\end{array}$ & 1 \\
\hline Memória & 4 & Gênero & 1 \\
\hline Periódico & 4 & Gerencialismo & 1 \\
\hline Política de informação & 4 & $\begin{array}{l}\text { Gerenciamento de informação na } \\
\text { web }\end{array}$ & 1 \\
\hline Pós-graduação & 4 & Gerenciamento de projetos & 1 \\
\hline Recuperação da informação & 4 & $\begin{array}{l}\text { Gerenciamento de } \\
\text { relacionamentos com clientes }\end{array}$ & 1 \\
\hline Repositorio institucional & 4 & $\begin{array}{l}\text { Gestão da informação e do } \\
\text { conhecimento }\end{array}$ & 1 \\
\hline Responsabilidade social & 4 & Gestão da qualidade & 1 \\
\hline Tecnologia da informação & 4 & Gestão da saúde pública & 1 \\
\hline Unidade de informação & 4 & $\begin{array}{l}\text { Gestão da segurança e saúde no } \\
\text { trabalho }\end{array}$ & 1 \\
\hline Webometria & 4 & Gestão de coleção & 1 \\
\hline Análise de conteúdo & 3 & Gestão de competências & 1 \\
\hline Análise de rede social & 3 & Gestão de operações de serviço & 1 \\
\hline Arquitetura da informação & 3 & $\begin{array}{l}\text { Gestão de pessoas por } \\
\text { competências }\end{array}$ & 1 \\
\hline Base de Dados & 3 & Gestão de projetos & 1 \\
\hline Bibliotecário escolar & 3 & Gestão de serviços bibliotecários & 1 \\
\hline Busca de informação & 3 & Gestão de serviços públicos & 1 \\
\hline Cidadania & 3 & Gestão do capital humano & 1 \\
\hline $\begin{array}{l}\text { Comportamento de busca de } \\
\text { informação }\end{array}$ & 3 & Gestão do capital intelectual & 1 \\
\hline Comportamento informacional & 3 & $\begin{array}{l}\text { Gestão do conhecimento em } \\
\text { universidades }\end{array}$ & 1 \\
\hline Conhecimento científico & 3 & Gestão e produção de sentidos & 1 \\
\hline Construção de conhecimento & 3 & Gestão estratégica da informação & 1 \\
\hline Cultura organizacional & 3 & Gestão estratégica de operações & 1 \\
\hline Informação e tecnologia & 3 & Gestão organizacional & 1 \\
\hline Informação estatística & 3 & Gestão por processos & 1 \\
\hline Informação estratégica & 3 & Gestão de conteúdos educativos & 1 \\
\hline Informação para negócios & 3 & Gestão documental & 1 \\
\hline Iniciativa de arquivos abertos & 3 & $\begin{array}{l}\text { Globalização de publicações } \\
\text { científicas }\end{array}$ & 1 \\
\hline Leitura & 3 & Globalização econômica & 1 \\
\hline Linguagem documentária & 3 & Grupo desfavorecidos & 1 \\
\hline Mercado de trabalho & 3 & Grupo focal & 1 \\
\hline Organização da informação & 3 & Grupos marginados & 1 \\
\hline Periódico científico eletrônico & 3 & Grupos minoritarios & 1 \\
\hline Periódico eletrônico & 3 & Grupo vulneráveis & 1 \\
\hline Políticas públicas de informação & 3 & Habilidades e competências & 1 \\
\hline
\end{tabular}




\begin{tabular}{|c|c|c|c|}
\hline Palavra-chave & Ocorrência & Palavra-chave & Ocorrência \\
\hline $\begin{array}{l}\text { Sistema de recuperação da } \\
\text { informação }\end{array}$ & 3 & Hábito de leitura & 1 \\
\hline Sociedade do conhecimento & 3 & Hierarquia informacional (DIKW) & 1 \\
\hline Software livre & 3 & Hipermídia & 1 \\
\hline Tecnologia & 3 & Hipertextualidade & 1 \\
\hline Tesauro & 3 & História & 1 \\
\hline Teses & 3 & História da documentação & 1 \\
\hline Teses e dissertações eletrônicas & 3 & História de aprendizagem & 1 \\
\hline Tomada de decisão & 3 & Homem & 1 \\
\hline Transferência de informação & 3 & Hortaliças & 1 \\
\hline Universidade & 3 & Identidade profissional & 1 \\
\hline Valor & 3 & Identidades afrodescendentes & 1 \\
\hline Vocabulario controlado & 3 & Identificação de autoria & 1 \\
\hline Web semântica & 3 & Imagem & 1 \\
\hline Acesso à informação & 2 & Imagem fotográfica & 1 \\
\hline Acesso à informação científica & 2 & Imagem profissional & 1 \\
\hline Acesso livre à informação & 2 & Impacto bibliográfico & 1 \\
\hline Agências de fomento & 2 & Impacto positivo e negativo & 1 \\
\hline Alfabetização digital & 2 & Incentivo a leitura & 1 \\
\hline Arquivo & 2 & Inclusão empresarial & 1 \\
\hline Arquivologia & 2 & Inclusão social & 1 \\
\hline Atuação profissional & 2 & Incubadoras tecnológicas & 1 \\
\hline $\begin{array}{l}\text { Biblioteca Digital de Teses e } \\
\text { Dissertações (BDTD) }\end{array}$ & 2 & Indexação automática & 1 \\
\hline Biblioteca pública & 2 & Indexação de filmes de ficção & 1 \\
\hline Bioprospecção & 2 & Indexação de vídeos & 1 \\
\hline Catalogação & 2 & Indexação semi-automática & 1 \\
\hline Cibercultura & 2 & Indexação sintagmática & 1 \\
\hline Cientista da informação & 2 & Indexador & 1 \\
\hline Classificação facetada & 2 & Indicadores científicos & 1 \\
\hline Co-autoria & 2 & $\begin{array}{l}\text { Indicadores de analfabetísmo } \\
\text { funcional }\end{array}$ & 1 \\
\hline $\begin{array}{l}\text { Compartilhamento da informação } \\
\text { e do conhecimento }\end{array}$ & 2 & Indicadores de inovação & 1 \\
\hline Competência profissional & 2 & Índice de dispersão & 1 \\
\hline Comportamento de busca & 2 & Índice de mensuração & 1 \\
\hline Comunicação & 2 & Indústria química & 1 \\
\hline $\begin{array}{l}\text { Comunicação integrada de } \\
\text { marketing }\end{array}$ & 2 & Informação científica e tecnológica & 1 \\
\hline Comunidades virtuais & 2 & Informação corporativa & 1 \\
\hline Conhecimento científico tácito & 2 & Informação do ambiente externo & 1 \\
\hline Controle & 2 & Informação e cidadania & 1 \\
\hline Criação de conhecimento & 2 & Informação empresarial & 1 \\
\hline Desenvolvimento de coleções & 2 & Informação no Mercosul & 1 \\
\hline Difusão & 2 & Informação para a indústria & 1 \\
\hline Digitalização & 2 & Informação pragmática & 1 \\
\hline Direito autoral & 2 & Informação pública & 1 \\
\hline
\end{tabular}




\begin{tabular}{|c|c|c|c|}
\hline Palavra-chave & Ocorrência & Palavra-chave & Ocorrência \\
\hline Disciplina & 2 & Informação registrada & 1 \\
\hline Discurso & 2 & Informação semântica & 1 \\
\hline Dispersão & 2 & Informação sintática & 1 \\
\hline Dissertação & 2 & Informação social & 1 \\
\hline Documentação audiovisual & 2 & Informetria matemática & 1 \\
\hline Documento & 2 & Infra-estrutura de informação & 1 \\
\hline Documento eletrônico & 2 & $\begin{array}{l}\text { Infra-estrutura de informação } \\
\text { científica }\end{array}$ & 1 \\
\hline Estereótipo & 2 & Inovação tecnológica & 1 \\
\hline Estudo de usuário & 2 & Inovação tecnológica empresarial & 1 \\
\hline Ética & 2 & Instituições bancárias & 1 \\
\hline Fotografia & 2 & Integração de sistemas & 1 \\
\hline Gestão & 2 & Inteligência coletiva & 1 \\
\hline Gestão de conteúdo & 2 & Inteligência de negócios & 1 \\
\hline Gestão de documentos & 2 & Inteligencia empresarial & 1 \\
\hline Gestão do conhecimento científico & 2 & Inteligência estratégica & 1 \\
\hline Governança & 2 & Intelligentsia galore & 1 \\
\hline Governo eletrônico & 2 & Interação social & 1 \\
\hline Hipertexto & 2 & Interações humanas & 1 \\
\hline História da ciência & 2 & Interações sociais & 1 \\
\hline História da Ciência da informação & 2 & Interatividade & 1 \\
\hline Identidade & 2 & $\begin{array}{l}\text { Interdisciplinaridade da Ciência da } \\
\text { Informação }\end{array}$ & 1 \\
\hline Identidade cultural & 2 & Interlink & 1 \\
\hline Indexação & 2 & Intermedialidade & 1 \\
\hline $\begin{array}{l}\text { Indicadores de ciência e } \\
\text { tecnologia }\end{array}$ & 2 & Internet na educação & 1 \\
\hline Indicadores de desempenho & 2 & Interoperabilidade & 1 \\
\hline Informação arquivística & 2 & \begin{tabular}{|l|} 
Intertextualidade \\
\end{tabular} & 1 \\
\hline Inovação & 2 & Inventário de coleções & 1 \\
\hline Institucionalização & 2 & Jesuítas & 1 \\
\hline Inteligência artificial & 2 & Jornalismo & 1 \\
\hline Inteligência organizacional & 2 & Legibilidade & 1 \\
\hline Interações & 2 & Legislação da informação & 1 \\
\hline Jornal & 2 & $\begin{array}{l}\text { Legitimação e legitimidade das } \\
\text { publicações eletrônicas }\end{array}$ & 1 \\
\hline Marketing & 2 & Lei de Price & 1 \\
\hline Marketing profissional & 2 & Lei do elitismo & 1 \\
\hline Mediação & 2 & Leitores & 1 \\
\hline Metodologia & 2 & Leitura como evento social & 1 \\
\hline Mineração de textos & 2 & Leitura feminina & 1 \\
\hline Necessidades de informação & 2 & Leitura hipertextual & 1 \\
\hline Padrões & 2 & Leitura informacional & 1 \\
\hline Patentes & 2 & Lematização & 1 \\
\hline Pesquisa & 2 & Letramento & 1 \\
\hline Pesquisa escolar & 2 & Letramento digital & 1 \\
\hline Políticas públicas & 2 & Letramento informacional & 1 \\
\hline Preservação digital & 2 & Liberdade leitora & 1 \\
\hline Processo decisório & 2 & Linguagem de indexação & 1 \\
\hline Promoção da informação & 2 & Línguas & 1 \\
\hline Regime de informação & 2 & Lingüística computacional & 1 \\
\hline
\end{tabular}




\begin{tabular}{|c|c|c|c|}
\hline Palavra-chave & Ocorrência & Palavra-chave & Ocorrência \\
\hline Representação & 2 & Linha brasileira & 1 \\
\hline Representação do conhecimento & 2 & Linha francesa & 1 \\
\hline $\begin{array}{l}\text { Requisitos funcionais para } \\
\text { registros bibliográficos (FRBR) }\end{array}$ & 2 & Link & 1 \\
\hline Segurança da informação & 2 & Literatura científica & 1 \\
\hline Semiótica & 2 & Literatura de enfermagem & 1 \\
\hline Serviço & 2 & Literatura infantil & 1 \\
\hline Serviço de informação & 2 & Manual de indexação & 1 \\
\hline Serviço de referência & 2 & Mapa conceitual & 1 \\
\hline Telecentro & 2 & Mapa temático & 1 \\
\hline Terminologia & 2 & Mapeamento de competências & 1 \\
\hline Trabalho & 2 & Marc21 & 1 \\
\hline Trabalho colaborativo & 2 & MarcOnt & 1 \\
\hline Tv digital & 2 & Marketing da informação & 1 \\
\hline Usabilidade & 2 & Marketing pessoal & 1 \\
\hline Uso & 2 & Mashup & 1 \\
\hline Web & 2 & Matemática & 1 \\
\hline Web 2.0 & 2 & Mecanismos de busca & 1 \\
\hline Web site & 2 & Mecanismos de regulação social & 1 \\
\hline Wiki & 2 & Mediação cultural & 1 \\
\hline $\mathrm{XML}$ & 2 & Mediação documental & 1 \\
\hline Z39.50 & 2 & Mediação informacional & 1 \\
\hline $\begin{array}{l}\text { 5S (societies, scenarios, spaces, } \\
\text { structures, streams) }\end{array}$ & 1 & Médiamétrie & 1 \\
\hline Abordagem cognitivista & 1 & Mediawiki & 1 \\
\hline Abordagem diferenciada & 1 & Melhores práticas & 1 \\
\hline Ação comunicativa & 1 & $\begin{array}{l}\text { Mestrado em Ciência da } \\
\text { Informação }\end{array}$ & 1 \\
\hline Ação cultural & 1 & Medida & 1 \\
\hline Acervo bibliográfico & 1 & Metadados & 1 \\
\hline Acervo fotográfico & 1 & Metadados científicos & 1 \\
\hline Acervos de filmes & 1 & Metadata standards & 1 \\
\hline Acessibilidade & 1 & Método de análise dialético & 1 \\
\hline $\begin{array}{l}\text { Acesso e democratização da } \\
\text { informação }\end{array}$ & 1 & Método indiciário & 1 \\
\hline $\begin{array}{l}\text { Acesso livre ao conhecimento } \\
\text { científico }\end{array}$ & 1 & Metodologia científica & 1 \\
\hline Adaptação & 1 & Metodologia de pesquisa & 1 \\
\hline Administração & 1 & Metodologia Just-In-Time & 1 \\
\hline Administração da informação & 1 & Metodologia Webquest & 1 \\
\hline Agenda digital & 1 & Métodos de análisis multivariable & 1 \\
\hline Agente histórico & 1 & Métodos quantitativos & 1 \\
\hline Alunos & 1 & $\begin{array}{l}\text { Micro e pequenas empresas } \\
\text { (MPEs) }\end{array}$ & 1 \\
\hline Alunos com deficiência & 1 & Migração de suportes & 1 \\
\hline Ambiente de biblioteca & 1 & Moda & 1 \\
\hline Ambiente de compartilhamento & 1 & Modelagem conceitual & 1 \\
\hline $\begin{array}{l}\text { Ambiente } \\
\text { Informacional Digital }\end{array}$ & 1 & $\begin{array}{l}\text { Modelo de gestão do } \\
\text { conhecimento científico }\end{array}$ & 1 \\
\hline Análise Co-link & 1 & Modelo de Informação & 1 \\
\hline
\end{tabular}




\begin{tabular}{|c|c|c|c|}
\hline Palavra-chave & Ocorrência & Palavra-chave & Ocorrência \\
\hline Análise da imagem fotográfica & 1 & $\begin{array}{l}\text { Modelo Gauss Poisson inverso } \\
\text { generalizado }\end{array}$ & 1 \\
\hline Análise de assunto & 1 & Modelo informacional & 1 \\
\hline Análise de conceitos & 1 & Modelo organizacional & 1 \\
\hline Análise de domínio & 1 & Modelo Poisson lognormal & 1 \\
\hline Análise de filmes de ficção & 1 & $\begin{array}{l}\text { Modelos de comportamento de } \\
\text { busca de informação }\end{array}$ & 1 \\
\hline Análise de perfil profissional & 1 & Modelos de negócio & 1 \\
\hline Análise de políticas públicas & 1 & $\begin{array}{l}\text { Modelos de negócios de editores } \\
\text { científicos }\end{array}$ & 1 \\
\hline Análise do discurso & 1 & Modelos de requisitos & 1 \\
\hline Análise Documentária & 1 & Modernidade & 1 \\
\hline Análise facetada & 1 & $\begin{array}{l}\text { Moderno profissional da } \\
\text { Informação }\end{array}$ & 1 \\
\hline Análise setorial & 1 & $\begin{array}{l}\text { Monitoramento do ambiente } \\
\text { competitivo }\end{array}$ & 1 \\
\hline $\begin{array}{l}\text { Análise } \\
\text { bibliométrica }\end{array}$ & 1 & $\begin{array}{l}\text { Monitoramento do ambiente } \\
\text { externo }\end{array}$ & 1 \\
\hline Antiquários e trabalho & 1 & Monumento & 1 \\
\hline Aprendizado & 1 & Motivação para compartilhar & 1 \\
\hline Aprendizado contínuo & 1 & Mots & 1 \\
\hline $\begin{array}{l}\text { Aprendizagem baseada no } \\
\text { questionamento }\end{array}$ & 1 & Movimentos sociais & 1 \\
\hline Apropriação dos saberes & 1 & Mudança organizacional & 1 \\
\hline Arqueologia do saber & 1 & Mulher & 1 \\
\hline $\begin{array}{l}\text { Arquitetura de Tecnologia } \\
\text { Informação }\end{array}$ & 1 & Multicritério & 1 \\
\hline Arquivo digital & 1 & $\begin{array}{l}\text { Múltiplos papéis do profissional da } \\
\text { informação }\end{array}$ & 1 \\
\hline Arquivo e esfera pública & 1 & $\begin{array}{l}\text { Múltiplos papéis do profissional de } \\
\mathrm{RH}\end{array}$ & 1 \\
\hline Arquivo escolar & 1 & Multivocalidade & 1 \\
\hline Arquivos da ditadura militar & 1 & Muséométrie & 1 \\
\hline Arquivos de televisão & 1 & Narrativas & 1 \\
\hline Arranjo produtivo local & 1 & $\begin{array}{l}\text { Narrativas de histórias } \\
\text { organizacionais }\end{array}$ & 1 \\
\hline Artigo científico & 1 & Nome & 1 \\
\hline Artigo de periódico & 1 & Normalização arquivística & 1 \\
\hline Atividades de biblioteca & 1 & Normalização técnica & 1 \\
\hline Autoria & 1 & Normativa & 1 \\
\hline Autoria coletiva & 1 & Nova gestão pública & 1 \\
\hline Autoria múltipla & 1 & Novas atitudes dos autores & 1 \\
\hline Autoria ontológica & 1 & Obras raras & 1 \\
\hline Avaliação da produção científica & 1 & Ontologia da linguagem & 1 \\
\hline Avaliação da qualidade & 1 & Ordenação & 1 \\
\hline Avaliação de acervos & 1 & $\begin{array}{l}\text { Organização da Informação } \\
\text { científica e tecnológica }\end{array}$ & 1 \\
\hline Avaliação de fontes de informação & 1 & Organização do saber & 1 \\
\hline Avaliação de portais & 1 & $\begin{array}{l}\text { Organização fundamentada na } \\
\text { informação e no conhecimento }\end{array}$ & 1 \\
\hline
\end{tabular}




\begin{tabular}{|c|c|c|c|}
\hline Palavra-chave & Ocorrência & Palavra-chave & Ocorrência \\
\hline Avaliação de produção científica & 1 & Organizações & 1 \\
\hline $\begin{array}{l}\text { Avaliação de serviços de } \\
\text { bibliotecas }\end{array}$ & 1 & $\begin{array}{l}\text { Organizações da era do } \\
\text { conhecimento }\end{array}$ & 1 \\
\hline Avaliação de sites & 1 & Organizações em rede & 1 \\
\hline Avaliação de software & 1 & $\begin{array}{l}\text { Padrões de comportamento } \\
\text { informacional }\end{array}$ & 1 \\
\hline Avaliação pelos pares & 1 & Padrões de metadados & 1 \\
\hline Axiologia e biblioteconomia & 1 & Padrões e regras & 1 \\
\hline Barreiras no compartilhamento & 1 & $\begin{array}{l}\text { Padronização e representação da } \\
\text { informação }\end{array}$ & 1 \\
\hline Bens de consumo & 1 & Paradigma técnico-econômico & 1 \\
\hline $\begin{array}{l}\text { Bens de consumo de uso } \\
\text { duradouro }\end{array}$ & 1 & Parques tecnológicos & 1 \\
\hline Bens permanentes & 1 & Patentes acadêmicas & 1 \\
\hline Biblioteca 2.0 & 1 & Patrimônio & 1 \\
\hline $\begin{array}{l}\text { Biblioteca digital de teses e } \\
\text { dissertações em rede }\end{array}$ & 1 & Patrimônio arqueológico & 1 \\
\hline Biblioteca digital educativa & 1 & Patrimônio histórico & 1 \\
\hline Biblioteca eletrônica & 1 & Pensar reconstrutivo & 1 \\
\hline Biblioteca universal & 1 & Pequenas e médias empresas & 1 \\
\hline Bibliotecário humanista & 1 & $\begin{array}{l}\text { Percepção da qualidade da } \\
\text { informação }\end{array}$ & 1 \\
\hline Biblioteconomia brasileira & 1 & Perfil de usuários & 1 \\
\hline Biblioterapia & 1 & Perfil do bibliotecário & 1 \\
\hline Biologia molecular e biotecnologia & 1 & Perfil do profissional bibliotecário & 1 \\
\hline Blog & 1 & Performance & 1 \\
\hline Bradford & 1 & Periódico científico brasileiro & 1 \\
\hline Burocracia & 1 & Periódicos de biblioteconomia & 1 \\
\hline Busca e uso de informação & 1 & Periódicos nacionais & 1 \\
\hline Cadeia produtiva & 1 & $\begin{array}{l}\text { Perspectivas dos bons } \\
\text { professores }\end{array}$ & 1 \\
\hline Call center & 1 & Pesquisa agropecuária brasileira & 1 \\
\hline Campo da Ciência da Informação & 1 & Pesquisa e desenvolvimento & 1 \\
\hline $\begin{array}{l}\text { Canais de comunicação da } \\
\text { informação }\end{array}$ & 1 & $\begin{array}{l}\text { Pesquisa em Ciência da } \\
\text { Informação }\end{array}$ & 1 \\
\hline Capacitação acadêmica & 1 & Pesquisa em informação & 1 \\
\hline Capital competitivo & 1 & Pesquisa industrial & 1 \\
\hline Capital de clientela & 1 & Pesquisa qualitativa & 1 \\
\hline Capital estrutural & 1 & Pesquisador juvenil & 1 \\
\hline Capital social & 1 & Planejamento governamental & 1 \\
\hline Cartes & 1 & Plano nacional do livro e leitura & 1 \\
\hline Catalogação automatizada & 1 & Plasma & 1 \\
\hline Catalogação cooperativa & 1 & Política & 1 \\
\hline Catálogo de dados & 1 & Política de indexação & 1 \\
\hline Categorias & 1 & $\begin{array}{l}\text { Política de informação e } \\
\text { governança }\end{array}$ & 1 \\
\hline Categorização & 1 & Política editorial & 1 \\
\hline Cenário da leitura no Brasil & 1 & $\begin{array}{l}\text { Políticas de segurança da } \\
\text { informação }\end{array}$ & 1 \\
\hline $\begin{array}{l}\text { Centros de recursos para o ensino } \\
\text { e aprendizagem }\end{array}$ & 1 & Ponto de acesso pessoal & 1 \\
\hline
\end{tabular}




\begin{tabular}{|c|c|c|c|}
\hline Palavra-chave & Ocorrência & Palavra-chave & Ocorrência \\
\hline Chat & 1 & Pontos cegos & 1 \\
\hline Chatterbot & 1 & Portais & 1 \\
\hline Chave & 1 & $\begin{array}{l}\text { Portais de informações e serviços } \\
\text { públicos }\end{array}$ & 1 \\
\hline Choque cultural & 1 & Portais de periódicos científicos & 1 \\
\hline Cibermetria & 1 & Portal corporativo & 1 \\
\hline Ciclo de IC & 1 & $\begin{array}{l}\text { Pós-graduação em ciência da } \\
\text { informação }\end{array}$ & 1 \\
\hline Ciclo de inteligência & 1 & Pós-modernidade & 1 \\
\hline Ciclo de vida das organizações & 1 & Pragmática & 1 \\
\hline Ciência administrativa & 1 & Prática arquivística & 1 \\
\hline Ciência cognitiva & 1 & $\begin{array}{l}\text { Prática de ensino de política de } \\
\text { indexação }\end{array}$ & 1 \\
\hline Ciência da Informação brasileira & 1 & Prática de pesquisa & 1 \\
\hline Ciência da Informação na Rússia & 1 & Prática informacional & 1 \\
\hline $\begin{array}{l}\text { Ciência da Informação na União } \\
\text { soviética }\end{array}$ & 1 & Predicação sintático-semântica & 1 \\
\hline Ciência e tecnologia & 1 & Preservação de acervos & 1 \\
\hline Ciências da Saúde & 1 & Princípio monográfico & 1 \\
\hline Cinema brasileiro & 1 & $\begin{array}{l}\text { Processamento de linguagem } \\
\text { natural }\end{array}$ & 1 \\
\hline Cinematografía & 1 & Processo de busca de informação & 1 \\
\hline Círculo de Roqueplo & 1 & Processo de comunicação & 1 \\
\hline Citação em espanhol & 1 & $\begin{array}{l}\text { Processo de desenvolvimento de } \\
\text { produtos }\end{array}$ & 1 \\
\hline Classificação & 1 & $\begin{array}{l}\text { Processo de ensino- } \\
\text { aprendizagem }\end{array}$ & 1 \\
\hline Classificação filosófica & 1 & Processo gerencial & 1 \\
\hline $\begin{array}{l}\text { Classificação Brasileira de } \\
\text { Ocupações }\end{array}$ & 1 & $\begin{array}{l}\text { Processos de gerenciamento da } \\
\text { informação }\end{array}$ & 1 \\
\hline Classificação Contábil & 1 & Processos informacionais & 1 \\
\hline Classificação decimal & 1 & Produção colaborativa & 1 \\
\hline Classificação documenta & 1 & Produção do conhecimento & 1 \\
\hline Classificação industrial & 1 & Produtores orgânicos & 1 \\
\hline Clientes & 1 & Produtos orgânicos & 1 \\
\hline Código aberto & 1 & Produtos químicos & 1 \\
\hline Coerência & 1 & Professor & 1 \\
\hline Coesão & 1 & Professor documentalista & 1 \\
\hline Cognição & 1 & Profissionais de IC & 1 \\
\hline Cognição situada & 1 & Profissionalização & 1 \\
\hline Colaboração científica & 1 & Programas de entretenimento & 1 \\
\hline Coleção de obras raras & 1 & Programas de pesquisa & 1 \\
\hline Colégios invisíveis & 1 & Projeto de pesquisa & 1 \\
\hline Colégios virtuais & 1 & Propriedade intelectual & 1 \\
\hline Coleta de dados & 1 & Proteção ao conhecimento & 1 \\
\hline Comércio digital & 1 & Protocolos de comunicação & 1 \\
\hline Compartilhamento & 1 & Publicação científica & 1 \\
\hline Competências & 1 & Publicação digital & 1 \\
\hline $\begin{array}{l}\text { Competências dos Profissionais } \\
\text { da Informação }\end{array}$ & 1 & Qualificação profissional & 1 \\
\hline Competências organizacionais & 1 & Question point & 1 \\
\hline
\end{tabular}




\begin{tabular}{|c|c|c|c|}
\hline Palavra-chave & Ocorrência & Palavra-chave & Ocorrência \\
\hline Competição justa & 1 & Racionalidade & 1 \\
\hline Complex adaptive systems & 1 & Razão & 1 \\
\hline Complexidade & 1 & Recepção & 1 \\
\hline Complexidade tecnológica & 1 & Reconhecimento social & 1 \\
\hline $\begin{array}{l}\text { Composto de comunicação de } \\
\text { marketing }\end{array}$ & 1 & $\begin{array}{l}\text { Recuperação do conteúdo } \\
\text { audiovisual }\end{array}$ & 1 \\
\hline $\begin{array}{l}\text { Comunicação científica de acesso } \\
\text { livre }\end{array}$ & 1 & Recurso trabalhista & 1 \\
\hline Comunicação científica eletrônica & 1 & Recursos eletrônicos & 1 \\
\hline Comunicação científica formal & 1 & Redação científica & 1 \\
\hline $\begin{array}{l}\text { Comunicação científica } \\
\text { intercultural }\end{array}$ & 1 & Rede de colaboração científica & 1 \\
\hline $\begin{array}{l}\text { Comunicação científica } \\
\text { semiformal }\end{array}$ & 1 & Redes cognitivas & 1 \\
\hline Comunicação da informação & 1 & Redes de co-autoria & 1 \\
\hline Comunicação de marketing & 1 & Redes de pesquisa & 1 \\
\hline Comunicação eletrônica & 1 & Redes de relacionamento & 1 \\
\hline Comunicação intercultural & 1 & Redes interdisciplinares & 1 \\
\hline Comunicação organizacional & 1 & Redes neurais & 1 \\
\hline Comunidade científica & 1 & Redes neurais ART & 1 \\
\hline Comunidade científica brasileira & 1 & Redes neurais artificiais & 1 \\
\hline Comunidade de prática & 1 & Redes políticas & 1 \\
\hline Comunidades discursivas & 1 & Referência digital & 1 \\
\hline $\begin{array}{l}\text { Conceitos de Ciência da } \\
\text { Informação }\end{array}$ & 1 & Referência interna & 1 \\
\hline Conceitos de Informação & 1 & Registro contábil & 1 \\
\hline Confiabilidade & 1 & Registros electrónicos & 1 \\
\hline Configurações em rede & 1 & Regulação & 1 \\
\hline $\begin{array}{l}\text { Congressos e comunicação } \\
\text { científica }\end{array}$ & 1 & Relação universidade-inovação & 1 \\
\hline Conhecimento emancipatório & 1 & Relações conceituais & 1 \\
\hline Conhecimento empresarial & 1 & Relatório financeiro & 1 \\
\hline Conhecimento organizacional & 1 & Repositórios digitais & 1 \\
\hline Connectedness & 1 & Representação descritiva & 1 \\
\hline Consciência & 1 & $\begin{array}{l}\text { Representação documentária de } \\
\text { filmes de ficção }\end{array}$ & 1 \\
\hline Conservação de livros raros & 1 & Representações & 1 \\
\hline Consórcio de bibliotecas & 1 & Responsabilidade do autor & 1 \\
\hline Consórcio ProBE & 1 & Responsabilidade do editor & 1 \\
\hline Construção de informação & 1 & Responsabilidade do referee & 1 \\
\hline Construção de ontologias & 1 & Responsabilidade ética & 1 \\
\hline $\begin{array}{l}\text { Construção de vocabulários } \\
\text { controlados }\end{array}$ & 1 & Resumo & 1 \\
\hline Consultores empresariais & 1 & Revistas & 1 \\
\hline Contação de histórias & 1 & Revistas Científicas & 1 \\
\hline Contemporaneidade & 1 & $\begin{array}{l}\text { Ritmo de obsolescência da } \\
\text { literatura }\end{array}$ & 1 \\
\hline Conteúdos interativos & 1 & Rizoma & 1 \\
\hline Contra-hegemonia & 1 & Rss & 1 \\
\hline Controle de acesso & 1 & Semântica & 1 \\
\hline Convergência tecnológica & 1 & Sentido & 1 \\
\hline
\end{tabular}




\begin{tabular}{|c|c|c|c|}
\hline Palavra-chave & Ocorrência & Palavra-chave & Ocorrência \\
\hline Conversações & 1 & Serviço de referência virtual & 1 \\
\hline Conversão informacional & 1 & Serviços bibliotecarios & 1 \\
\hline Conversões do conhecimento & 1 & $\begin{array}{l}\text { Serviços de informação } \\
\text { tecnológica }\end{array}$ & 1 \\
\hline Cooperação bibliotecária & 1 & Simulação computacional & 1 \\
\hline Cooperação científica & 1 & Sindicato & 1 \\
\hline Cooperação empresarial & 1 & Sintagma nominal & 1 \\
\hline Cooperação internacional & 1 & Sistema analítico-sintético & 1 \\
\hline Coordenação interorganizacional & 1 & Sistema de informação estatística & 1 \\
\hline Creative Commons & 1 & $\begin{array}{l}\text { Sistema de inventário } \\
\text { automatizado }\end{array}$ & 1 \\
\hline Crescimento exponencial & 1 & Sistema estatístico & 1 \\
\hline Criação de informação & 1 & Sistema KANBAN de produção & 1 \\
\hline Criação e repasse de tecnologias & 1 & Sistemas abertos & 1 \\
\hline Crise dos periódicos & 1 & Sistemas adaptativos & 1 \\
\hline Crítica & 1 & \begin{tabular}{|l|} 
Sistemas de informação \\
geográfica
\end{tabular} & 1 \\
\hline Criticismo & 1 & Sistemas de informação web & 1 \\
\hline Cultura & 1 & $\begin{array}{l}\text { Sistemas de recuperação da } \\
\text { informação visual }\end{array}$ & 1 \\
\hline Cultura amazônica & 1 & Site & 1 \\
\hline Cultura da publicação eletrônica & 1 & $\begin{array}{l}\text { Sites de clubes de futebol da } \\
\text { Argentina }\end{array}$ & 1 \\
\hline Cultura digital & 1 & Social software & 1 \\
\hline Cultura docente & 1 & Socialização do conhecimento & 1 \\
\hline Cultura informacional & 1 & $\begin{array}{l}\text { Sociedade da informação e do } \\
\text { conhecimento }\end{array}$ & 1 \\
\hline Cultura material & 1 & Sociedade inclusiva & 1 \\
\hline Curricula & 1 & Sociologia da ciência & 1 \\
\hline $\begin{array}{l}\text { Currículo de cursos de graduação } \\
\text { em biblioteconomia }\end{array}$ & 1 & Software & 1 \\
\hline Curso de Arquivologia & 1 & Softwares de tesauros & 1 \\
\hline Dados estatísticos & 1 & SRU & 1 \\
\hline Dalcídio Jurandir & 1 & SRW & 1 \\
\hline Decisão & 1 & Streaming media & 1 \\
\hline Decisão estratégica & 1 & Sujeito & 1 \\
\hline Demanda tecnológica & 1 & Summarizer & 1 \\
\hline Democracia & 1 & Tagging & 1 \\
\hline Densidade dos artigos & 1 & Tecnologia e Informação & 1 \\
\hline Descarte & 1 & Tecnologias digitais & 1 \\
\hline $\begin{array}{l}\text { Descoberta de conhecimento em } \\
\text { texto (DCT) }\end{array}$ & 1 & TEDE & 1 \\
\hline Descrição arquivística & 1 & Televisão & 1 \\
\hline Desempenho organizacional & 1 & $\begin{array}{l}\text { Tematização da imagem } \\
\text { fotográfica }\end{array}$ & 1 \\
\hline $\begin{array}{l}\text { Desenvolvimento de } \\
\text { competências }\end{array}$ & 1 & Teoria da classificação facetada & 1 \\
\hline Desenvolvimento de equipes & 1 & Teoria ator-rede & 1 \\
\hline $\begin{array}{l}\text { Desenvolvimento de sistema de } \\
\text { informação }\end{array}$ & 1 & $\begin{array}{l}\text { Teoria comunicativa da } \\
\text { terminologia }\end{array}$ & 1 \\
\hline
\end{tabular}




\begin{tabular}{|c|c|c|c|}
\hline Palavra-chave & Ocorrência & Palavra-chave & Ocorrência \\
\hline Desenvolvimento sustentável & 1 & Teoria crítica & 1 \\
\hline Design & 1 & Teoria da Ciência da Informação & 1 \\
\hline Desintermediação da informação & 1 & Teoria da contingência & 1 \\
\hline Difusão de informações & 1 & Teoria da firma & 1 \\
\hline $\begin{array}{l}\text { Digitalização de documentos } \\
\text { iconográficos }\end{array}$ & 1 & Teoria da interpretação & 1 \\
\hline Dimensões da qualidade & 1 & Teoria da jurisdição & 1 \\
\hline Diretrizes de biblioteca & 1 & Teoria da ressonância adaptativa & 1 \\
\hline Discurso ético & 1 & Terceiro setor & 1 \\
\hline Dispositivo documentário & 1 & Tesauro conceitual & 1 \\
\hline Disseminação & 1 & Tesauro eletrônico & 1 \\
\hline Disseminação de dados & 1 & Thesaurus & 1 \\
\hline $\begin{array}{l}\text { Distribuição de poder inverso } \\
\text { generalizado }\end{array}$ & 1 & Tombamento & 1 \\
\hline Docência & 1 & Trabalho com projetos & 1 \\
\hline Docente & 1 & Trabalho de informação & 1 \\
\hline Documentação jurídica & 1 & Trajetória & 1 \\
\hline Documento arquivístico & 1 & Transductores de estado-finito & 1 \\
\hline Documento arquivístico eletrônico & 1 & Travestis & 1 \\
\hline Documentos acadêmicos & 1 & Turismo & 1 \\
\hline Documentos digitais & 1 & Tv & 1 \\
\hline E-ciência & 1 & Tv universitária & 1 \\
\hline Economia brasileira & 1 & Unidade de inteligência & 1 \\
\hline Economia Política & 1 & $\begin{array}{l}\text { Unidade de negócio em } \\
\text { informação }\end{array}$ & 1 \\
\hline Editoras universitárias & 1 & Unidade terminológica complexa & 1 \\
\hline Educação & 1 & $\begin{array}{l}\text { Unidades de informação com } \\
\text { imagem em movimento }\end{array}$ & 1 \\
\hline Educação continuada & 1 & Unificação de termos & 1 \\
\hline Educação Física & 1 & Uniformização de valores & 1 \\
\hline $\begin{array}{l}\text { Educação para a competência } \\
\text { informacional }\end{array}$ & 1 & Uso cognitivo da informação & 1 \\
\hline E-governo & 1 & Uso da informação & 1 \\
\hline Egressos & 1 & Usuário & 1 \\
\hline E-LIS & 1 & Usuário de informação estatística & 1 \\
\hline Embrapa & 1 & Usuários de informação & 1 \\
\hline Emigração portuguesa & 1 & Usuários vulneráveis de biblioteca & 1 \\
\hline Empreendedores & 1 & Utopias planetárias & 1 \\
\hline Empresa brasileira & 1 & Valoração contingente & 1 \\
\hline Empresa de base tecnológica & 1 & Valorização profissional & 1 \\
\hline $\begin{array}{l}\text { Empresa de representação } \\
\text { comercial de base industrial }\end{array}$ & 1 & Varejo & 1 \\
\hline Empresa Júnior & 1 & Vazamento do conhecimento & 1 \\
\hline Empresas brasileiras & 1 & Videoconferência & 1 \\
\hline Empresas de pequeno porte & 1 & Visibilidade científica & 1 \\
\hline Empresas prestadoras de serviço & 1 & Visibilidade social & 1 \\
\hline Enfermagem & 1 & Web colaborativa & 1 \\
\hline Engenharia civil & 1 & XBRL & 1 \\
\hline Ensino & 1 & & \\
\hline
\end{tabular}

